\title{
An Historical Survey of the Development of the Baroque Solo Keyboard Suite in France, England, and Germany
}

\author{
Robert Eric Armstrong \\ West Virginia University
}

Follow this and additional works at: https://researchrepository.wvu.edu/etd

\section{Recommended Citation}

Armstrong, Robert Eric, "An Historical Survey of the Development of the Baroque Solo Keyboard Suite in France, England, and Germany" (2011). Graduate Theses, Dissertations, and Problem Reports. 3023. https://researchrepository.wvu.edu/etd/3023

This Dissertation is protected by copyright and/or related rights. It has been brought to you by the The Research Repository @ WVU with permission from the rights-holder(s). You are free to use this Dissertation in any way that is permitted by the copyright and related rights legislation that applies to your use. For other uses you must obtain permission from the rights-holder(s) directly, unless additional rights are indicated by a Creative Commons license in the record and/ or on the work itself. This Dissertation has been accepted for inclusion in WVU Graduate Theses, Dissertations, and Problem Reports collection by an authorized administrator of The Research Repository @ WVU. For more information, please contact researchrepository@mail.wvu.edu. 
An Historical Survey of the Development of the Baroque Solo Keyboard Suite in France, England, and Germany

\title{
Robert Eric Armstrong
}

Research Project submitted to the

College of Creative Arts

at West Virginia University

in partial fulfillment of the requirements

for the degree of

Doctor of Musical Arts

In

Piano Performance

\author{
Peter Amstutz, D.M.A., Chair and Research Advisor \\ James Miltenberger, D.M.A. \\ William Haller, D.M.A. \\ Keith Jackson, D.M.A. \\ Mark Tauger, Ph.D. \\ Division of Music
}

\section{Morgantown, West Virginia 2011}

Keywords: Keyboard, Suite, Harpsichord, Clavichord, Johann Sebastian Bach, Baroque Music 


\section{ABSTRACT \\ An Historical Survey of the Development of the Baroque Solo Keyboard Suite in France, England, and Germany}

\section{Robert Eric Armstrong}

For over one hundred years during the Baroque Era, the suite was one of the most prominent genres in keyboard composition, and virtually every Baroque keyboard composer of significance from France, England, and Germany contributed to its propagation. While each of these countries developed its own stylistic approach to suite composition, it is also important to consider the ways in which these countries influenced each other and appropriated various aspects of one another's handling of the genre.

The Baroque keyboard suite represents the first large-scale keyboard genre to reflect a high degree of stylistic cross-fertilization between major European regions and beyond. Whether through a composer's individual travels, the transference of musical trends from one royal court to another, or the dissemination of manuscripts and printed collections, the suite was made to absorb any number of structural and characteristic influences throughout its development.

Individual keyboard dances and dance pairs, such as the pavane and galliard, had been in use throughout Renaissance- and Early-Baroque-Era Europe, but the suite served as an umbrella under which to gather a collection of these dances whose origins might lie as far away as the New World. As the Baroque Era progressed, the overall loose and highly flexible structural construction of the French made a lasting impression on composers in England and Germany, while the refined and tasteful compositions of John Locke and Henry Purcell in England made a skillful (if limited) contribution to music on the Continent. Froberger and his German compatriots then created a more rigid "core" of dances that absorbed many French musical concepts but also added a greater degree of German contrapuntal refinement.

Lastly, there are the works of Johann Sebastian Bach, which are arguably the crowning achievement of Late-Baroque keyboard suite composition. Bach was able to absorb the best of what had artistically taken place before him and employ it in his English Suites, French Suites, Partitas, and numerous other suite compositions. Influences and characteristics described in almost every section of the following chapters on France, England, and Germany may be found in Bach's works, and his suites serve as a brilliant summary of an era that for all practical purposes concluded with his death. 


\section{Table of Contents}

\section{CHAPTERS}

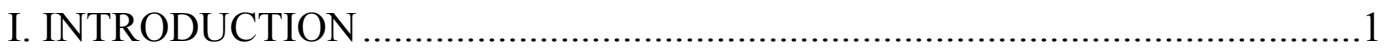

II. REVIEW OF RELATED LITERATURE ..............................................

III. THE ORIGINS OF THE KEYBOARD SUITE AND ITS PRIMARY CHARACTERISTICS ....................................................9

IV. THE KEYBOARD DANCES ........................................................... 16

V. THE FRENCH KEYBOARD SUITE.....................................................51

VI. THE ENGLISH KEYBOARD SUITE ................................................. 72

VII. THE GERMAN KEYBOARD SUITE …...............................................81

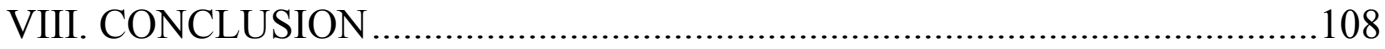

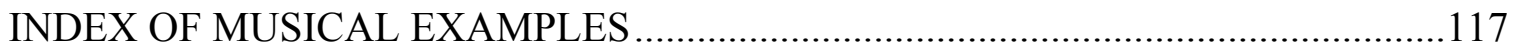

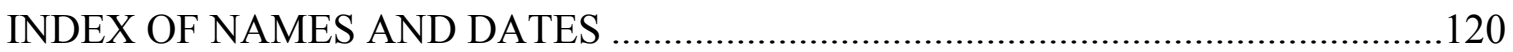

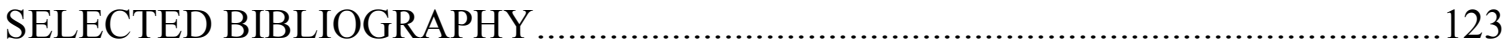




\section{Chapter I}

\section{Introduction}

The roots of the stylized keyboard suite date back to the $16^{\text {th }}$ Century. Since its inception and full acceptance as a viable medium for presenting keyboard music to the public in the mid- $17^{\text {th }}$ Century, the keyboard suite has been a highly respected artistic genre for composers of Western art music. Especially important to keyboard suite development were the innovations of the highly influential Italian composer, Girolamo Frescobaldi (1583-1643), who was the teacher of Johann Jakob Froberger (1616-1667), the first major contributor to the keyboard suite in Germany. Keyboard suites were also composed by European masters such as Henry Purcell (1659-1695), François Couperin (1668-1733), Johann Sebastian Bach (1685-1750), George Frideric Handel (1685-1759), and many others.

The overall purpose of this research project is to trace the development of the keyboard suite in France, England, and Germany from the mid-16 ${ }^{\text {th }}$ Century through the conclusion of the Baroque Era (c.1750). No surviving keyboard suites date from the $16^{\text {th }}$ Century, but a precursor, the lute suite, did begin its development at the time, along with many of the dance forms that eventually came to be incorporated into keyboard suites. In fact, the first suites for keyboard were actually intabulations of lute suites. ${ }^{1}$

During this time frame, by far the most significant output of suites comes from France, England, and Germany. Other countries in Europe have been omitted from discussion in this paper because their production of keyboard suites was either minimal

\footnotetext{
${ }^{1}$ Caldwell, J. "Sources of Keyboard Music to 1660," The New Grove Dictionary of Music and Musicians. Ed. by L. Macy. (Accessed 11/14/07) http://www.newgrovemusic.com.
} 
or nonexistent. Italy, for example, was home to the aforementioned Frescobaldi, who wrote numerous individual keyboard dances called corrente, ciaccona, passacaglia, balletto, and capriccio, but did not group these dances together as suites. It was up to Frescobaldi's students and followers in other countries to take these stylized dance forms and make them into suites. Otherwise, the only Italian Baroque composers I have been able to locate who actually wrote keyboard suites are Bernardo Pasquini (1637-1710) and Giovanni Battista Draghi (1640-1708). ${ }^{2}$ Incidentally, Draghi spent the bulk of his creative life in England and followed English compositional trends. I shall discuss his contributions in the chapter dealing with England.

There are no surviving keyboard suites to be found coming from Baroque Spanish composers despite the fact that musical characteristics stemming from Hispanic cultures made their way into the keyboard suites of composers from France, England, and Germany. Lastly, from The Netherlands I have been able to locate only one composer who contributed to the keyboard suite, Pieter Bustijn (1649-1729). ${ }^{3}$

In Chapter II, I shall review the current state of research literature about the keyboard suite. In Chapter III, I shall offer a fuller discussion of its origins leading up to the development of the suite as a general form and the "classical" suite as a fixed form. Chapter III also provides the reader with a greater understanding of the keyboard suite's structure and primary characteristics. In Chapter IV, I shall discuss the numerous dances and dance forms that have been used in suites, along with their stylistic characteristics, and historical backgrounds.

\footnotetext{
${ }^{2}$ Apel, W. The History of Keyboard Music to 1700. Trans. by H. Tischler. (Bloomington: Indiana University Press, 1972), 694-697.

${ }^{3}$ Apel, 768.
} 
As mentioned above, the three countries to provide the greatest contributions to Baroque keyboard suite development and repertoire were France, England, and Germany; a chapter is devoted to each of these countries with emphasis on their most significant composers. A brief conclusion is followed by an index of musical examples and an additional index of names and dates used in this dissertation.

My intention in this research project is to assist the reader in arriving at a fuller understanding of the development of a very important genre in keyboard music. Not only shall we examine the contributions of some of the world's most famous composers, but also we shall uncover the contributions of composers whose works have unjustly lapsed into obscurity and are worthy of further investigation. 


\section{Chapter II}

\section{Review of Related Literature}

The keyboard suite as a genre is addressed in numerous keyboard-literature textbooks, but rarely with a level of detail that is useful to a project such as this. As a rule, these books aim to cover all major genres and composers of keyboard literature over a large span of time without paying undue attention to any one of them. Nonetheless, a few of these books provide valuable information that not only assists the reader in understanding the genre, but also leads to further useful investigations. A small list of these books includes, but is not limited to:

- S. Gordon. A History of Keyboard Literature: Music for the Piano and Its Forerunners. ${ }^{4}$

- F. E. Kirby. Music for Piano: A Short History. ${ }^{5}$

- A. Silbiger. Keyboard Music before $1700 .^{6}$

- $\quad$ R. Marshall. Eighteenth-Century Keyboard Music. ${ }^{7}$

- J. Gillespie. Five Centuries of Keyboard Music. ${ }^{8}$

- W. Apel. The History of Keyboard Music to $1700 .^{9}$

From among these published books, those by Silbiger, Marshall, Apel, and

Gordon have proven to be the most useful for this project. The editorial contributions of

\footnotetext{
${ }^{4}$ Gordon, S. A History of Keyboard Literature: Music for the Piano and Its Forerunners. (New York: Schirmer Books, 1996).

${ }^{5}$ Kirby, F. E. Music for Piano: A Short History. (Portland, Oregon: Amadeus Press, 1995).

${ }^{6}$ Silbiger, A. Ed. Keyboard Music Before 1700. (New York: Routledge, 2004).

${ }^{7}$ Marshall, R. Ed. Eighteenth-Century Keyboard Music. (New York: Schirmer, 1994).

${ }^{8}$ Gillespie, J. Five Centuries of Keyboard Music. (New York: Dover Publications Inc., 1965).

${ }^{9}$ Apel, W. The History of Keyboard Music to 1700. Trans. by H. Tischler. (Bloomington: Indiana University Press, 1972).
} 
Silbiger and Marshall belong to a series of books entitled The Routledge Studies in Musical Genres, under the overall editorship of R. Larry Todd. The extended coverage presented by a series of books assists in providing a thorough understanding of the development of the genre. Chapters dealing with the history of keyboard music in each major region of continental Europe and England allow for a relatively complete understanding of the contributions made by that region's most prominent composers without having to resort to books dealing with only one composer at a time. The primary drawback to this series is that many different authors have contributed to the project, creating a lack of consistency in terms of writing style and overall academic approach.

Apel's contribution to the scholarship of Baroque keyboard music cannot be overestimated. Despite being published in 1972, The History of Keyboard Music to $1700^{10}$ remains the definitive and exhaustive guide to research in this field and provides a wealth of information about the development of the keyboard suite throughout $17^{\text {th }}$ Century Europe. Apel also discusses music for all keyboard instruments in use at the time, including harpsichord, clavichord, and organ.

While Gordon's keyboard repertoire book, A History of Keyboard Literature: Music for the Piano and Its Forerunners, ${ }^{11}$ is essentially an historical survey of the repertoire in its entirety, the section dealing with Handel and Bach is particularly helpful. The keyboard contributions of these composers (especially Bach) are so significant that the process of distilling the extensive quantity of information about them into this research project is difficult at best. Gordon's concise and straightforward approach to these two composers was the strongest that I came across.

\footnotetext{
${ }^{10}$ Apel.

${ }^{11}$ Gordon.
} 
I have also selected a few works from among an extensive list of theses and dissertations about the history and development of the keyboard suite that adhere to a high level of musical insightfulness and scholarly approach:

- D. Fuller. "Eighteenth-Century French Harpsichord Music."12

- A. Gould. "The Keyboard Variation Suite and Suite Variation in the Seventeenth and Eighteenth Centuries."13

- C. Miner. "A Comparative Study of English, French, and German Keyboard Suites of the Sixteenth, Seventeenth, and Eighteenth Centuries."14

- H. Schott. "A Critical Edition of the Works of J. J. Froberger.",15

- A. Somer. "The Keyboard Music of Johann Jakob Froberger.,"16

From among this selection, Miner's contribution proves to be the most helpful; she not only covers thoroughly the three most important countries from which the keyboard suite developed (England, France, and Germany), but also discusses the first three centuries of its development.

Articles from periodicals and journals typically provide a level of specialization that is not of much assistance in a project of this nature; but several did allow for some interesting, if highly specific, contributions:

- W. Apel. "Early German Keyboard Music."17

- T. Dart. "On Couperin's Harpsichord Music.",18

\footnotetext{
${ }^{12}$ Fuller, D. "Eighteenth-Century French Harpsichord Music." (PhD diss., Harvard, 1965).

${ }^{13}$ Gould, A. "The Keyboard Variation Suite and Suite Variation in the Seventeenth and Eighteenth Centuries." (MM thesis, Indiana University, 1951).

${ }^{14}$ Miner, C. "A Comparative Study of English, French, and German Keyboard Suites of the Sixteenth, Seventeenth, and Eighteenth Centuries." (MM thesis, University of South Dakota, 1968).

${ }^{15}$ Schott, H. "A Critical Edition of the Works of J. J. Froberger." (PhD diss., University of Oxford, 1977).

${ }^{16}$ Somer, A. "The Keyboard Music of Johann Jakob Froberger." (PhD diss., University of Michigan, 1962).

${ }^{17}$ Apel, W. "Early German Keyboard Music," Musical Quarterly, April (1937).
} 
- A. Dürr. "The Historical Background of the Composition of J. S. Bach's Clavier Suites."19

- J. Koster. "The Harpsichord Culture in Bach's Environs.",20

- M. Parker. "Some Speculations on the French Keyboard Suites of the Seventeenth and Early Eighteenth Centuries." 21

- G. Abraham. "Handel's Clavier Music."22

- G. Leonhardt. "Johann Jakob Froberger and His Music."23

- G. Hendrie. "Some Reflections on the Keyboard Music of Jean-Philippe Rameau (1683-1764).,"24

- D. Schulenberg. "Composition and Improvisation in the School of J. S. Bach."25

The articles by Dart, Dürr, and Abraham were the most helpful from among this selection since they deal with the compositions of three of the late Baroque Era's greatest writers of keyboard suites: François Couperin, Handel, and Bach.

Although several other areas of research were consulted, the most useful source of assistance in terms of locating information about the development of the keyboard suite was the Internet, especially the New Grove Online Dictionary of Music and Musicians.

Several articles from this source provided especially well-written and helpful information:

\footnotetext{
${ }^{18}$ Dart, T. “On Couperin's Harpsichord Music,” Musical Times 110 (1969).

${ }^{19}$ Dürr, A. "The Historical Background of the Composition of J. S. Bach's Clavier Suites," Bach 16, No. 1 (1985).

${ }^{20}$ Koster, J. "The Harpsichord Culture in Bach's Environs," Bach Perspectives IV: The Music of J. S. Bach: Analysis and Interpretation (1999), Ed. by David Schulenberg.

${ }^{21}$ Parker, M. "Some Speculations on the French Keyboard Suites of the Seventeenth and Early-Eighteenth Centuries," International Review of the Aesthetics and Sociology of Music Vol. 7, No. 2 (1976).

${ }^{22}$ Abraham, G. "Handel's Clavier Music," Music and Letters 16 (1935).

${ }^{23}$ Leonhart, G. "Johann Jakob Froberger and His Music," L'Organo 6 (1968).

${ }^{24}$ Hendrie, G. "Some Reflections on the Keyboard Music of Jean-Philippe Rameau (1683-1764)," Studies in Music [Australia] 22, (1988).

${ }^{25}$ Schulenberg, D. "Composition and Improvisation in the School of J. S. Bach," In Bach Perspectives I (1995), Ed. by Russell Stinson.
} 
- J. Caldwell. "Sources of Keyboard Music to 1660.,"26

- J. Caldwell. "Sources of Keyboard Music to c.1750."27

- D. Fuller. "Suite.,"28

- R. Hudson. "Sarabande.",29

- D. Ledbetter. "Prelude.",30

- M. Little. "Gigue."31

- M. Little and S. Cusick. "Allemande.,"32

- M. Little and S. Cusick. "Courante.",33

Despite the fact that the entire history of the suite for all solo instruments and

instrumental ensembles is covered by Fuller's article, it is by far the most useful source for information about the keyboard suite through the $18^{\text {th }}$ Century from among the resources mentioned above. Being equipped with knowledge about the history of the suite for lute, for example, provides one with valuable insight into how the keyboard suite (which came along many years after the lute suite) developed its own set of unique characteristics.

${ }^{26}$ Caldwell, J. "Sources of Keyboard Music to 1660," The New Grove Dictionary of Music and Musicians. Ed. By L. Macy. (Accessed 11/14/07) http://www.newgrovemusic.com.

${ }^{27}$ Caldwell, J. "Sources of Keyboard Music to c.1750," The New Grove Dictionary of Music and Musicians. Ed. by L. Macy. (Accessed 11/15/07) http://www.newgrovemusic.com.

${ }^{28}$ Fuller, D. "Suite," The New Grove Dictionary of Music and Musicians. Ed. by L. Macy. (Accessed 11/14/07) http://www.newgrovemusic.com.

${ }^{29}$ Hudson, R. "Sarabande," The New Grove Dictionary of Music and Musicians. Ed. by L. Macy. (Accessed 3/21/09) http://www.newgrovemusic.com.

${ }^{30}$ Ledbetter, D. "Prelude," The New Grove Dictionary of Music and Musicians. Ed. by L. Macy. (Accessed 3/21/09) http://www.newgrovemusic.com.

${ }^{31}$ Little, M. "Gigue," The New Grove Dictionary of Music and Musicians. Ed. by L. Macy. (Accessed 3/21/09) http://www.newgrovemusic.com.

${ }^{32}$ Little, M. and S. Cusick. "Allemande," The New Grove Dictionary of Music and Musicians. Ed. by L. Macy. (Accessed 3/21/09) http://www.newgrovemusic.com.

${ }^{33}$ Little, M. and S. Cusick. "Courante," The New Grove Dictionary of Music and Musicians. Ed. by L. Macy. (Accessed 3/22/09) http://www.newgrovemusic.com. 


\section{Chapter III}

\section{The Origins of the Keyboard Suite and its Primary Characteristics}

"Suite" (a French term meaning "together") first entered musical terminology in 1557 as a designation for a group of branles and continued with that meaning until such groups ceased to be danced. ${ }^{34}$ The branle (sometimes called bransle), a rustic rounddance of French origin, was at one time carried out to the singing of dancers. It enjoyed great popularity at the court of Louis XIV (1638-1715) but had earlier been taken up in England; William Shakespeare (1564-1616) called it a "Brawl.,"35 Contemporary reports describe the branle as a sideways step or movement in the 15th- and 16th-Century basse danse, a term which described a variety of French dances of popular character that were widely cultivated over several centuries. Some branles are still danced in France, and branle-like dances (line and circle dances) are popular in many cultures.

A group dance, the branle involves several couples arranged in a circle, in a single-file line, or in a line of couples. Randle Cotgrave (d. 1634?), an English lexicographer, vividly defined the branle in his Dictionarie of the French and English Tongues (London, 1611): Bransle:

... a totter, swing, or swindge; a shake, shog, or shocke; a stirring, an uncertain and inconstant motion; ... also, a brawl, or daunce, wherein many (men, and women) holding by the hands sometimes in a ring, and otherwise at length, move all together. ${ }^{36}$

\footnotetext{
${ }^{34}$ Fuller, D. "Suite," The New Grove Dictionary of Music and Musicians. Ed. by L. Macy. (Accessed 11/14/07) http://www.newgrovemusic.com.

${ }^{35}$ Kennedy, M. Ed. The Oxford Dictionary of Music. (New York: Oxford University Press, Inc., 2006), 117.

${ }^{36}$ Heartz, D. and P. Rader. "Branle," The New Grove Dictionary of Music and Musicians. Ed. by L. Macy. (Accessed 1/5/10) http://www.newgrovemusic.com.
} 
However, with the passage of time the branle fell out of favor, and several different stylized dances, such as allemandes, courantes, sarabandes, gigues, bourrées, etc., became integral parts of the suite as it gradually took on a definitive but highly flexible form. This process of development was an important step in the overall creation of instrumental suites prior to 1700 and beyond.

Another important developmental step for the suite genre was suggested by an Englishman, Thomas Mace (1612-1706), who was the first writer to describe the suite as a composite musical form with a conventional order of pieces; according to Mace it consisted of an improvised prelude followed by an allemande, ayre, courante, sarabande, and toy "or what you please," all linked by a common tonic and "some kind of Resemblance in Conceits, Natures, or Humours. ${ }^{, 37}$ Mace's use of a French-derived term is evidence that "suite" as a term for groupings of preludes, allemandes, courantes, and sarabandes had already been established among musicians in France, whence it probably came to England along with French tuning and musical styles.

Mace also used the term "sett" as a synonym for suite, and "sett" was so used in England from time to time into the $20^{\text {th }}$ Century. Roger North (1651-1734) also spoke of "setts of musick which were called fancys, ${ }^{, 38}$ in which a fantasia is followed by dance movements. However, "sett" more often meant a number of works of the same type; except for sets of variations, the word "sett" does not normally imply performance at a single sitting.

Other terms that have been used over the course of time in the sense of a suite include partita, overture, and ordre. The use of the French term "ouverture" as a

\footnotetext{
${ }^{37}$ Fuller.

${ }^{38}$ Fuller.
} 
designation for suites beginning with an overture was typical of German composers, who also had a great interest in collective titles that indicated the social attitudes and intentions behind their vast production of suites. Examples are to be found in Johann Christoph Pezel's (1639-1694) Delitiae Musicales, Esaias Reusner's (1636-1679) Musicalische Gesellschafts-Ergetzung, Andreas Werckmeister's (1645-1706) Musicalische Privatlust, Johann Adam Reincken's (1623-1722) Hortus Musicus, and Johann Caspar Ferdinand Fischer's (1670-1746) Musicalisches Blumen-Büschlein. A listing of each type of piece in the collection usually follows these titles; the division into suites, at least in collections before 1675 , can be deduced from an examination of the contents. ${ }^{39}$

The "classical" suite as mentioned in the Introduction is based on a fixed "core" of dances developed during the Baroque Era. It is here understood to consist of the following sequence: allemande, courante, and sarabande (hereafter identified as A-C-S), with or without a gigue (G). Duplication of these dances (especially courantes), the addition of doubles (variations), the incorporation of other pieces among the basic three or four dances, and the presence of introductory movements do not affect the "classical" status of a suite so long as the basic condition is met that the suite should be of reasonable length for playing in a single sitting. ${ }^{40}$ Definitions, characteristics, and the historical development of each of these dances will be addressed in Chapter IV.

In contrast to the classical suite, there is a considerable amount of speculation about the principles of ordering the dances based on fixed ideas regarding their characteristics, which in fact changed greatly during the course of the $17^{\text {th }}$ Century. For

\footnotetext{
${ }^{39}$ Fuller.

${ }^{40}$ Fuller.
} 
example, the sarabande is sometimes fast and sometimes slow, and it is oftentimes not possible to tell from appearances what the speed is supposed to be. ${ }^{41}$ The gigue, especially, took shape in a variety of guises, and one cannot be sure of the correct way of playing the many examples in $2 / 2,4 / 4$, or $6 / 8$ time. $^{42}$

Of greater importance is the fact that the majority of Baroque keyboard suites are simply too diverse to support any given single definition. Furthermore, for a large number of them, including those by very influential composers such as Froberger and Handel, the composition of the pieces and their arrangement in order were two separate acts, sometimes carried out by two different people (composer/publisher or composer/scribe). Often it cannot be known how a suite came to be in its current form. Finally, one cannot even be sure that many series of pieces (especially those by French composers) were meant to be played consecutively at a single sitting. In practice, French harpsichord pieces were more often than not played out of context, especially at home and in informal settings.

If the search for a consistent principle of the suite seems futile, nevertheless there may be one characteristic that always distinguishes suites from other multi-movement works: The quality of a unified collection seems never to be entirely absent. Unlike the sonata, a suite typically consists of individual pieces whose character and identity derives partly from outside sources. ${ }^{43}$ Oftentimes, the pieces are based on the pre-existing forms

\footnotetext{
${ }^{41}$ Hudson, R. "Sarabande," The New Grove Dictionary of Music and Musicians. Ed. by L. Macy. (Accessed 3/21/09) http://www.newgrovemusic.com.

${ }^{42}$ Little, M. "Gigue," The New Grove Dictionary of Music and Musicians. Ed. by L. Macy. (Accessed 3/21/09) http://www.newgrovemusic.com.

${ }^{43}$ Gould, A. "The Keyboard Variation Suite and Suite Variation in the Seventeenth and Eighteenth Centuries." (MM thesis, Indiana University, 1951).
} 
and styles of dances, but they may also have programmatic associations indicated by titles. François Couperin provided many prominent examples, of which this is one:

Example 3.1 François Couperin: "Rondeau." from Ordre No. 1, "Les Sylvains." Please note that Couperin employs the term ordre rather than suite. He used this term to describe all of his works in this genre. ${ }^{44}$

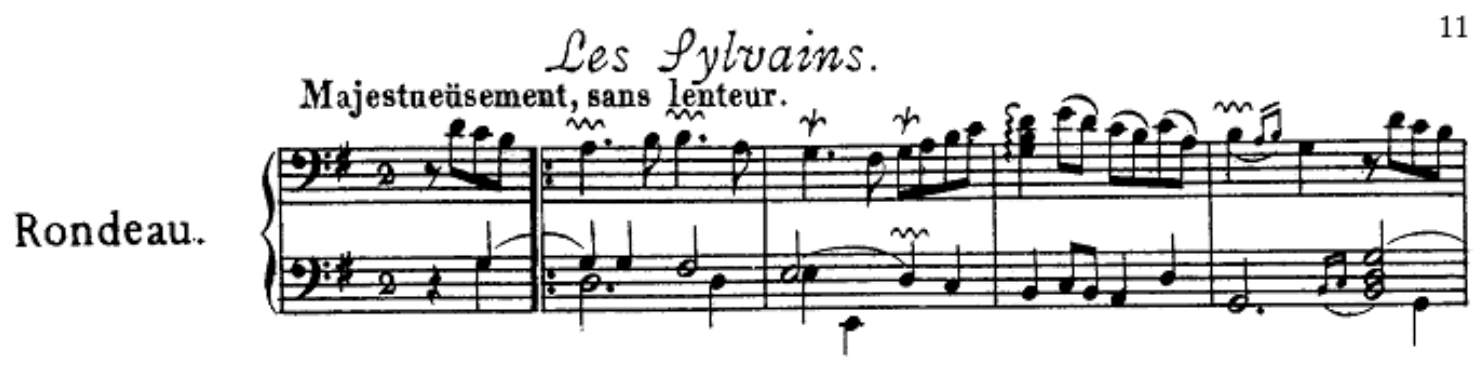

In the late Baroque period, when the interaction between sonata and suite was rather complex, tonality became a useful test of whether a piece should be called one or the other, and this was recognized as so by $18^{\text {th }}$-Century theoreticians. The principle that all the pieces of a suite are in the same key became a part of dictionary definitions up to the present (a principle that in reality was abandoned after 1800). In turn, a plausible but unfounded rationale for key unity was set forth; it was said that suites did not change key because of the difficulty of retuning one's lute between the performance of various dances within one suite or "sett" of pieces. While it is true that the first solo instrumental suites were typically performed on the lute and that the lute has limited capabilities when it comes to modulating from one key to another, these facts do not provide definitive proof as to why the suite was typically written with every movement in the same key.

\footnotetext{
${ }^{44}$ IMSLP [International Music Score Library Project]/ Petrucci Music Library. (Accessed 4/3/09) http://imslp.org/wiki/Main_Page.
} 
This is especially so upon considering that suite movements were often performed out of order. ${ }^{45}$

We might also speculate that key unity determined the tonal plan of suites for all instrumental media, but not of sonatas. Given the nature of the suite as an amalgam of pieces, it was only natural that one of the oldest classification systems in Western art music should govern the grouping, that of mode or key.

Until tonality was recognized as a structural resource, it probably would not have occurred to musicians to juxtapose entire pieces in different keys for tonal contrast. The tonal variety in sonatas was the result of that genre's ancestry in multi-sectional pieces such as the Italian canzona, in which cadences in various keys succeeded one another. In contrast, when composers began to recognize the suite as a genre in its own right, the tradition of tonal unity was already strong enough to have acquired the momentum to carry it well into the $18^{\text {th }}$ Century. However, this tradition did not prevent composers from contrasting the major and minor modes, a practice that was especially common in paired alternating dances from the last quarter of the $17^{\text {th }}$ Century.

In light of this strong tradition, the unification of the suite by other than tonal means has been a concern of composers throughout its history. The true variation suite is the most obvious manifestation of this concern, but much more common is a linking of two or three pieces by thematic similarities that are sometimes obvious but perhaps more often vague enough to make it difficult to decide whether they are intentional, the result of chance, or the workings of the subconscious mind. ${ }^{46}$

\footnotetext{
${ }^{45}$ Fuller.

${ }^{46}$ Gould.
} 
In essence, Baroque keyboard suites defy any single definition but do employ a number of common characteristics that may be viewed as relatively consistent. My research has led me to the following list of keyboard-suite principles:

1. No fewer than three movements (oftentimes many more).

2. Barring preludes, overtures, etc., suites are composed of dance forms.

3. With few exceptions, key unity is maintained throughout the movements.

4. Similar motivic and rhythmic characteristics oftentimes permeate all movements (variation suites). 


\section{Chapter IV}

\section{The Keyboard Dances}

In Chapter III, I repeatedly made references to movements such as "allemande," "courante," "sarabande," and "gigue." Now I need to clarify the typical characteristics of these dances as well as bring to light the numerous other dance movements that were used by composers throughout the history of the Baroque keyboard suite. Many of these definitions include references to composers who excelled at the composition of these dances and incorporate a discussion of the keyboard works of Bach, who has historically emerged as the greatest master of the keyboard suite.

While it shall not be possible to address at length every dance form that may be found in keyboard suites, I shall list many of the dances in alphabetical order and proceed to define those that are used most frequently. The variety of dances and other movements that may be found is nothing short of astonishing and is a testament to the highly flexible approach taken by many keyboard composers towards the suite genre. In the list that follows, please note that the spellings of these movements could vary somewhat from region to region:

1. Air

2. Air and Variations

3. Allemande

4. Anglaise

5. Bagatelle

6. Ballet

7. Barcarole

8. Bassadanza

9. Bourrée

10. Boutade

11. Brusque 
12. Burlesca

13. Canary

14. Canción

15. Capriccio

16. Cantabile

17. Chaconne

18. Cibel

19. Courante

20. Double

21. Echo

22. Entrée

23. Fanfarinette

24. Fantasie

25. Forlane

26. Fugue

27. Galliard

28. Gavotte

29. Gigue

30. Ground

31. Horne Pipe

32. Leyenda

33. Loure

34. Marche

35. Minuet

36. Musette

37. Overture

38. Passacaglia

39. Passaggio

40. Passepied

41. Pastorelle

42. Pavane

43. Polonaise

44. Prelude

45. Rant

46. Rigaudon

47. Rittournelle

48. Rondeau

49. Saltarello

50. Sarabande

51. Savoyard

52. Scherzo

53. Seguidilla

54. Serenata

55. Sinfonia

56. Sonata

57. Sevillana 
58. Tambourin

59. Toccata

60. Tombeau

61. Trio

62. Vénitienne

63. Virago

64. Volte

In Chapter I, I made reference to the "classical" suite, and in Chapter III, I discussed some of its basic characteristics. Because the allemande, courante, and sarabande, frequently followed by a gigue, eventually came to be the standard core of the suite, I first need to define and provide historical information about these dances, following with shorter definitions of many of the other more common dances and movements as well:

\section{-Allemande-}

The allemande was one of the most popular of the Baroque instrumental dances and became a standard movement of the suite, along with the courante, sarabande, and gigue. The word itself comes from the French word for "Germany," which is "Allemagne." The origins of the allemande are at best obscure; possibly the dance began as a French or German variant of the basse danse. The earliest known literary use of the title "allemande" occurs in a short dancing manual devoted to the basse danse published in London in 1521 (Here followeth the Manner of Dancing Bace dances after the Use of France and Other Places translated out of French in English by Robert Coplande). ${ }^{47}$

In the middle of the $16^{\text {th }}$ Century, allemandes for lute, guitar, cittern, keyboard, and instrumental ensemble began to appear both in prints and also in manuscripts across

${ }^{47}$ Little, M. and S. Cusick. "Allemande," The New Grove Dictionary of Music and Musicians. Ed. by L. Macy. (Accessed 3/21/09) http://www.newgrovemusic.com. 
Europe. French and Netherlandish printers seem to have been responsible for the application of the word "allemande" to the new dance. Many of these early allemandes were grouped together at the end of dance music collections after the basse danses, pavanes, and galliards, and many were followed by afterdances (with such titles as "nachtanz," "reprise," and "recoupe") using the same harmonic and melodic material for a faster triple-meter dance.

Only one French dance choreography source with music for the allemande is extant from this period, that given by Thoinot Arbeau (1520-1595) (a highly regarded expert on courtly dancing) in Orchésographie (1588). It is described as a couple dance, with the man and woman side by side; the dancers proceed in a line of couples from one end of a hall to the other, each turning his partner around in such a way as to reverse the line and go back to the original place. Arbeau referred to it as "a plain dance of a certain gravity," and claimed that it must be among "our most ancient dances, for we descended from the Germans. ${ }^{, 48}$ Furthermore, contemporary literary references to the allemande consistently mention "almain leaps" (as in Ben Jonson's (1572/3-1637) The Devil is an Ass (Act I scene i): “And take his almain-leap into a custard"). ${ }^{49}$

As the instrumental allemande took on definitive traits and characteristics in the $16^{\text {th }}$ Century, it developed into a dance that is written in duple meter with no syncopation; that consists of two repeated strains, each of which is in turn made of repeated motives; and that has a homophonic texture. As in many $16^{\text {th }}$ - and early $17^{\text {th }}$-Century allemandes, the tonality at the beginning of the second strain of the dance contrasts with that of the first, and this contrast is often emphasized by the use of shorter phrases. The conclusion

\footnotetext{
${ }^{48}$ Fuller, D. "Suite," The New Grove Dictionary of Music and Musicians. Ed. by L. Macy. (Accessed 11/14/07) http://www.newgrovemusic.com.

${ }^{49}$ Little and Cusick, "Allemande."
} 
of the second strain returns to a variation of the opening motive, creating a rounded $\mathrm{ABA}^{\prime}$ form. $^{50}$

Often the middle section of an allemande stresses the area of a half-cadence (i.e., the modern dominant), although emphasis on the subdominant and minor supertonic, as well as on the relative major, is also common. Such a formal scheme seems to be one of the chief characteristics of the allemande, for it occurs even in dances of only two strains (the first phrase of the second strain would either hover around a cadence formula in the contrasting "key" or begin with a cadence in that "key" and move by sequence back to the original tonal area). ${ }^{51}$

As far as keyboard allemandes are concerned, French Baroque composers such as Jean-Henri d'Anglebert (1629-1691), Jacques Champion de Chambonnières (1601-1672), and Louis (1626-1661) and François Couperin all incorporated allemandes into their keyboard suites (or ordres) that were usually published in volumes entitled Pièces de Clavecin.

${ }^{50}$ Silbiger, A. Ed. Keyboard Music Before 1700. (New York: Routledge, 2004), 128.

${ }^{51}$ Little and Cusick, "Allemande." 
Example 4.1 Chambonnières: "Allemande" from Pièces de Clavecin. Vol. II (1670). ${ }^{52}$
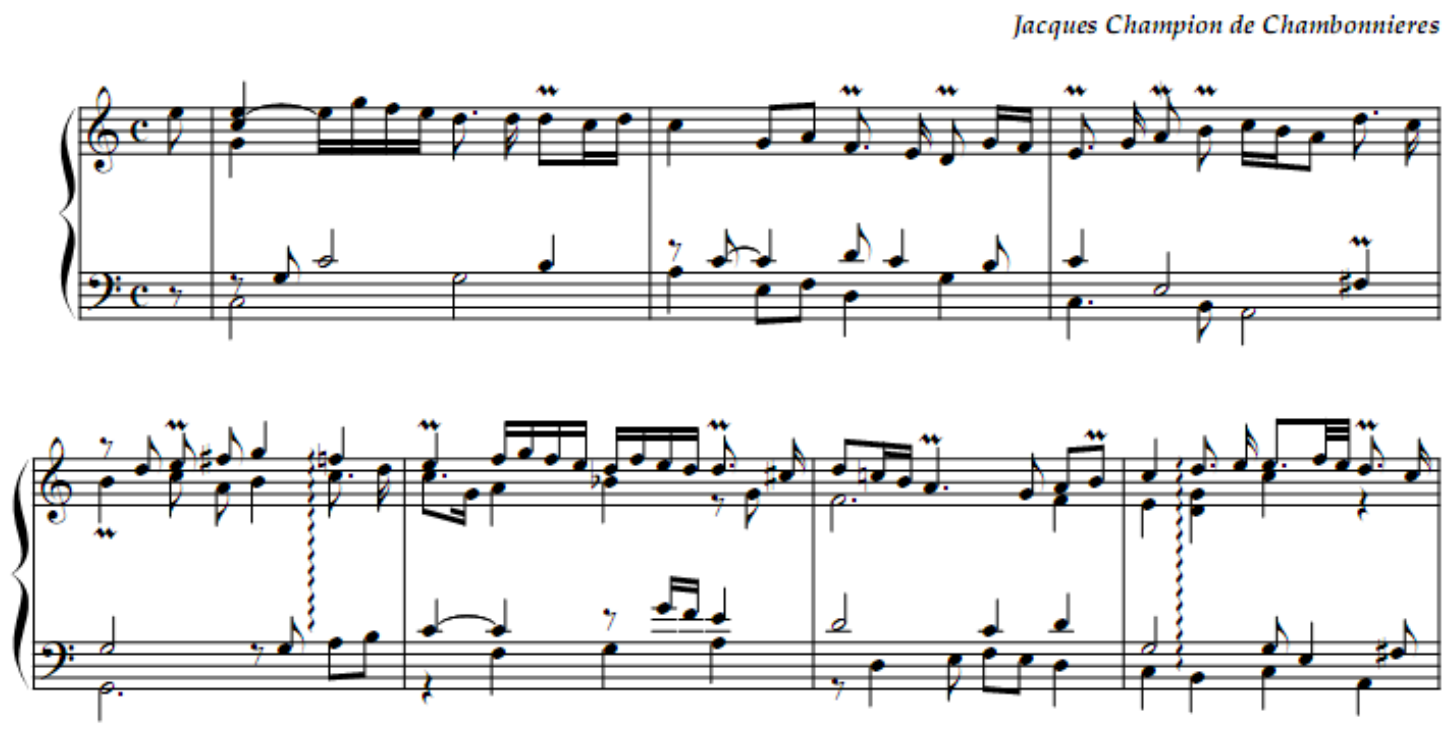

Two of the greatest German masters of the keyboard suite were Froberger and Bach. While Froberger brought the keyboard allemande to its apex in the $17^{\text {th }}$-Century, Bach clearly followed the example of Froberger and brought the keyboard allemande to its greatest manifestation in the late Baroque. Bach employed a wide variety of styles in his keyboard allemandes, including French-overture style in Partitas No. 3 in A minor and No. 6 in E minor (BWV 827 and 830), ornamented aria in Partitas No. 4 in D major and No. 5 in G major (BWV 828 and 829), and two-voice counterpoint using triplets in Partita No. $5 .^{53}$

\footnotetext{
${ }^{52}$ IMSLP [International Music Score Library Project]/ Petrucci Music Library. (Accessed 4/3/09) http://imslp.org/wiki/Main_Page.

${ }^{53}$ Little and Cusick, "Allemande."
} 
For comparison, Example 4.2 shows the openings of allemandes by Froberger and Bach; the dotted rhythms are employed in a similar fashion in each allemande, but Bach incorporates a much higher level of keyboard virtuosity in his composition.

Example 4.2 Allemandes by Froberger: Suite No. 7 in E minor and Bach: Partita No. $6 .{ }^{54}$

\section{Suite VII in E minor}

(first suite from second book of music edited in 1656)

Johann JAKob Froberger (1616 - 1667)

ALLEMANDE
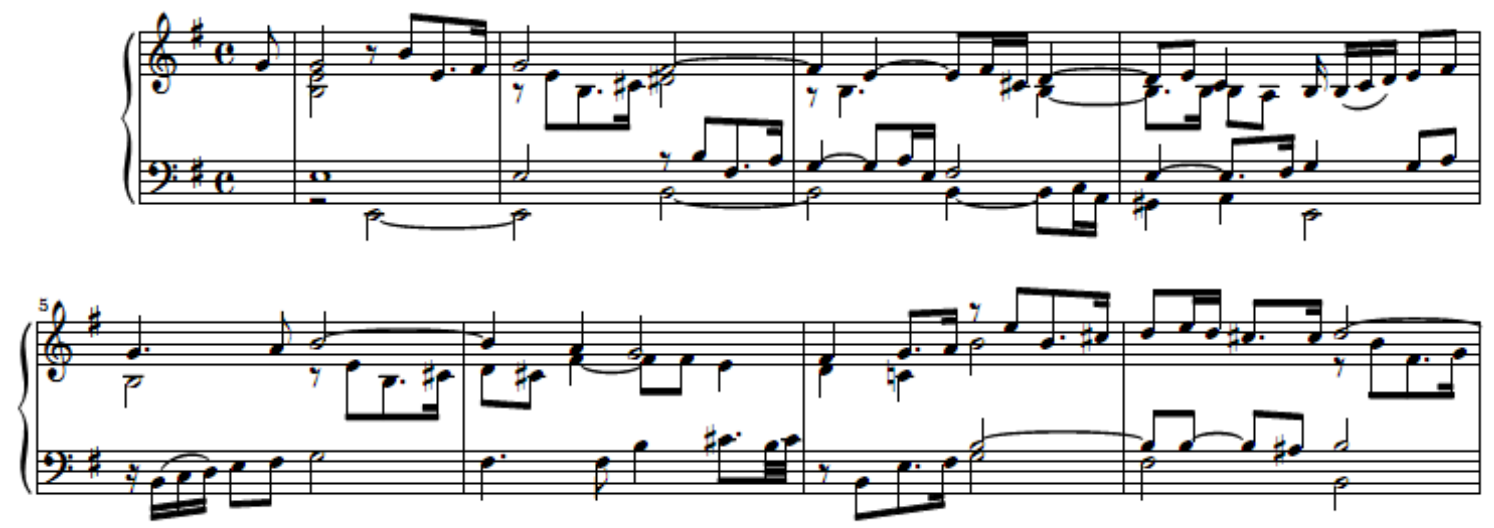

${ }^{54}$ IMSLP. 
Bach: "Allemande"
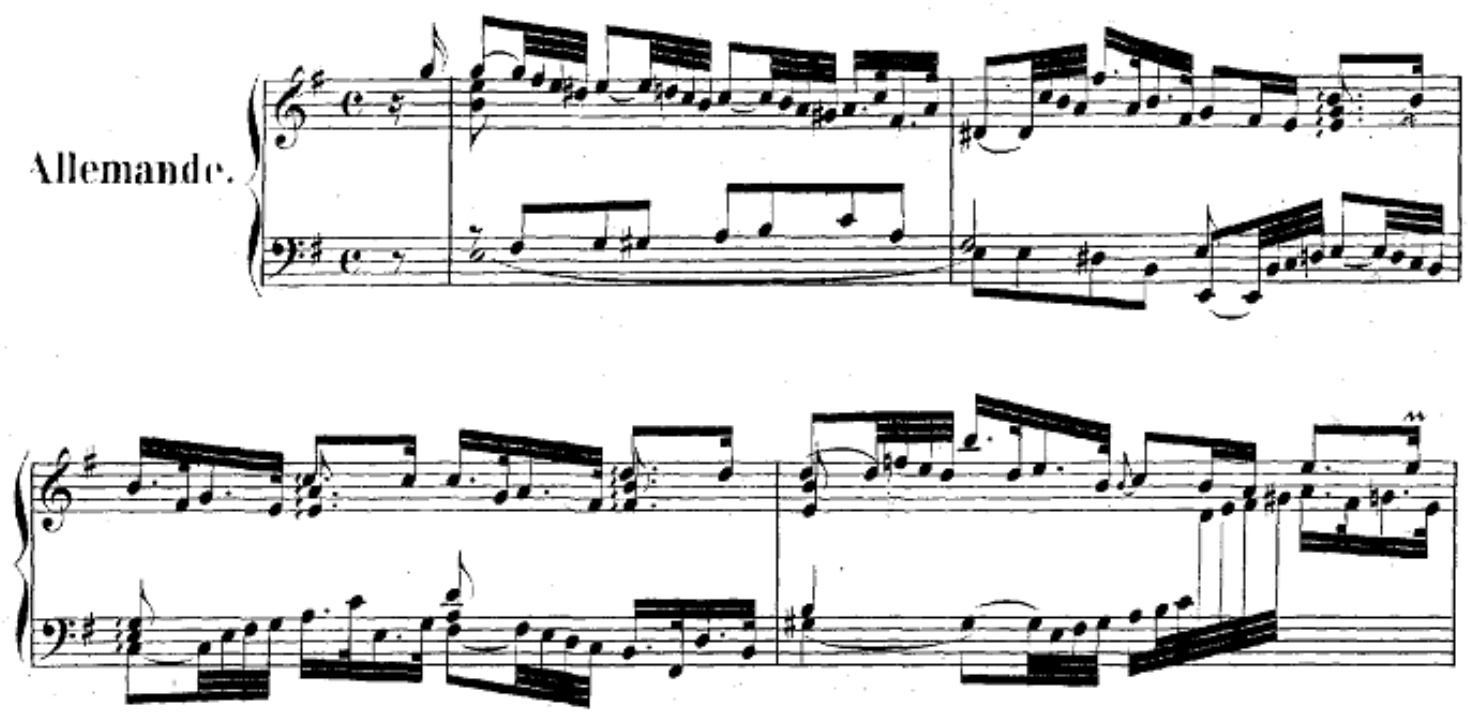

-Courante-

The origins of the courante are also rather obscure, as only a few examples from the $16^{\text {th }}$ Century exist. The word itself comes from a root meaning "flowing" or “running." During the early $17^{\text {th }}$ Century, it was a popular dance in both France and Italy. By the end of the century there were two distinct types of courante: the Italian "corrente" and the French courante. The corrente is a fast triple-meter dance in 3/4 or 3/8, typically in binary form with a relatively homophonic texture, balanced phrases, virtuoso performance style and a clear harmonic and rhythmic structure.

The courante is a "majestic" and "grave" triple meter dance, oftentimes in $3 / 2$, characterized by rhythmic ambiguity, frequent use of modal harmonies and melodies, and a contrapuntal texture. Examples of both styles can be found together in early musical sources that include the dance where the given names seem not to have implied stylistic 
distinctions, as both styles are labeled "corrente" in Italian sources and "courante" in German sources. ${ }^{55}$

Example 4.3 Louis-Claude Daquin (1692-1772) "Courante" from Deuxiême Suite (1735). This is an example of the courante as cultivated by the French. ${ }^{56}$

\section{Courante}
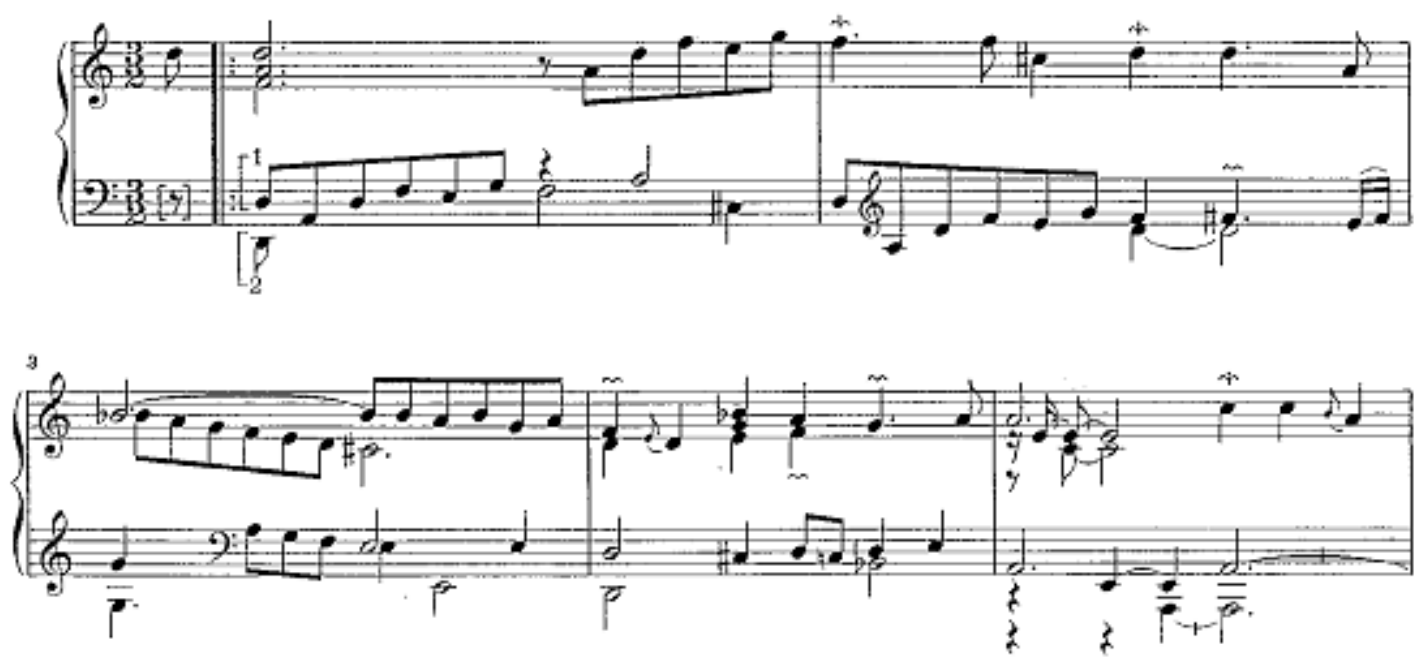

It is not certain whether the two styles had a common ancestor. National taste and idiomatic instrumental styles may have predisposed the French, for example, to stress the contrapuntal and metrical interest possible in one kind of courante, just as the French taste for elegant choreography may have altered the courtship dance of the early $17^{\text {th }}$ Century into the sophisticated, serious court dance called "courante. ${ }^{.57}$ French taste subsequently passed to many German composers, especially those who had strong ties with the French court, such as Froberger and Fischer, while Georg Muffat (1653-1704)

\footnotetext{
${ }^{55}$ Little, M. and S. Cusick. "Courante," The New Grove Dictionary of Music and Musicians. Ed. by L. Macy. (Accessed 3/22/09) http://www.newgrovemusic.com.

${ }^{56}$ IMSLP.

${ }^{57}$ Little and Cusick, "Courante."
} 
and Handel, trained in Italy, preferred the simpler and livelier Italian corrente style. ${ }^{58}$ More specifically, Handel placed correntes (although he called them "courantes") after the opening allemandes in his keyboard suites; all are in 3/4, and all share a simple texture, a tendency to rapid movement in the upper part, and the binary form of correntes by contemporary Italians. ${ }^{59}$

The $17^{\text {th }}$-Century Italian corrente was a courtship dance combining fixed with improvised step patterns. A general air of cheerfulness prevailed, the dancers seeming to run rather than walk, moving from side to side rather than proceeding backwards and forwards. The steps used in the corrente mostly consisted of hop-step combinations (e.g. for a step onto the left foot one should hop on the right foot and then step forward on the left). ${ }^{60}$

Many of Bach's “courante" movements are actually correntes as well: in the first engraving of the keyboard Partitas (Clavier-Übung, I) (BWV 825-830), movements are clearly labeled either "corrente" or "courante"; editors have often omitted this distinction. Partitas No. 1 in B-flat major (BWV 825), No. 3, No. 5, and No. 6 all include correntes by Bach's ascription, as do the following French Suites: No. 2 in C minor (BWV 813), No. 4 in E-flat major (BWV 815), No. 5 in G major (BWV 816), and No. 6 in E major (BWV 817). These correntes are written either in $3 / 4$ or $3 / 8$ with a simple texture, clear harmonic and rhythmic movement, and triadic passagework in the upper part. ${ }^{61}$

\footnotetext{
${ }^{58}$ Silbiger, 129.

59 Abraham, G. “Handel's Clavier Music,” Music and Letters 16 (1935).

${ }^{60}$ Little and Cusick, "Courante."

${ }^{61}$ Little and Cusick, "Courante."
} 
Example 4.4 Bach: "Courante" from Partita No. 5. Here is an example of a Bach corrente that is erroneously labeled "Courante." 62
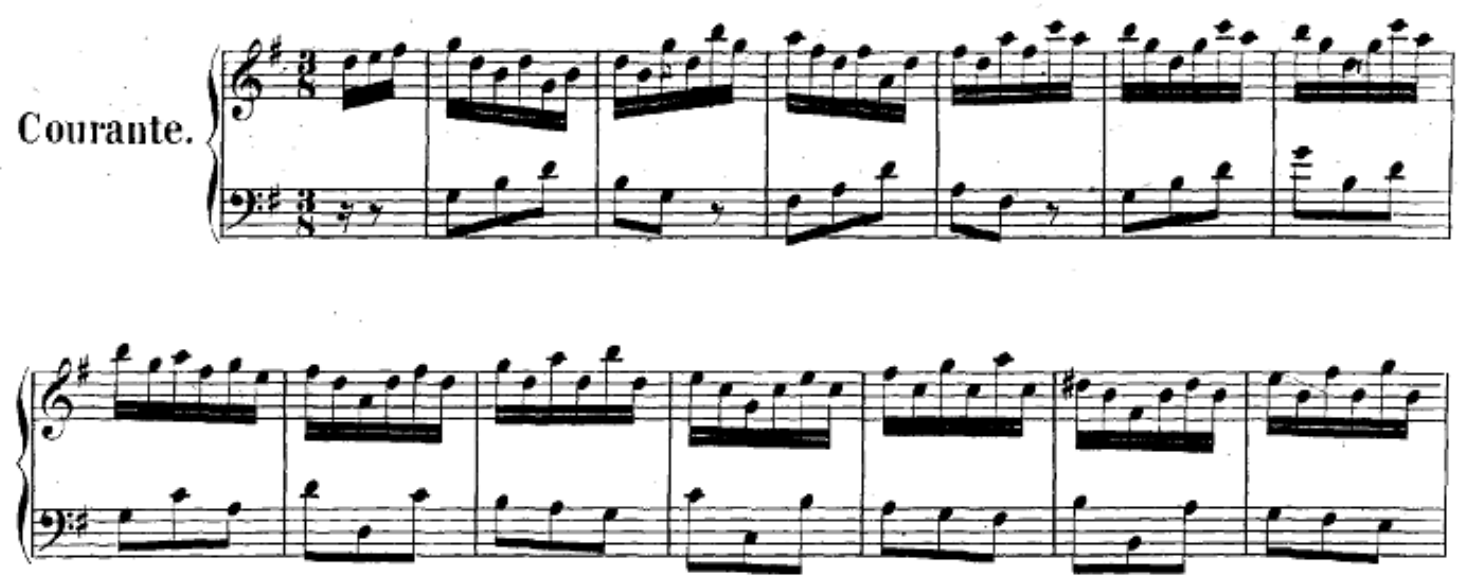

-Sarabande-

The sarabande (zarabanda) was one of the most popular Baroque instrumental dances and a standard movement of the suite, along with the allemande, courante, and gigue. It originated during the $16^{\text {th }}$ Century as a dance in Latin America that was later transported to Spain.

The sarabande was banned by Philip II of Spain (1527-1598) in 1583 because it

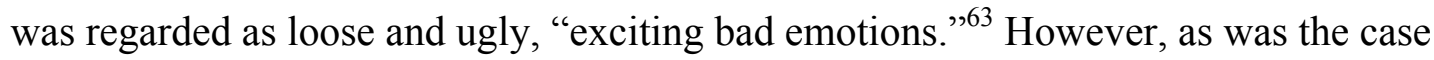
with the allemande in England, the danced sarabande continued to be mentioned in literature in the works of such authors as Miguel de Cervantes (1547-1616) and Lope de Vega (1562-1635). When originally performed, the dance was accompanied by the guitar, castanets and possibly other percussion instruments, and by a text with refrain. ${ }^{64}$

\footnotetext{
${ }^{62}$ IMSLP.

${ }^{63}$ Kennedy, M. Ed. The Oxford Dictionary of Music. (New York: Oxford University Press, Inc., 2006), 769.

${ }^{64}$ Hudson, R. "Sarabande," The New Grove Dictionary of Music and Musicians. Ed. by L. Macy. (Accessed 3/21/09) http://www.newgrovemusic.com
} 
Numerous examples of keyboard sarabandes began to appear around the mid- $17^{\text {th }}$ Century, especially in English keyboard music and often as the concluding movement in a suite; they include works by Matthew Locke (1622-1677), John Blow (1649-1708), and Purcell among others. By this time, a noticeable preference emerged among composers for an increasingly slow and deliberate kind of sarabande, in which the idiomatic and contrapuntal possibilities of the keyboard might be exploited. ${ }^{65}$

Example 4.5 Purcell: "Sarabande" from Suite in G major (Z. 661). Please note that this is a heavily edited edition of Purcell's keyboard works and that the score employs editorial crescendo and decrescendo indications along with a metronome marking; these could not have been Purcell's own indications. ${ }^{66}$
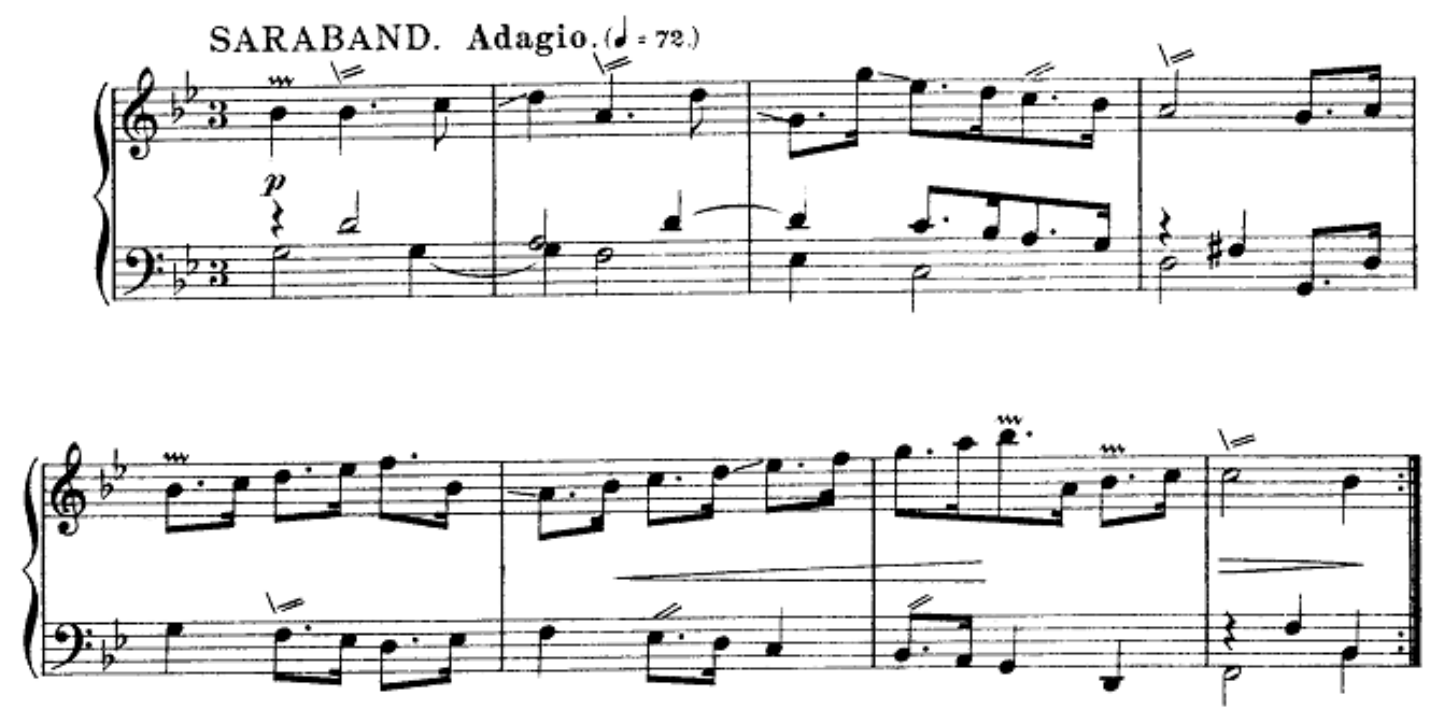

Many French and German sarabandes of the mid- and late Baroque appear as one of the dances in suites for keyboard. They usually are characterized by an intense and serious nature, though a few are tender and gracious, and are set in slow triple meter with

\footnotetext{
${ }^{65}$ Hudson.

${ }^{66}$ IMSLP.
} 
a strong sense of balance based on four-bar phrases. A binary form is most common, though variations and rondeau form may also be found, often with ornamented reprises or doubles. Frequently a reprise occurs at the end, an exact or slightly varied repetition of the final four bars of the piece.

Bach incorporates sarabandes in all of his keyboard Partitas, the Suite in E-flat major (BWV 819), the Suites in A minor (BWV 818 and 818a), the Suite in F minor (BWV 823), the Suite in A major (BWV 832), the Suite in B-flat major (BWV 821), all the English Suites (BWV 806-811), all the French Suites (BWV 812-817), and the Overture in the French Style in B minor (BWV 831). They display a variety of techniques and styles: variations or written-out doubles such as those found in English Suites No. 3 in G minor and No. 6 in D minor (BWV 808 and 811); elaborate, dramatic flourishes such as those in English Suite No. 1 in A major (BWV 806) and Partita No. 4; and entrée grave style found in Partita No. $5 .^{67}$

Example 4.6 Bach: "Sarabande" from Partita No. $5 .{ }^{68}$

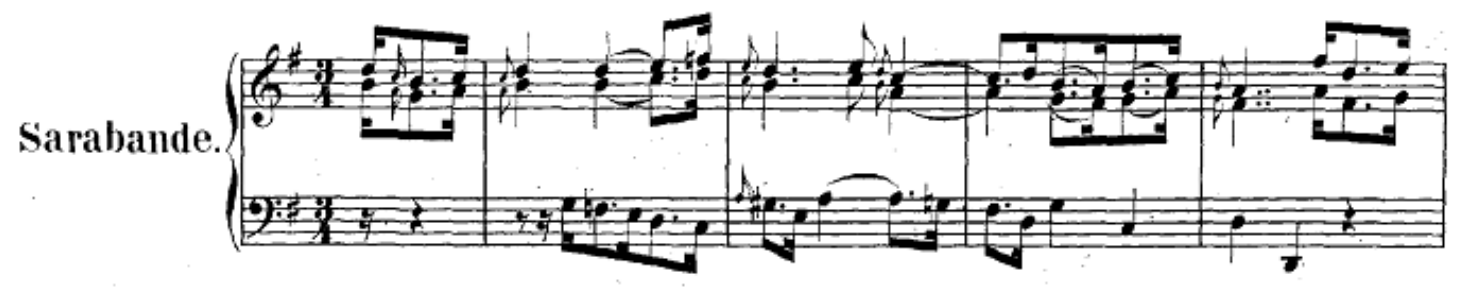

\footnotetext{
${ }^{67}$ Hudson.

${ }^{68}$ IMSLP.
} 
-Gigue-

The gigue, like the sarabande, was one of the most popular Baroque instrumental dances and became a standard movement of the suite, along with the allemande, courante, and sarabande. It apparently originated in the British Isles, where dances and tunes called "jig" have been known since the $15^{\text {th }}$ Century.

Although many $17^{\text {th }}$-Century gigues were notated in simple duple meter, most are in some kind of compound meter (i.e., with a triple subdivision of the duple beats), and most are in binary form. During the $17^{\text {th }}$ Century distinct French and Italian styles emerged (as was the case with other dances, i.e., courante vs. corrente). The French gigue was written in a moderate or fast tempo with irregular phrase lengths and an imitative, contrapuntal texture in which the opening motif of the second section was often an inversion of the first section's opening:

Example 4.7 Fischer: Opening measures of the "Gigue" from Calliope Suite in Musicalischer Parnassus followed by the opening measures of the second section from the same gigue. Notice the use of inversion between the first and second sections. ${ }^{69}$
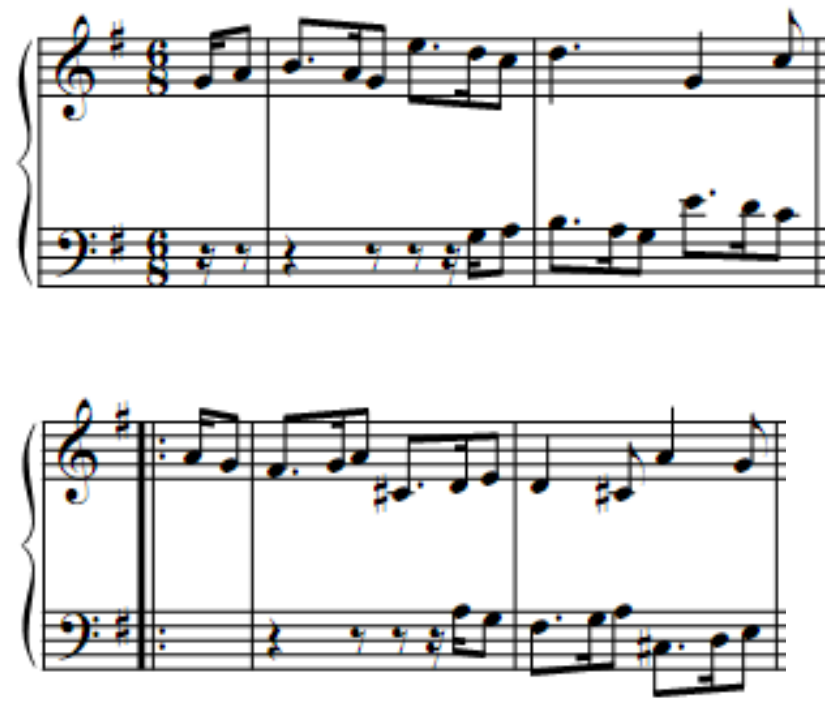

${ }^{69}$ IMSLP. 
The Italian giga moved much faster than the French gigue but had a slower harmonic rhythm; it was usually in 12/8 and originally marked "presto," with balanced four-bar phrases and a homophonic texture. From about 1690 both gigues and gigas appeared that were complex virtuoso solo pieces which used a wide variety of compositional techniques.

The various words for the dance form known as the jig or gigue have rather confused histories that have led to misinterpretations about the origins of the musical form. In French, Italian, and German, the word appears to be derived from "giga," a medieval word for fiddle (as in Dante Alighieri's (1265-1321) Paradiso, xiv. 110: 'E come giga ed arpa in tempraqtesa, De molte corde, fan dolce tintinno' [And as the viol and harp, their many strings, tuned into harmony, will ring out sweetly...]; this word is also used to refer to the musician who played such a fiddle.

The usage survives in modern German as Geige (violin), a continuation that has contributed most to past uncertainty about the gigue's origin. It is also believed that if the English word came from the European Continent, it came not from gigue or fiddle but from the verb "giguer," which means "to frolic, leap, or gambol."

Although no choreographies have survived for the $16^{\text {th }}$ Century jig, contemporary literary references suggest that jigs were fast pieces for one or more dance soloists with lively rhythms created by virtuoso footwork, and that they were somewhat bawdy (Shakespeare, Much Ado about Nothing, Act II scene i: "Wooing is hot and hasty like a Scottish jigge." $)^{70}$

\footnotetext{
${ }^{70}$ Little, M. "Gigue," The New Grove Dictionary of Music and Musicians. Ed. by L. Macy. (Accessed 3/21/09) http://www.newgrovemusic.com.
} 
Additionally, sung and danced jigs were a prominent feature of the stage entertainment called jigg, an improvised burlesque comedy for two to five actors, developed in Elizabethan England and enthusiastically adopted in Scandinavia and northern Germany. Little is known about either the music or the dances used in staged jiggs; verses were sung to popular tunes, some of which remained well known in instrumental versions (e.g., Walsingham, Goe from my window, Watkins Ale, Spanish Pavan). It is possible that the style of the original dance accompaniments is reflected in these pieces and in the jigs that appeared in English art music at the turn of the $17^{\text {th }}$ Century.

Jigs began to appear in English collections of lute music early in the $17^{\text {th }}$ Century, as independent pieces in binary form, as themes for variation sets, and occasionally as movements in longer works. These jigs are all written in four-bar phrases with a homophonic texture, some of them in simple duple meter and some in compound duple. ${ }^{71}$

The French lutenist, Jacques Gautier (fl. 1625-40), who for many years worked as court lutenist in London, is credited with having introduced some form of the jig into France upon his return there. Pieces called "gigue" soon began to appear in French harpsichord collections. Like their English counterparts, these gigues could be written in either simple or compound meter; but other elements of the original style, particularly the clarity of phrase and texture, began to change under the influence of the distinctive French style brisé, a term used to characterize the transference to the harpsichord of lute figuration. $^{72}$

\footnotetext{
${ }^{71}$ Little, "Gigue."

${ }^{72}$ Fuller.
} 
This newly stylized French gigue was first included regularly in suites by NicolasAntoine Lebègue (1631-1702), although it appeared in its soon-to-be-traditional place as the last movement in the suites of relatively few composers at the time. Example 4.8 shows the typically complex opening of a gigue by d'Anglebert:

Example 4.8 d'Anglebert: "Gigue" from Pièces de Clavecin, (1689). ${ }^{73}$

30

\section{Gigue}
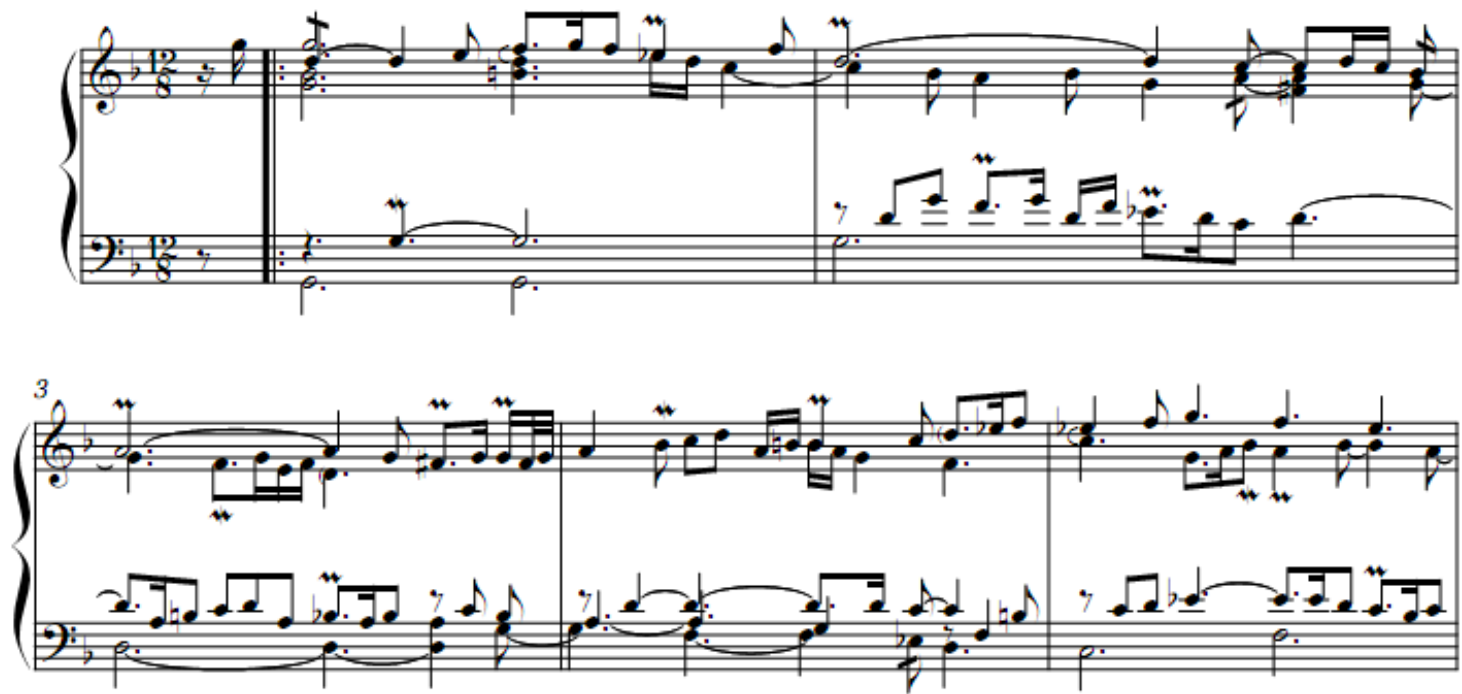

The earliest appearance of the term "gigue" in Germany was as the title of a variation in Wolfgang Ebner's (1612-1665) Aria 36 modis variata ... (1648), but the real popularity of the form seems to date from its introduction by Froberger as a standard movement in his keyboard suites. Froberger visited Paris in 1652, where he was influenced by Denis Gautier (1597-1672) (no relation to Jacques Gautier mentioned

${ }^{73}$ IMSLP. 
above) and Chambonnières; his gigues show fugato, style brisé, and the delicate nuances characteristic of French lutenists.

After Froberger, south German composers such as Johann Pachelbel (1653-1706) tended to compose rather simple gigues, relinquishing the fugato techniques brought from France, while composers in central and northern Germany such as Fischer, Reincken, Dieterich Buxtehude (1637-1707), Johann Kuhnau (1660-1722), Johann Mattheson (1681-1764), and Georg Böhm (1661-1733) preferred imitative gigues modeled on those of French harpsichordists, often unifying them by using an inversion of the opening motive as the main idea of the second strain. ${ }^{74}$

The Italian giga is an instrumental air derived from the English jig. Unlike the French gigue with its many unbalanced phrases, the beats in the giga are arranged in balanced groups of four or eight. Harmonic and melodic sequences appear frequently, and the texture tends to be less complicated than in the French form. The giga was adopted by French composers, notably Jean-Marie Leclair (1697-1764) and Jean-Joseph Cassanéa de Mondonville (1711-1772), and by such Germans as Reincken, Georg Philipp Telemann (1681-1767), Handel, and Bach.

French composers of the first half of the $18^{\text {th }}$ Century also included the gigue, particularly in keyboard and small-ensemble suites. Many works by François Couperin and Rameau, for example, include gigues written in the tradition of d'Anglebert and Lebègue; however, some also show influences from the Italian giga style, the contredanse, or the emerging Rococo style. In fact it is nearly impossible to classify the

\footnotetext{
${ }^{74}$ Little, "Gigue."
} 
gigue as a particular dance type after 1700 because it absorbed so many variants; the title "gigue" can mean a French gigue, an Italian giga, or some combination of the two. ${ }^{75}$

Some of the longest, most complex, and most contrapuntal gigues may be seen in the works of Bach, appearing under such diverse titles as "gigue," "giga," "jig," and "gique." Some are clearly in the French style, such as those of the French Suite No. 2 and the Overture in the French Style, as Example 4.9 reveals:

Example 4.9 Bach: "Gique" from the Overture in the French Style. ${ }^{76}$
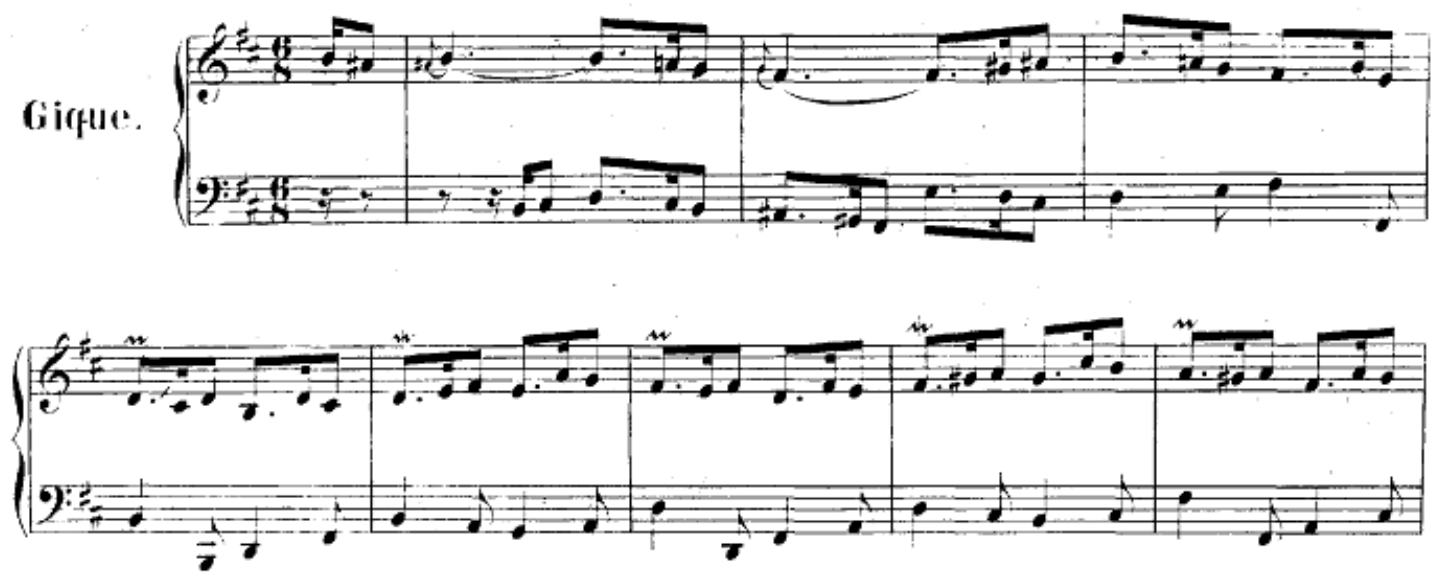

Bach's gigues in the Italian style fall into two metric categories: one has ternary groupings on the lowest level of rhythm, such as those of the English Suites No. 1, No. 3, No. 4 in F major (BWV 809), No. 5 in E minor (BWV 810), and No. 6, the French Suite No. 5, and the keyboard Partitas Nos. 1, 3, 4, and 6. A second kind has a duple level of rhythm below the ternary groupings, often with harmonic changes within the ternary

\footnotetext{
${ }^{75}$ Little, "Gigue."

${ }^{76}$ IMSLP.
} 
figure and few internal cadences, as in the French Suites No. 1 in D minor (BWV 812), No. 3 in B minor (BWV 814), No. 4, and No. $6 .{ }^{77}$

Example 4.10 Bach: "Gique" from English Suite No. 5. ${ }^{78}$
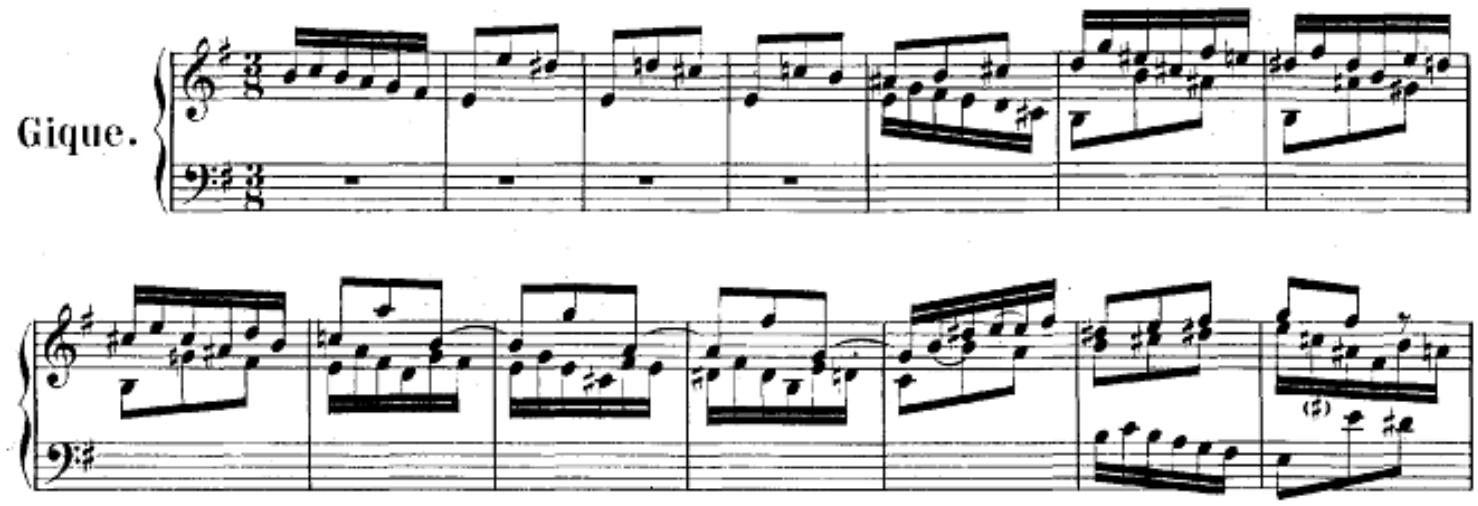

Following this discussion of the core dances of the classical suite, I shall define the more popular dances and movements also employed in keyboard suites. These movements, with the exception of the prelude, were oftentimes inserted between or after the core dances but were not essential to the classical suite structure. As is obvious from the list included at the beginning of this chapter, there are far too many optional dance movements to define all of them thoroughly; however, the stylized dances most often used by composers are mentioned in abbreviated definitions below.

-Prelude-

The term "prelude" (German Vorspiel), in its original usage, indicated a piece that preceded other music whose mode or key it was designed to introduce; was instrumental

\footnotetext{
${ }^{77}$ Miner, C. "A Comparative Study of English, French, and German Keyboard Suites of the Sixteenth, Seventeenth, and Eighteenth Centuries." (MM thesis, University of South Dakota, 1968).

${ }^{78}$ IMSLP.
} 
(the roots ludus and Spiel mean "played" as opposed to "sung"); and was improvised (hence the French préluder and the German präludieren, meaning "to improvise"). The term "praeambulum" (preamble) adds the rhetorical function of garnering the attention of an audience and introducing a topic. ${ }^{79}$

Simply stated, the prelude is a piece of music in free style that precedes something else, e.g., preceding a fugue or forming the first movement of a suite. ${ }^{80}$ The French were among the first to explore the possibilities of the prelude, particularly the unmeasured prelude. $17^{\text {th }}$-Century French clavecinistes held a special fascination for the unmeasured prelude, largely because its notation and performance style were so different from any other keyboard music. The genre was first cultivated by lutenists who, like the harpsichordists of the day, employed a short series of elaborate chordal and scalar passages - sometimes nothing more than three or four arpeggios - to accustom the fingers to the instrument and the ear to the tonality. The unmeasured prelude also offered an opportunity for free improvisation. ${ }^{81}$

\footnotetext{
${ }^{79}$ Ledbetter, D. "Prelude," The New Grove Dictionary of Music and Musicians. Ed. by L. Macy. (Accessed 3/21/09) http://www.newgrovemusic.com.

${ }^{80}$ Kennedy, 691.

${ }^{81}$ Silbiger, 128.
} 
Example 4.11 Elisabeth Jacquet de La Guerre (1665-1729): "Prelude" from Suite in G minor. Notice the absence of bar lines. ${ }^{82}$

Elisabeth Jacquet de La Guerre
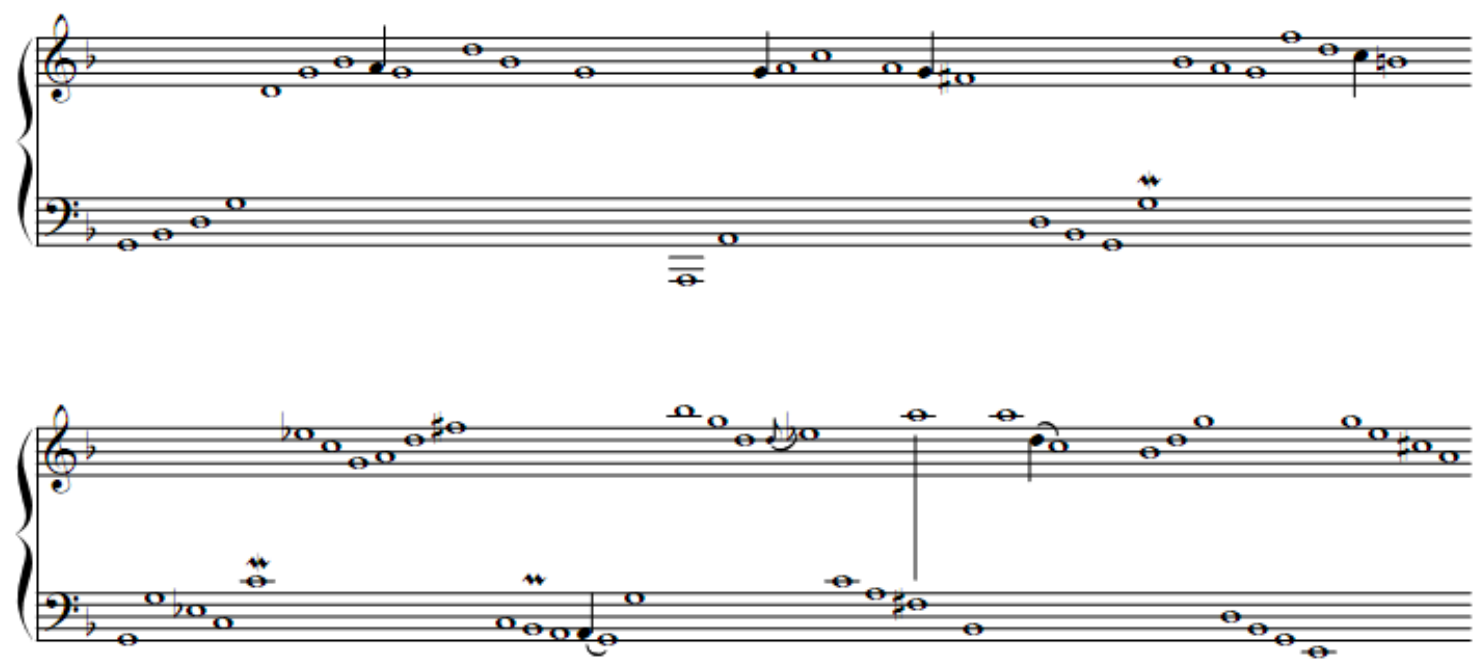

As demonstrated in the example above, the most typical notation for the unmeasured harpsichord prelude is a series of whole notes. These are unpretentious pieces, and they often were used as a beginner's first lesson. ${ }^{83}$

Some composers - notably, d'Anglebert and La Guerre - developed hybrid notations that included varied note values to distinguish ornamental notes, parallel to the semi-measured notation used for many lute preludes. More importantly, however, unmeasured notation was sometimes used for pieces of much greater musical substance, some of which were written under the clear influence of Froberger's toccatas. ${ }^{84}$

${ }^{82}$ IMSLP.

${ }^{83}$ Silbiger, 128.

${ }^{84}$ Ledbetter, "Prelude." 
Example 4.12 Froberger: Toccata No. 22 in C major. Notice the use of chords, arpeggios, and scale passages that might have appealed to the French when creating their own, highly improvisatory, unmeasured preludes. ${ }^{85}$

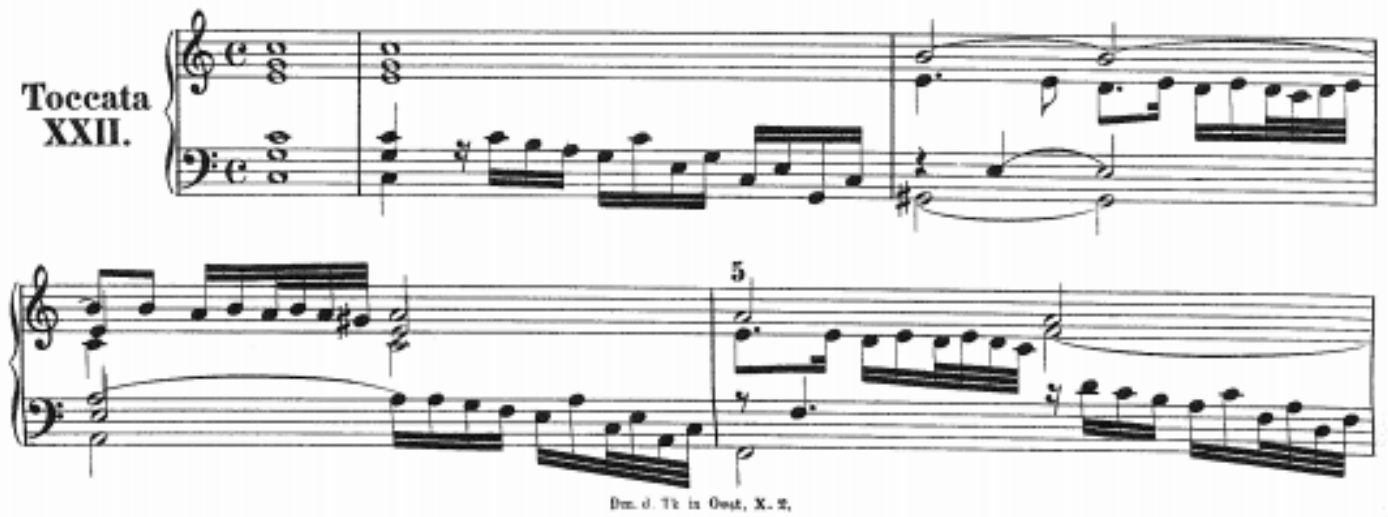

In Germany, Bach brought the keyboard prelude to the pinnacle of its development, both in its compositional quality and in its range of styles, manners, and formal prototypes. This is demonstrated masterfully in both volumes of his WellTempered Clavier (1722 and 1744) (BWV 846-893), incorporating elements of the ritornello principle of Antonio Vivaldi (1678-1741) and of the preludes from the Ariadne Musica of Fischer.

Bach brought the same level of quality, character, and principle to the preludes of his keyboard suites as well. Each of the English Suites begins with a prelude, and the separate Suite in A Minor (BWV 818a) also begins with a prelude. However, only two of the Partitas begin with preludes: Partita No. 1 opens with a "Praeludium" and Partita No. 5 opens with a "Praeambulum." 86

\footnotetext{
${ }^{85}$ IMSLP.

${ }^{86}$ Dürr, A. "The Historical Background of the Composition of J. S. Bach's Clavier Suites, Bach 16, No. 1 (1985).
} 
The "Praeludium" from Partita No. 1 represents an exceptional example of Bach's innovative techniques; it is relatively light in texture but ambitious in its scope. At its outset, it could easily be classified as a sinfonia or three-part invention, and the theme, accompanied in a broken style, reappears at the dominant in the bass (conclusion of $\mathrm{m}$. 4). From these humble beginnings this prelude eventually expands to five voices and concludes with a large-scale chord spanning four octaves. ${ }^{87}$ A prelude based on these dimensions was rare even for Bach let alone for any other composer of the day.

Example 4.13 Bach: "Praeludium” from Partita No. $1 .{ }^{88}$

\section{PARTITA I.}
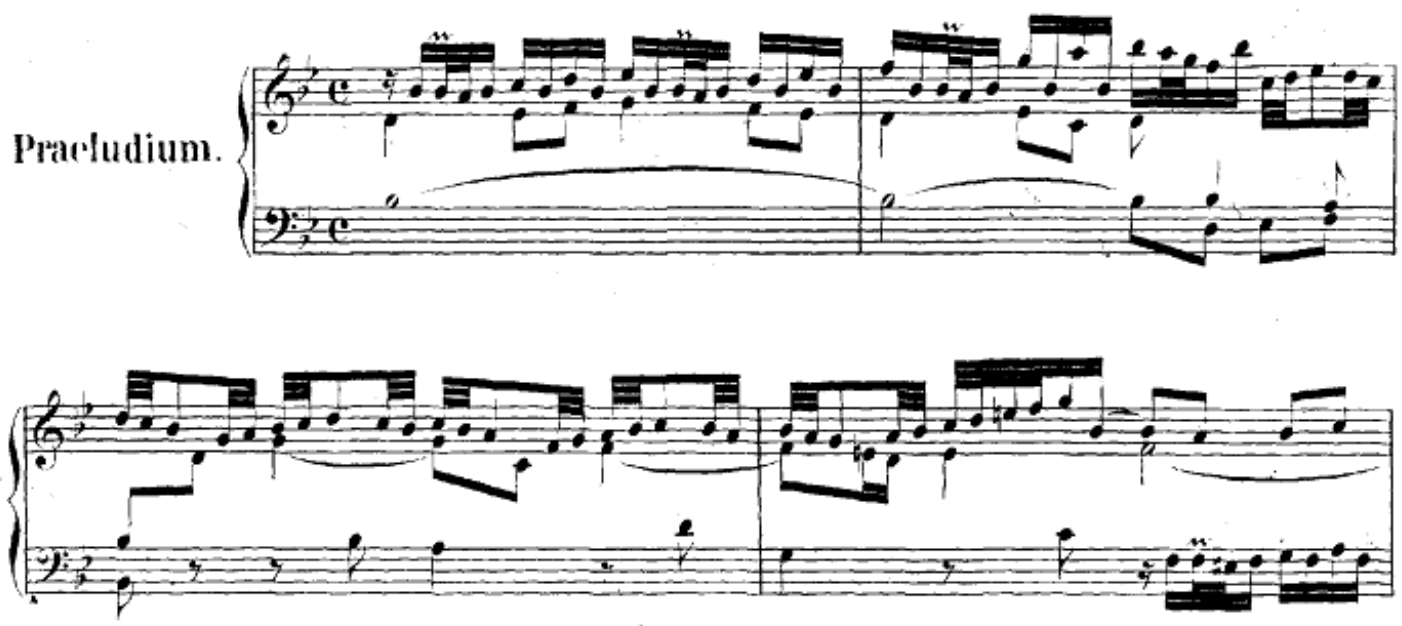

-Gavotte-

The gavotte is an old French dance in common time beginning on the third beat of a 4/4 bar. It originated in Pays de Gap where the inhabitants were known as "gavots." It was popularized at the court of Louis XIV, where Jean-Baptiste Lully (1632-1687)

${ }^{87}$ Schulenberg, 278-279.

${ }^{88}$ IMSLP. 
composed several orchestral examples. The gavotte also became an optional movement of the Baroque keyboard suite. ${ }^{89}$

Like most Baroque dances, the gavotte was used as both an instrumental and a vocal air as well as for dancing. Contemporary musicians thought the affect to be one of moderate gaiety - pleasant, tender, avoiding extremes of emotional expression. It was often considered a pastoral dance, an association emphasized in Bach's settings of gavottes in his English Suites for keyboard. The tempo varied according to the character of the piece and the amount of ornamentation..$^{90}$

Example 4.14 Bach: “Gavotte II” from English Suite No. 6. ${ }^{91}$

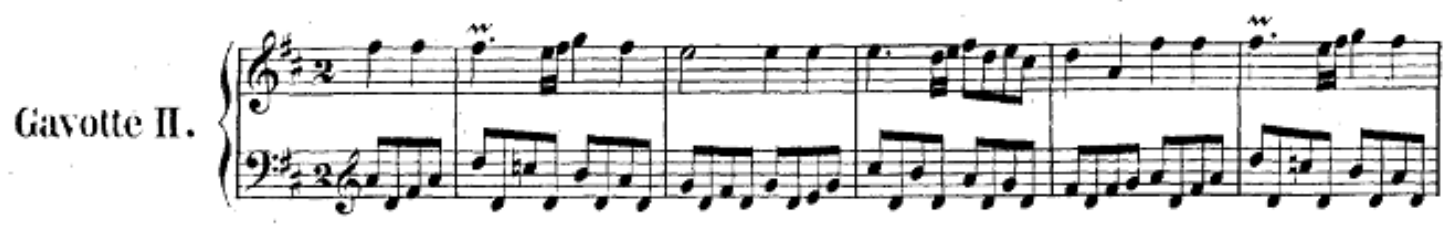

Jean-Jacques Rousseau (1712-1778) wrote that the gavotte, while usually a "gay" dance, could also be slow and tender. Unlike the more serious Baroque dances, such as the allemande and courante, the gavotte never lost its relative simplicity of texture and clear phrasing. Gavottes were most often written in binary form, or as a set of variations. Occasionally two gavottes occurred consecutively in a suite, the first then repeated da capo. $^{92}$

\footnotetext{
${ }^{89}$ Kennedy, 333.

${ }^{90}$ Kennedy, 334.

${ }^{91}$ IMSLP.

${ }^{92}$ Little, M. "Gavotte." The New Grove Dictionary of Music and Musicians. Ed. by L. Macy. (Accessed 1/4/10) http://www.newgrovemusic.com.
} 
-Bourrée-

The bourrée was a French folk dance, court dance, and instrumental form, which flourished from the mid-17th Century until the mid-18th. The word was typically spelled "bourée" in French; the preferred current spelling may be of German origin. As a folkdance it had many varieties, and dances called bourrée are still known in various parts of France; in Berry, Languedoc, Bourbonnais, and Cantal the bourrée is a duplemeter dance, while in Limousin and the Auvergne it is commonly in triple meter.

Many historians, including Rousseau, believed that the bourrée originated in the Auvergne as the characteristic Branle of that region (branles are mentioned in Chapter III), but others have suggested that Italian and Spanish influences played a part in its development. It is not certain if there is a specific relationship between the duple French folkdance and the court bourrée.

Baroque keyboard versions of the bourrée often took liberties with the original simplicity of the dance form. Such composers as Lebègue, d'Anglebert, Purcell, Gottlieb Muffat (1690-1770), Bach, and Domenico Scarlatti (1685-1757) wrote bourrées, many highly ornamented with virtuosic display of keyboard technique. ${ }^{93}$

The “Bourrée I" from Bach's English Suite No. 1 (listed as example 4.15 below) both maintains and departs from the typical bourrée described above. It is longer and more contrapuntal than many of those by his contemporaries or those by Fischer, from whom he probably got his first examples. However, the slurs serve to sustain the

\footnotetext{
${ }^{93}$ Little, M. "Bourrée," The New Grove Dictionary of Music and Musicians. Ed. by L. Macy. (Accessed 1/6/10) http://www.newgrovemusic.com.
} 
underlying quarter-note rhythm of the dance and also create a two-note "sigh" motive that preserves the pastoral character of the original folkdance. ${ }^{94}$

Example 4.15 Bach: "Bourrée I" from English Suite No. 1. ${ }^{95}$

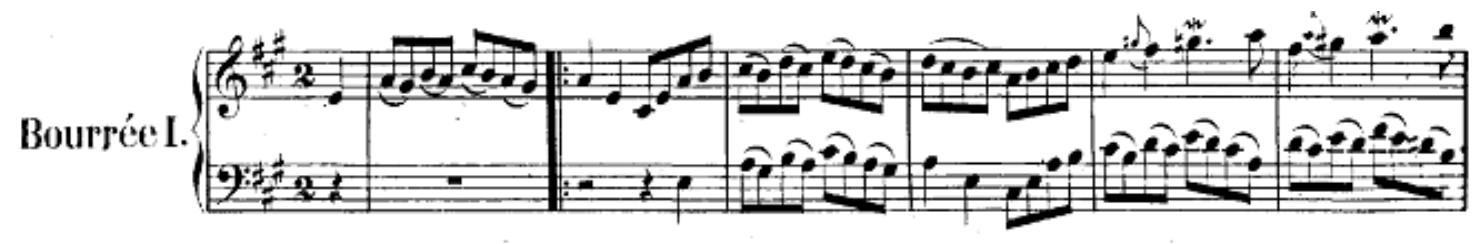

-Minuet-

Though the origin of the minuet is unknown, it was danced in the court of Louis XIV at least by mid-1 $7^{\text {th }}$ Century. Michael Praetorius (1571-1621) (Terpsichore, 1612) is now thought to have erred in claiming it to be a descendant of the branle de Poitou, a claim that was nonetheless repeated over a century later by Pierre Rameau (1674-1748, no relation to Jean-Philippe Rameau) (Le maître à danser, 1725), with the addition of the plausible detail that Pierre Beauchamp (1631-1705), Louis XIV's dancing-master, had effected the transformation from branle to minuet. The name "menuet" may have been derived from the French "menu" (slender, small), referring to the extremely small steps of the dance, or from the branle à mener or amener, which, like the branle de Poitou, were popular group dances in early $17^{\text {th }}$-Century France.

Like most $17^{\text {th }}$-Century dances, the minuet was included in French keyboard suites, usually (along with other still-popular dances like the bourrée and gavotte) appearing after the sarabande. Many composers included minuets among their

\footnotetext{
${ }^{94}$ Schulenberg, 240-241.

${ }^{95}$ IMSLP.
} 
independent keyboard pieces (e.g., Chambonnières, Lebègue, Louis Marchand (16691732), and Bach in the minuets in the Notenbüchlein für Anna Magdalena Bach).

Usually, the minuet received a rather straightforward compositional treatment, with its characteristic clarity of rhythm and phrase preserved. Even the occasional double (variation) of a minuet was likely to be free from the complex texture and rhythmic ambiguities that otherwise preoccupied instrumental composers of the French Baroque, probably because the minuet was still a familiar social dance. ${ }^{96}$

Example 4.16 Bach: "Menuet I" from English Suite No. $4 .^{97}$

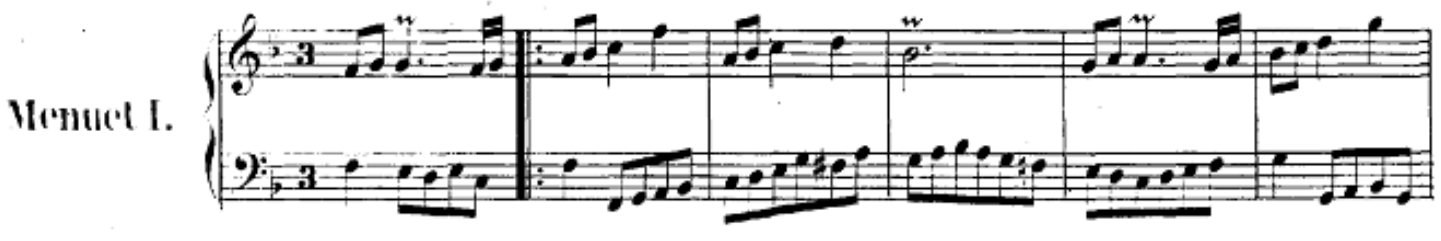

-Chaconne-

Most chaconnes are in triple meter, with occasional exceptions, and they often consist of an arbitrary number of comparatively brief units, usually of two, four, eight, or sixteen measures, each ending with a cadence that leads without a break into the next unit. Like the sarabande, the chaconne originated in the New World during the 16th century and was brought to Spain by sailors from the Yucatan peninsula in Mexico. ${ }^{98}$ No examples are extant from this period, but references by Cervantes, Vega, Francisco Gómez de Quevedo (1580-1645), and other writers indicate that the chacona was a

\footnotetext{
${ }^{96}$ Little, M. "Minuet," The New Grove Dictionary of Music and Musicians. Ed. by L. Macy. (Accessed 1/6/10) http://www.newgrovemusic.com.

${ }^{97}$ IMSLP.

${ }^{98}$ Beaussant, P. François Couperin. Trans. by A. Land. (Portland: Amadeus Press, 1990), 267.
} 
dance-song associated with servants, slaves, and Amerindians. Like the zarabanda, it was often condemned for its suggestive movements and mocking texts, which spared not even the clergy, and was rumored to have been invented by the devil. Its high spirits were expressed in the refrains that appeared in its often lengthy texts, usually beginning with some variant of "Vida, vida, vida bona!/Vida, vámonos á Chacona!” (which can be freely translated as: "Let's live the good life; let's go to Chacona!"').99

The keyboard ordres of François Couperin provide some excellent examples of chaconnes despite the fact that the composer wrote relatively few of them. Additionally, his uncle, Louis Couperin, was fond of the chaconne, and many of his examples are preserved. ${ }^{100}$ Perhaps François Couperin, who had access to his uncle's manuscripts, was able to incorporate the best of what his uncle had to offer in addition to his own creativity and historical understanding. He even wrote a chaconne in duple meter, something he considered remarkable enough to mention in the score: ${ }^{101}$

\footnotetext{
${ }^{99}$ Silbiger, A. "Chaconne," The New Grove Dictionary of Music and Musicians. Ed. by L. Macy. (Accessed 1/7/10) http://www.newgrovemusic.com.

${ }^{100}$ Beaussant, 243.

${ }^{101}$ Silbiger, "Chaconne."
} 
Example 4.17 François Couperin: "Chaconne a deux tems" from Ordre No. 3, "La Favorite."

La Favorite.
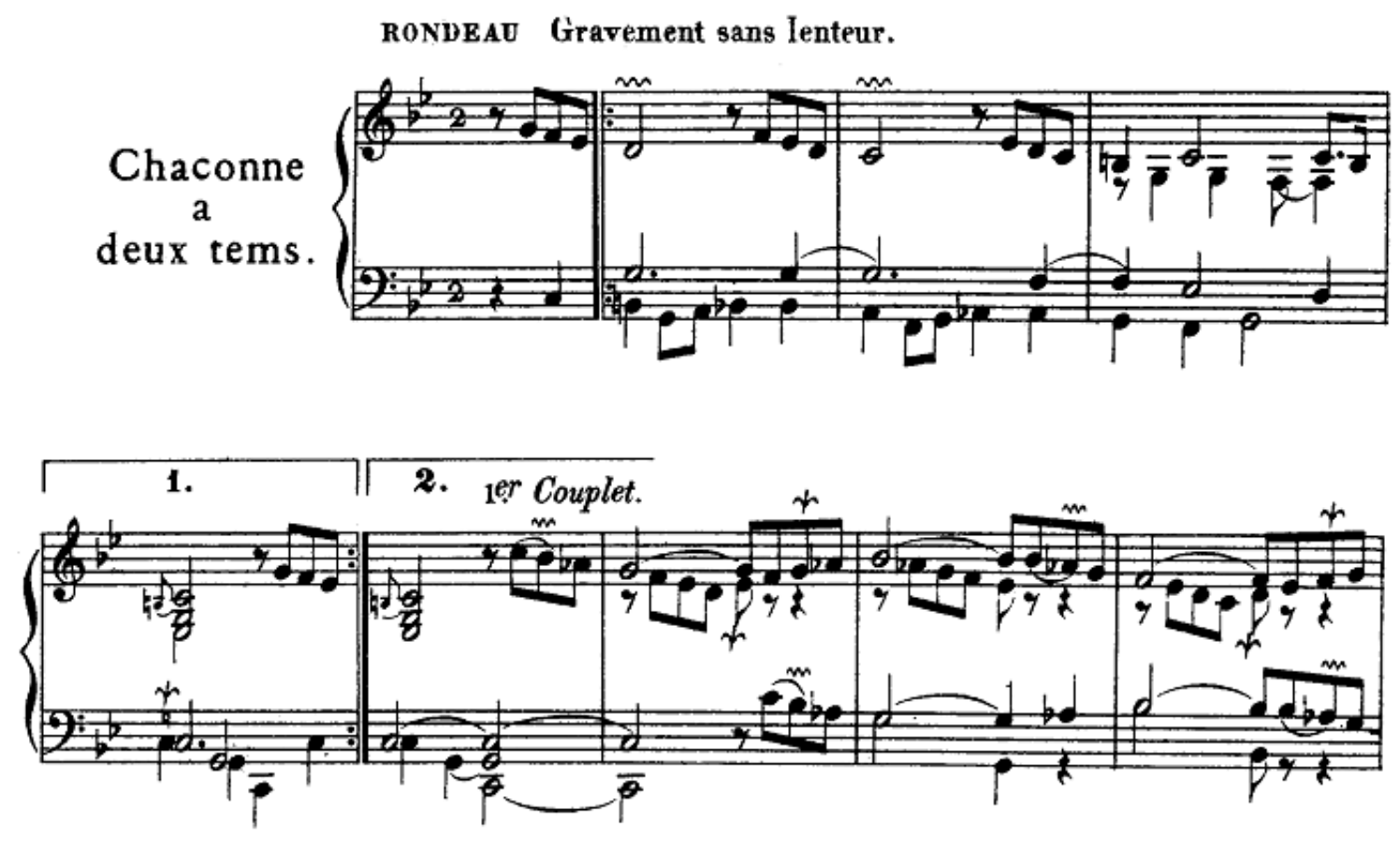

-Passepied-

The passepied is normally associated with the French but was originally an English dance: "Paspy" or "pass-foot." It is said to have originated among sailors and was then introduced to Paris by street dancers in the late $16^{\text {th }}$ Century. ${ }^{103}$ As we know it today, the passepied is a French court dance and instrumental form that flourished in the 17 th and 18th Centuries. It was essentially a faster version of the minuet, usually written in $3 / 8$ or $6 / 8$ with an upbeat, and having two sections, four-bar phrases, and fairly constant movement. It was frequently used in French opera and ballet, often in pastoral scenes, as well as in orchestral and keyboard suites of the mid- and late Baroque era.

\footnotetext{
102 IMSLP.

${ }^{103}$ Kennedy, 659.
} 
These passepieds usually appeared in pairs, the first to be repeated (da capo) after the second was played. ${ }^{104}$

Instrumental pieces entitled "Passepied" and showing the dance's characteristic rhythm and phrase structure appeared in many 17 th- and 18th-Century suites and overtures. As mentioned above, the music is usually in $3 / 8$ time, with an upbeat, and long phrases in a length divisible by four measures.

Bach composed passepieds for keyboard in his English Suite No. 5, the Partita No. 5, and the Overture in the French Style:

Example 4.18 Bach: "Passepied" from the Overture in the French Style. ${ }^{105}$

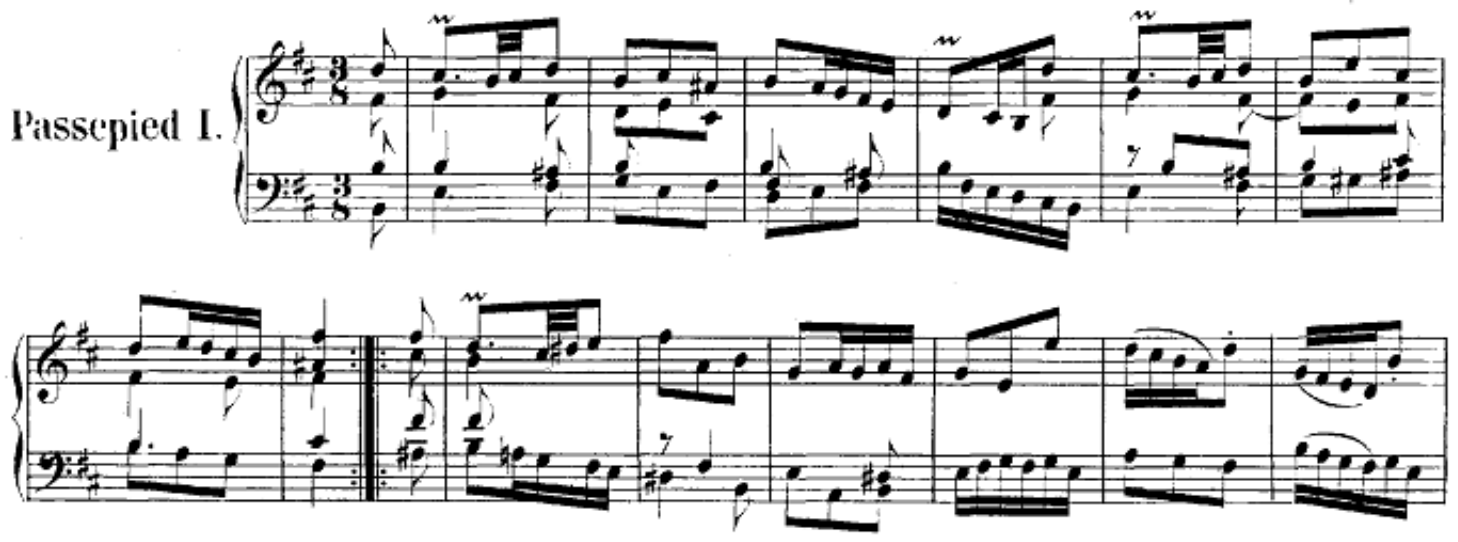

Other instrumental composers who favored the passepied include Gaspard Le Roux (1660-1706) (Pièces de Clavecin, 1705) and Fischer (Musicalisches BlumenBüschlein, 1698): ${ }^{106}$

\footnotetext{
${ }^{104}$ Little, M. "Passepied," The New Grove Dictionary of Music and Musicians. Ed. by L. Macy. (Accessed 1/6/10) http://www.newgrovemusic.com.

${ }^{105}$ IMSLP.

${ }^{106}$ Little, "Passepied."
} 
Example 4.19 Le Roux: "Passepied" from Suite in D minor. ${ }^{107}$

\section{Passepied}

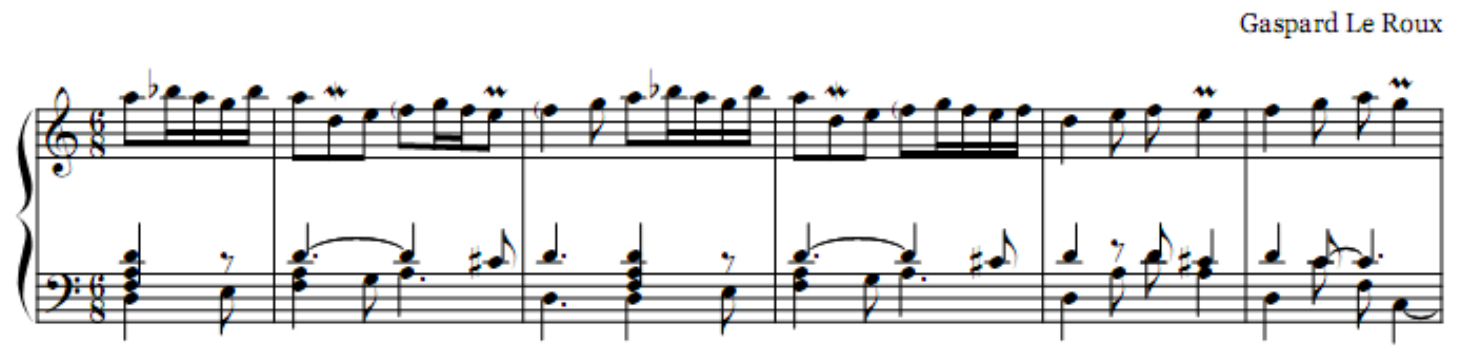

-Rigaudon-

The rigaudon was a French folkdance, court dance, and instrumental form popular in France and England in the 17th and 18th Centuries. As a folkdance it was traditionally associated with southern France, especially the provinces of Vavarais, Languedoc, Dauphiné and Provence, although the term is now used to refer to a wide variety of folkdances from several regions. The popularity of the dance seems to have spread quickly from Paris and Versailles to England and Germany. ${ }^{108}$

Many instrumental rigaudons for harpsichord and ensemble show the characteristic harmonic and melodic rhythms and clear phrase structure of the original folkdance. Their form was usually either that of successive unrelated strains or, more typically in the 18th Century, a rounded binary form. A rigadoon by Purcell shows the adoption of a melodic rhythm similar to that found in more traditional rigaudons, minus

\footnotetext{
${ }^{107}$ IMSLP.

${ }^{108}$ Little, M. "Rigaudon," The New Grove Dictionary of Music and Musicians. Ed. by L. Macy. (Accessed 1/8/10) http://www.newgrovemusic.com.
} 
the characteristic upbeat and long notes at the beginnings of phrases but retaining the harmonic shape of the phrase. ${ }^{109}$

Example 4.20 Purcell: “Rigadoon” from Musick’s Hand-Maid. ${ }^{110}$

\section{Rigadoon}

\section{Z. 653}
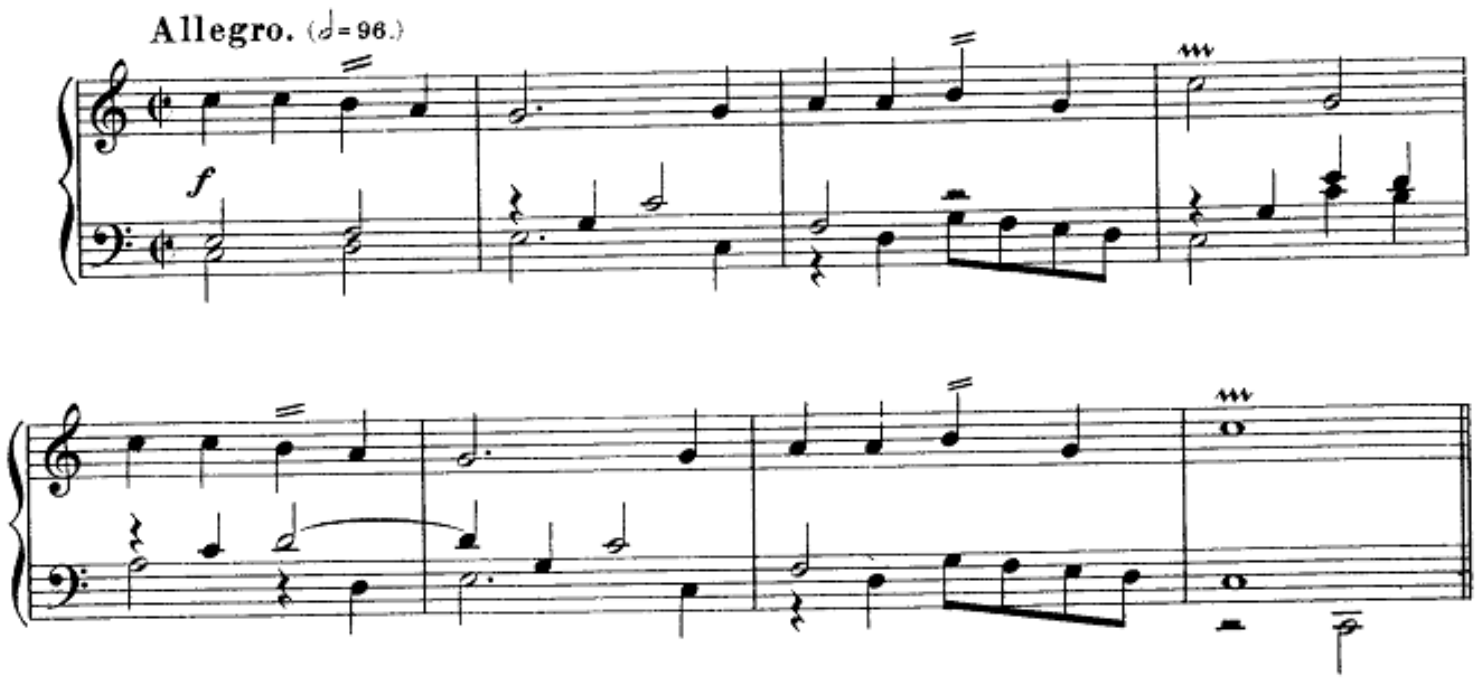

Other keyboard composers who wrote rigaudons were La Guerre, Daquin,

Fischer, Pachelbel, François Couperin, and Rameau:

Example 4.21 François Couperin: "Rigaudon" from Ordre No. 2. ${ }^{111}$

Rigaudon

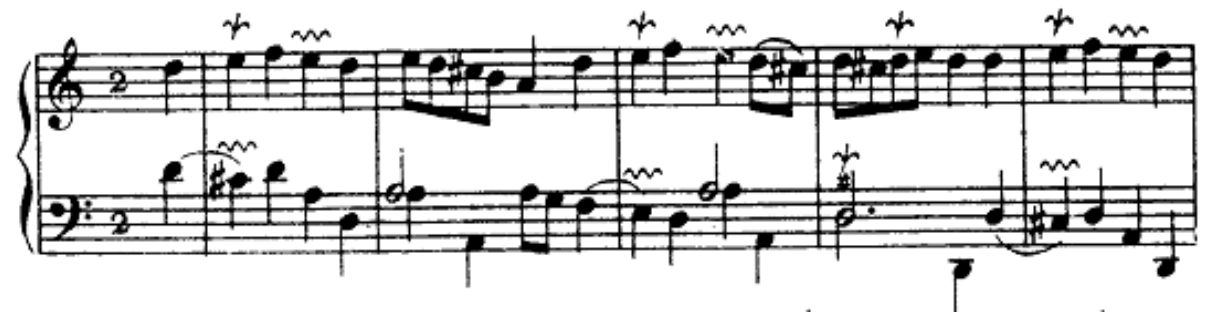

\footnotetext{
${ }^{109}$ Little, "Rigaudon."

${ }^{110}$ IMSLP.
}

${ }^{111}$ IMSLP. 
One of the most fundamental designs in music, the rondo is a structure consisting of a series of sections, the first of which (the main section or refrain) recurs, normally in the home key, between subsidiary sections (couplets, episodes) before returning to conclude, or round off, the composition $(A B A C \ldots A) .{ }^{112}$

The simplicity of the rondo concept, and its wide usage, make it difficult to give a precise account of its origins. Those few 18th-century theorists who mentioned influences on the rondo used such popular examples as the Frantzösischer Ringel-Tantz (Walther), the Kreiz or Circul-Tantz (Niedt), the Zirckelstück (Marpurg, Türk), and the Rundgesang (Türk). Mattheson noted that although "rondeau" does indeed derive from "rond" or "rund" (circle), the music applied to this term originates neither in the circle-dance nor in the Runda (a relative of the French ronde de table), a type of drinking-song in which a rousing refrain sung by all the merrymakers followed each participant's verse. ${ }^{113}$

In terms of keyboard composition, François Couperin was the unrivalled master of the harpsichord rondeau, of which there are many examples in his ordres; like most of his movements, they often bear fanciful titles (such as "Les Baricades Mistérieuses"):

\footnotetext{
${ }^{112}$ Cole, M. "Rondo," The New Grove Dictionary of Music and Musicians. Ed. by L. Macy. (Accessed 1/8/10) http://www.newgrovemusic.com.

${ }^{113}$ Cole, "Rondo."
} 
Example 4.22 François Couperin: "Rondeau" from Ordre No.6, "Les Baricades Mistérieuses." $" 114$

\section{Les Baricades Mistérieuses.}
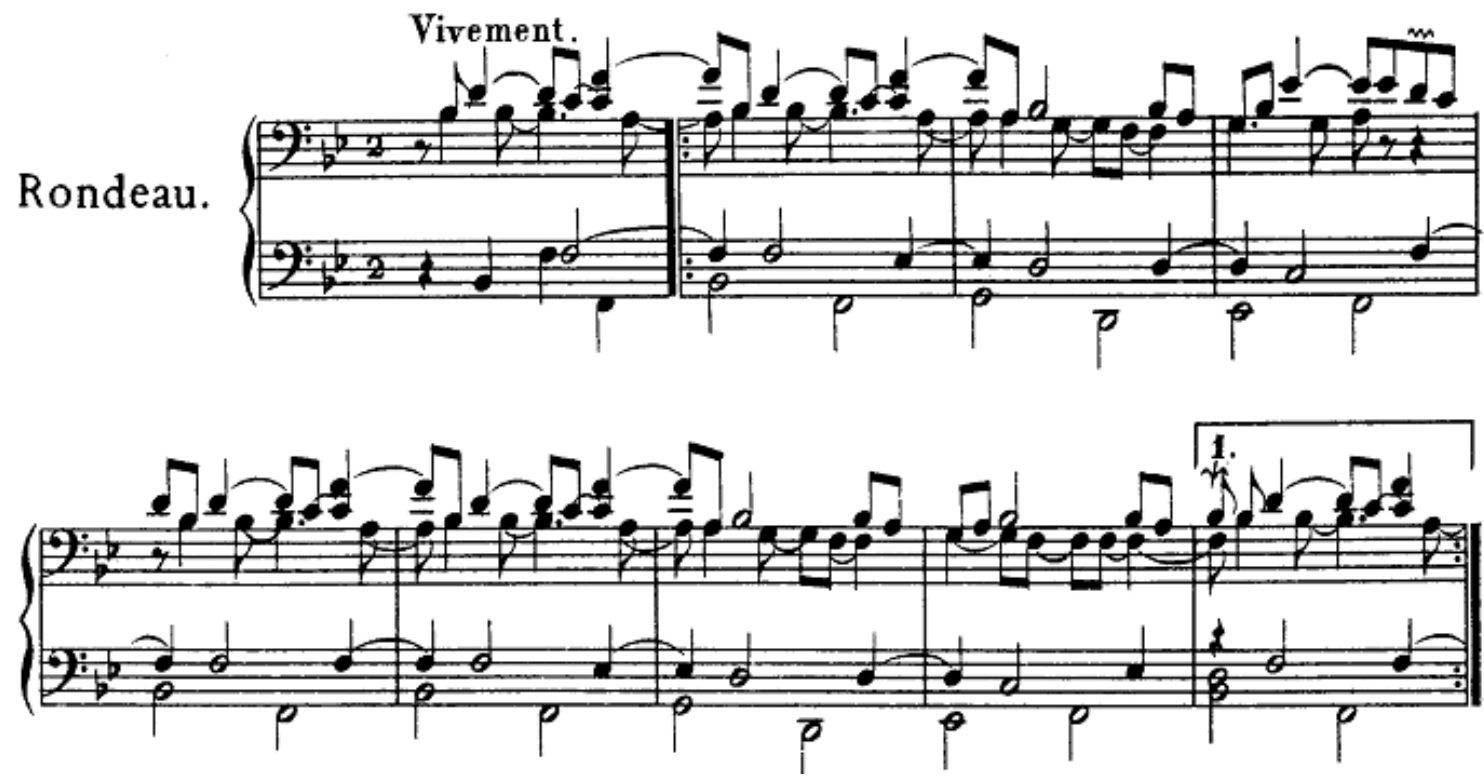

As we have seen, the suite and its various components existed well before their incorporation into keyboard music, and their roots are wide-ranging, coming from as far away as Latin America. The dances we have discussed here are among those most commonly found in keyboard suites of the $17^{\text {th }}$ and $18^{\text {th }}$ Centuries. My next step is to address the keyboard suite as it developed in France, England, and Germany.

${ }^{114}$ IMSLP. 


\section{Chapter V}

\section{The French Keyboard Suite}

This chapter will serve as a survey of the development of the Baroque keyboard suite in France and will also discuss the major composers and manuscript collections that contributed to that development. During the Baroque Era, most French composers of

keyboard music used the suite as their primary genre ${ }^{115}$, but only a few composers can be discussed at length in this project. I shall first focus on the development of keyboard suites in France during the $17^{\text {th }}$ Century and the composers associated with that development. Then I shall discuss the first half of the $18^{\text {th }}$ Century in a similar fashion: Some of the more important composers I shall touch upon include but are not limited to d'Anglebert, Chambonnières, Rameau, Louis Couperin, Marchand, La Guerre, Nicolas Clérambault (1676-1749), and Lebègue among others. However, as is the case with Bach in Germany, one figure looms large in the French harpsichord suite: François Couperin. In some ways, it appears that much of the keyboard suite writing that came before Couperin ultimately led to his masterful and beautifully written works in that genre. This overview of the French contribution to the development of the keyboard suite will ultimately allow us to move into the chapters dealing with England and Germany with greater understanding.

${ }^{115}$ Silbiger, A. Ed. Keyboard Music Before 1700. (New York: Routledge, 2004), 124. 


\section{-Manuscript Collections-}

Before discussing the publications of French keyboard composers, I shall briefly delve into the manuscript collections that circulated throughout France during the $17^{\text {th }}$ Century. These manuscripts contained compositions written well before the first publications that took place around 1670 and also included works from other composers on the continent. Despite the sometimes-confusing organization of these collections, their value to those attempting to understand the contemporary French attitude and general approach to composition of the day is huge.

As stated above, the suite was the primary genre employed by composers of Baroque French harpsichord music; however, there is little evidence that French keyboard performers/composers of the day conceived the suite as a compositional unit intended for ordered performance at a single sitting. In fact, suites often were not copied from one manuscript to another as units. Silbiger has offered one explanation for this lack of cohesion: “... perhaps these were just performance orderings." "116

Thus, it would appear that professional musicians compiled their own suites from previously existing pieces, creating manuscripts that present groups of dances by more than one composer. Parville is one such manuscript that has survived to this day. There are also manuscripts that present, in effect, anthologies of dances; in some, there is no organization at all, and in others the movements are grouped by tonality and in the general order of a "classical" suite, but in quantities that make treating them as a performance unit an impossibility. ${ }^{117}$

\footnotetext{
116 Silbiger, 124.

117 Silbiger, 124.
} 
Along with Parville, the Bauyn manuscript is another important source for early French harpsichord music. It was compiled around 1690, when the only published harpsichord pieces were those by Chambonnières, Lebègue, and d'Anglebert. Included in it are almost all known harpsichord pieces by Louis Couperin and Chambonnières, more than 20 pieces by Froberger, and music by several other composers, including Michel de La Barre (1675-1745), Jacques Hardel (1643-1678), and Frescobaldi. However, all of the pieces in the Bauyn manuscript are grouped according to dance genre, not in suites. One possible explanation for this grouping is that the Bauyn manuscript was most likely copied by a professional anonymous scribe who chose to organize the manuscript in this way for his own convenience. ${ }^{118}$

Example 5.1 Bauyn manuscript: detail of a piece by Louis Couperin, showing both conventional and free notation. ${ }^{119}$

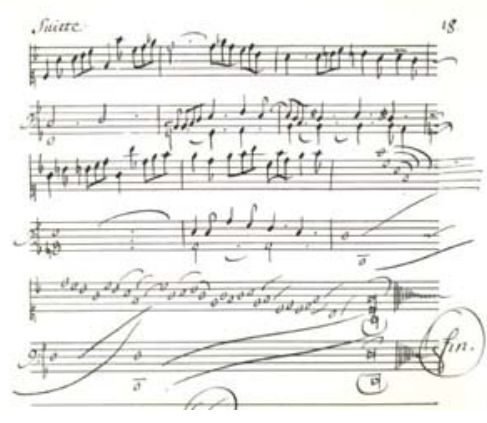

$-17^{\text {th }}$-Century French Keyboard-Suite Structure-

Among prominent French keyboard composers who prepared their works for publication, a $17^{\text {th }}$-Century suite was understood to consist of the "core" movements A-

${ }^{118}$ Silbiger, 122.

${ }^{119}$ OMI www.omifacsimilies.com (Accessed 8/18/09). 
C-S, with the optional preface of an unmeasured prelude. Some of the core dances, particularly the courante, were also doubled; the dances that followed usually included a gigue, and often a minuet provided a conclusion. In essence, the classic sequence of A-C$\mathrm{S}$ is the skeleton of the French harpsichord suite, but not its body. ${ }^{120}$

What set the French harpsichord suite apart from those being composed by other Europeans, besides the doubling of dances, was the inclusion of additional dances following the gigue. Instead of finishing their suites with a gigue, French composers chose three, four, or more dances from a list, at the top of which stood the gavotte and minuet, followed by the bourrée, canary, chaconne, and others. Gavottes, minuets, and other popular dances often came in pairs, and the second of the pair was sometimes in the parallel mode or, rarely, in a different key. ${ }^{121}$

This pairing of dances within the suite, probably derived from ballroom practice, does not appear before the time of Lebègue, who may have been the first to introduce key contrast into the suite. The order within the closing group, as well as its size, appears to have been arbitrary; but the last piece, more often than not, was a minuet. ${ }^{122}$ Below is an example by La Guerre in which she places two rigadouns in succession within one suite.

\footnotetext{
${ }^{120}$ Silbiger, 122.

${ }^{121}$ Fuller, D. "Suite," The New Grove Dictionary of Music and Musicians. Ed. by L. Macy. (Accessed 11/14/07) http://www.newgrovemusic.com.

${ }^{122}$ Fuller.
} 
Example 5.2 La Guerre: First and Second "Rigadouns" from Suite in D minor in Pièces de Clavecin. Notice the shift from D minor to D major. ${ }^{123}$

\section{Rigadoun}

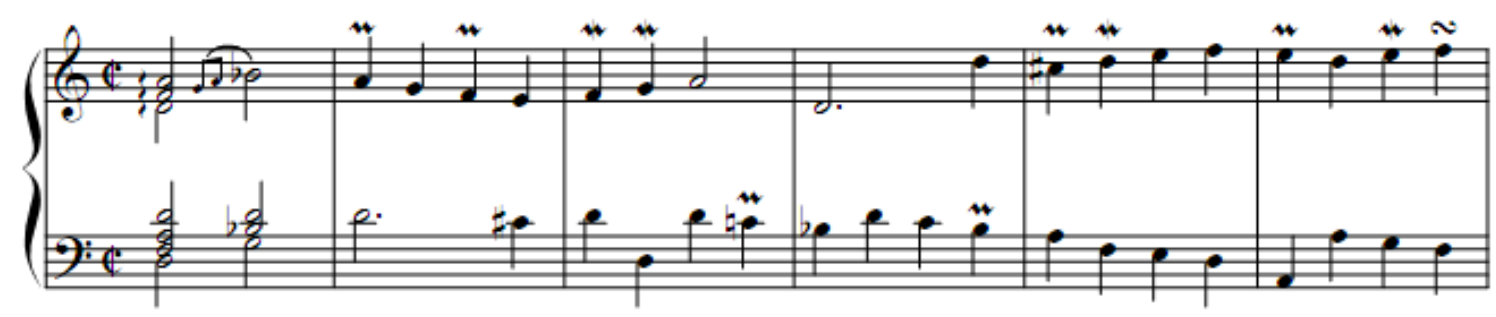

\section{2e Rigadoun}

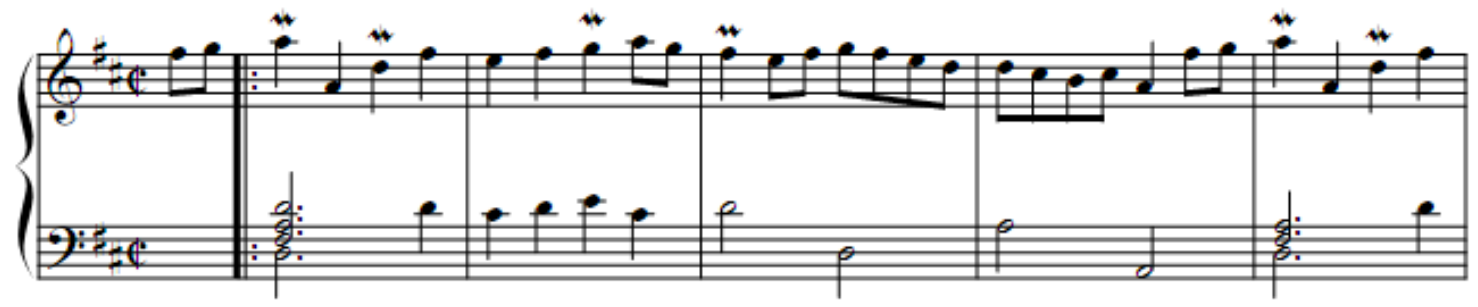

-The School of Chambonnières-

The three earliest published composers mentioned above: Chambonnières, d'Anglebert, and Lebègue, printed several books entitled Pièces de Clavecin between 1670 and 1690. Each book contains suites that range anywhere from four to twenty-one movements in length. Over half begin with unmeasured preludes (one of these is called a tocade), and all but two have an allemande as the first dance; the exceptions are in suites by Chambonnières in which a pavane provides a stately beginning. ${ }^{124}$

\footnotetext{
${ }^{123}$ IMSLP [International Music Score Library Project]/ Petrucci Music Library. (Accessed 4/3/09) http://imslp.org/wiki/Main_Page.

${ }^{124}$ Silbiger, 124.
} 
Example 5.3 Chambonnières: "Pavane L'entretien des Dieux" from Pièces de Clavecin, Book I. ${ }^{125}$

\section{Pavane L'entretien des Dieux}
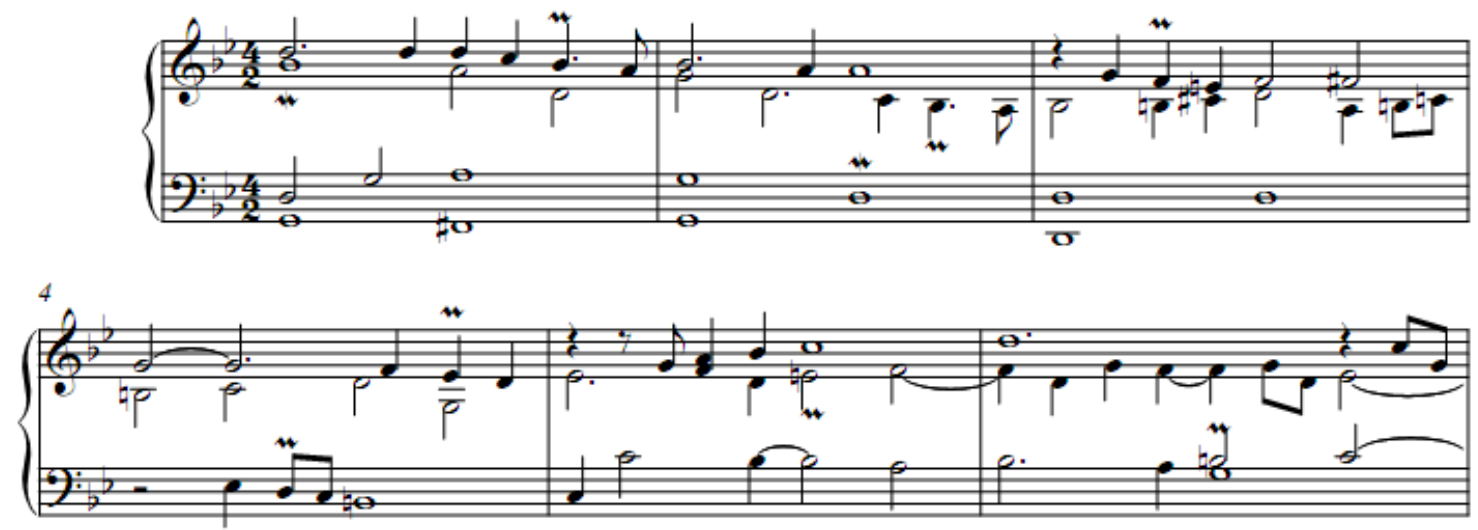

Clearly, when these composers prepared works for public consumption, they ordered them in performing units, and these are our best guides to French composers' intentions regarding the harpsichord suite in the Baroque Era. That the published groupings were intended as performing orders was made explicit by d'Anglebert in a note explaining that "one plays" the gigue added at the end of a group of transcriptions after the first gigue of the suite. ${ }^{126}$

Some composers had even more specific notions of suite design. La Guerre placed the gigue directly after the sarabande in all of her suites, as did Marchand. Lebègue tended to end his suites with a minuet, as did La Guerre in all four of her suites and Marchand in his. However, the most exceptional suites are those by d'Anglebert in

\footnotetext{
${ }^{125}$ IMSLP.

${ }^{126}$ Silbiger, 124.
} 
which a group of transcriptions or other "miscellaneous" pieces (a set of variations on les folies d'espange or an honorific tombeau) conclude or are appended to the suite. ${ }^{127}$

Example 5.4 d'Anglebert: "Tombeau de Mr. de Chambonnières" appended to his Suite in $D$ major. This is obviously a piece in homage to the great French harpsichord master. $^{128}$

92

\section{Tombeau de Mr. de Chambonnieres}
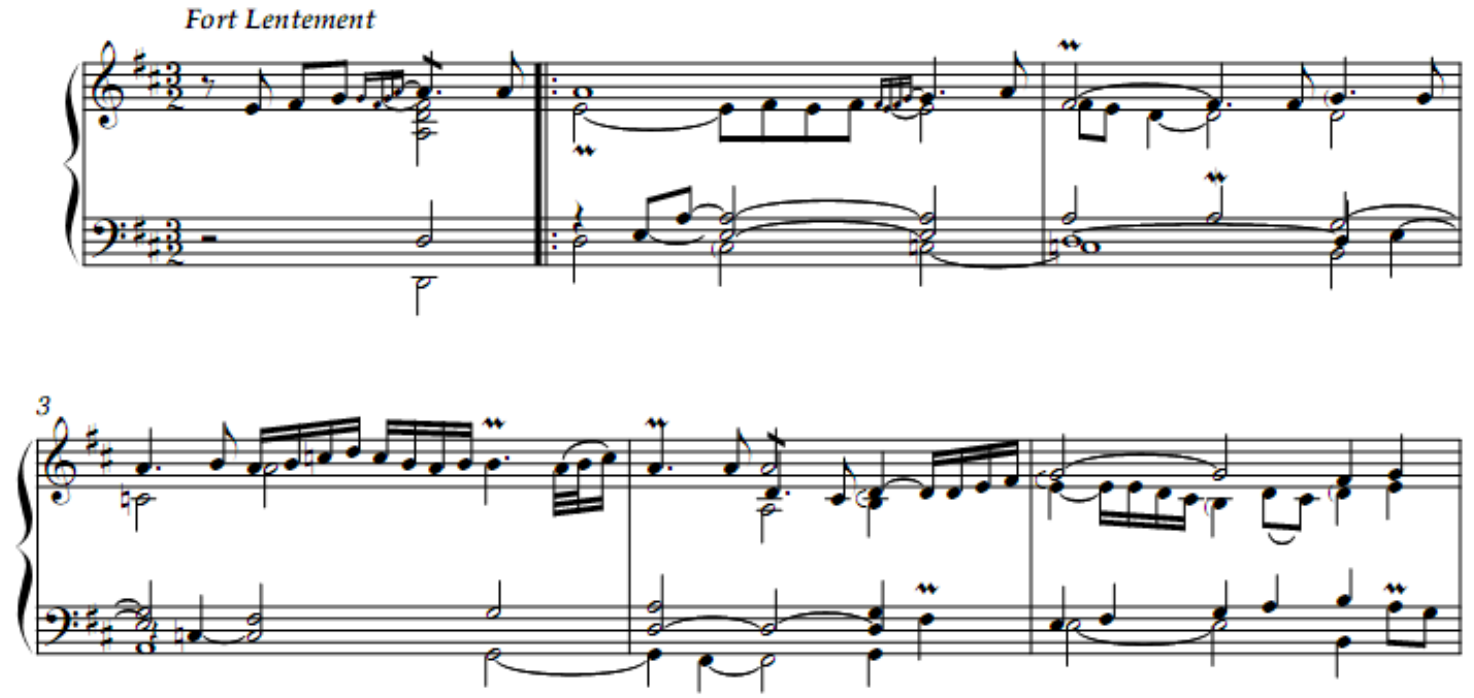

One of the earliest major contributors to the French keyboard suite in the $17^{\text {th }}$ Century was Chambonnières, who also taught a number of students; they in turn made significant contributions of their own to the literature. In 1670, two years before his death, Chambonnières published a selection of 60 pieces, divided into two volumes, arranging them in groups (presumably intended as suites). Most of these suites are based on the A-C-S model, and two conclude with a gigue. Many of these pieces were probably composed in the 1640s. What is completely unknown, however, is whether they were

${ }_{128}^{127}$ Silbiger, 126.

${ }^{128}$ IMSLP. 
originally conceived as members of suites, or even whether they ever circulated as such prior to publication. ${ }^{129}$

Example 5.5 Chambonnières: "Sarabande Jeunes Zephirs" from Pièces de Clavecin, Book II (1670). ${ }^{130}$

\section{Sarabande Jeunes Zephirs}

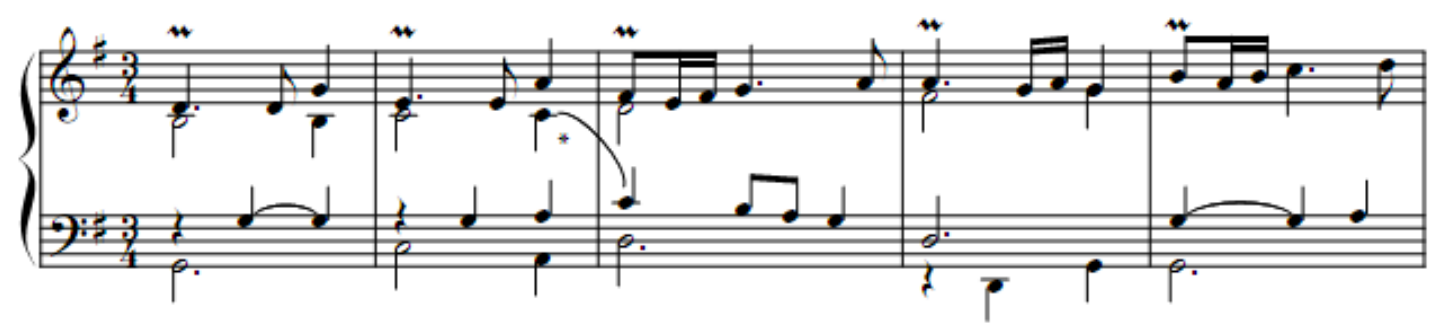

A slightly more informative situation exists for the works of Chambonnières's brilliant pupil, Louis Couperin (uncle of François Couperin), whose untimely death - 35 years of age - provides an unfortunate ending for his approximately 135 keyboard pieces. Not only is most of Louis Couperin's keyboard music preserved, but also major musicologists, such as Fuller, view his works as generally being of higher quality than those of his teacher. ${ }^{131}$

However, a contemporary musicologist of the day, Sieur Pierre Le Gallois (fl. 1672-1680), tells us that Hardel was the best student and musical heir of Chambonnières. Hardel carried on the style and, in Le Gallois's judgment, was fully the equal of the master. Unfortunately, only a small handful of Hardel's pieces survive, but they are

\footnotetext{
${ }^{129}$ Parker, M. "Some Speculations on the French Keyboard Suites of the Seventeenth and EarlyEighteenth Centuries," International Review of the Aesthetics and Sociology of Music Vol. 7, No. 2 (1976). ${ }^{130}$ IMSLP.

${ }^{131}$ Fuller.
} 
indeed fine works. There is a six-movement suite, a courante, and what became one of the more popular tunes of the $17^{\text {th }}$ Century, a gavotte to which Louis Couperin wrote a double. $^{132}$

-The $18^{\text {th }}$-Century French Keyboard Suite-

In the early part of the $18^{\text {th }}$ Century, French suites were usually still preceded by a prelude, or by an ouverture. The preludes employed both whole-note (i.e., unmeasured) and rhythmic notations. During the $17^{\text {th }}$ Century the prelude, in its purest form, had been written out entirely in whole-notes, and the performer was given complete liberty to interpret the harmonic and melodic implications of the notation. The very nature of the unmeasured prelude, then, assured that every performance would be, in effect, improvisatory and unique. During the course of the $18^{\text {th }}$ Century, however, prelude composers increasingly imposed more constraints on the performer's freedom until the unmeasured form was eventually abandoned. ${ }^{133}$

During the early $18^{\text {th }}$ Century the French suite consisted of a more or less fixed "core" of four dances - A-C-S-G - although their order could vary. However, as was the case in the $17^{\text {th }}$ Century, other dances and movements were often added to the end of the basic core. The most common additions were menuets and gavottes; other movements included chaconnes, passacailles, rigaudons, and rondeaux. Like the four core dances, they are usually in simple binary form, but examples of rounded binary, ternary, rondeau, and even sonata form are also represented. ${ }^{134}$

\footnotetext{
${ }^{132}$ Fuller.

${ }^{133}$ Fuller.

${ }^{134}$ Silbiger, 126.
} 
The dances generally resembled their $17^{\text {th }}$-Century counterparts but encompassed a wider stylistic range. The sarabande, for example, was no longer necessarily a slow dance or a rapid and exotic one: Le Roux wrote a sarabande in D major that was simply marked "gaye." And the gigue now appears in two distinct types: the Italian form, in rapid $6 / 8$ or $12 / 8$ time, with prevailing rhythmic motion in eighth-notes, and the French form, in $6 / 4$ time, and more complex in rhythm. ${ }^{135}$

Example 5.6 Clérambault: "Gigue" from Suite in C minor in Pièces de Clavecin, Book I (1704). Here is an example of an Italian gigue by Clérambault. ${ }^{136}$

\section{Gigue}

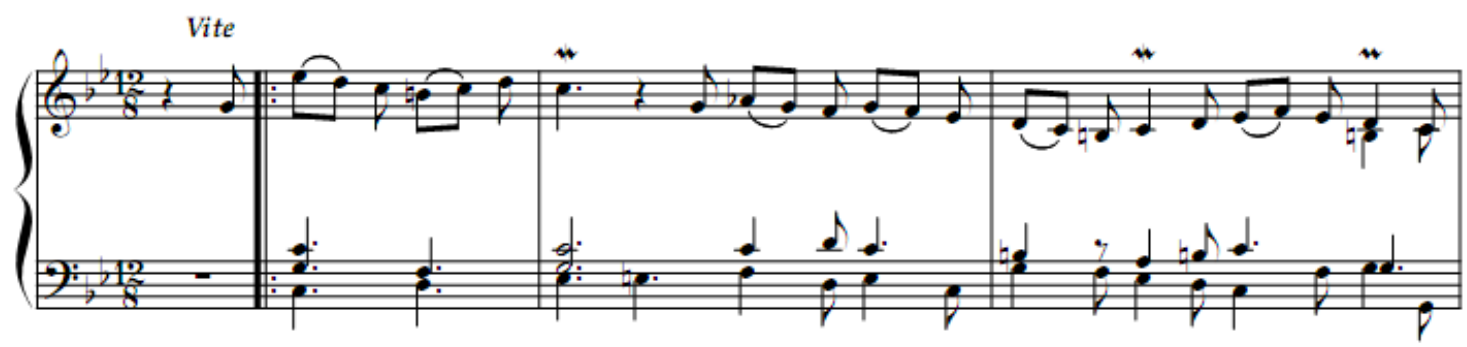

Example 5.7 Clérambault: "Gigue" from Suite in C major in Pièces de Clavecin, Book I. Here is an example of a French gigue by the same composer. ${ }^{137}$

\section{Gigue}

10

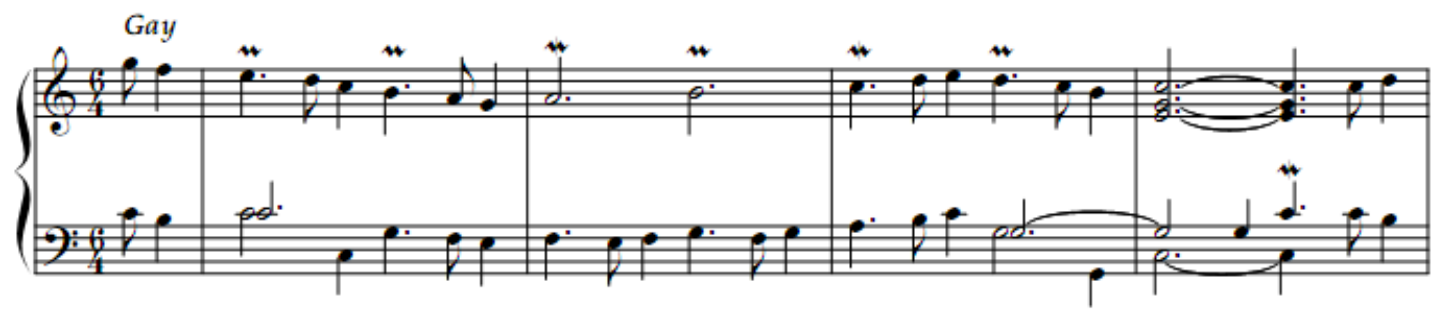

\footnotetext{
${ }^{135}$ Fuller.

136 IMSLP.

${ }^{137}$ IMSLP.
} 
The $18^{\text {th }}$ Century was also a period of intense activity for French composers of Pièces de Clavecin. Important collections were published by François (Charles) Dieupart (1670-1740), Clérambault, Jean-François Dandrieu (1682-1738), Le Roux, La Guerre, Marchand, and Rameau. These works represent a transition from the compositional style of the $17^{\text {th }}$-Century masters - Chambonnières, Louis Couperin, Lebègue, and d'Anglebert - to the styles and genres of the new century. ${ }^{138}$

\section{-Rameau-}

It will not be possible to discuss thoroughly the contributions of all of these composers in this project; however, in order to demonstrate this transition, I will focus on Rameau, who apart from François Couperin, wrote some of the most interesting and exciting French keyboard music of the early part of the $18^{\text {th }}$ Century. At first, Rameau takes a rather conservative approach to his keyboard compositional style; his first publication (1706, seven years prior to François Couperin's first book) contains a single suite consisting of nine movements:

- Prelude (unmeasured)

- Allemande I

- Allemande II

- Courante

- Sarabandes I and II

- Gigue

- Vénitienne

- Gavotte

- Menuet

${ }^{138}$ Silbiger, 127. 
The only new and original dance added is a vénitienne; while the entire suite is of very high compositional quality, Rameau basically follows the classic formula established by French masters of the past. ${ }^{139}$

However, in Rameau's next publication (1724, 18 years after the first) he demonstrates some clear changes in his approach to keyboard writing; two suites are included in this book - one in E and the other in D. François Couperin had already published his first three books by this time, and he undoubtedly influenced Rameau. The first suite begins like a classical suite but with the sarabande left out: "Allemande," "Courante," "Gigue en rondeau I," and "Gigue en rondeau II." Rameau then inserts two pieces that contain descriptive titles with programmatic associations, something that Couperin did many times in his first three publications. Perhaps the most fascinating of these pieces is "Les Rappel des Oiseaux," a work that imitates the singing of birds, followed by another descriptive piece entitled "La Villageoise (rondeau). ${ }^{, 140}$ Rameau then moves on to the second suite in $\mathrm{D}$, which consists of ten movements, all furnished with descriptive titles. Couperin's preface to his first book of harpsichord works (quoted below) obviously made a profound influence on Rameau.

Rameau's final book of harpsichord suites is entitled Nouvelles Suites de Pièces de Clavecin (1728). As was the case with the 1724 publication, two suites are included: one with seven movements in A, and one with eight movements in G. An additional similarity between Nouvelles Suites de Pièces de Clavecin and the 1724 publication lies in the structural make-up of each suite. The first suite begins with the classic A-C-S formula but later moves into new territory. The second suite, as was the case with the

\footnotetext{
${ }^{139}$ Marshall, R., Ed. Eighteenth-Century Keyboard Music. (New York: Schirmer, 1994), 141-142.

${ }^{140}$ Marshall, 142.
} 
second suite of the 1724 publication, almost entirely dispenses with the classical formula and relies on programmatic titles. A comparison between the 1724 and 1728 publications runs as follows:

Pièces de Clavecin (1724)

Suite in E Minor/Major

- Allemande

- Courante

- Gigue en rondeau I

- Gigue en rondeau II

- Le Rappel des Oiseaux

- La Villageoise (Rondeau)

- Rigaudons I and II

- Muzette en rondeau

- Tambourin

Suite in D Minor/Major

- Les Tendres Plaintes (Rondeau)

- Les Niais de Sologne and two Doubles

- Les Soupirs

- La Joyeuse (Rondeau)

- La Follette (Rondeau)

- L'Entretien des Muses

- La Boiteuse

- Les Tourbillons (Rondeau)

- Le Lardon (Menuet)

- Les Cyclopes (Rondeau)

Nouvelles Suites de Pièces de Clavecin (1728)

Suite in A Minor/Major

- Allemande

- Courante

- Sarabande

- Les Trois Mains

- Fanfarinette

- La Triomphante

- Gavotte and 6 Doubles 
Suite in G Major/Minor

- Les Tricotets (Rondeau)

- L'Indifférente

- Menuets I and II

- La Poule

- Les Triolets

- Les Sauvages

- L'Enharmonique

- L'Egyptienne

Despite the fact that Rameau outlived François Couperin by 31 years, he never again composed keyboard suites after 1728, two years prior to Couperin's final book and five years prior to Couperin's death. As a conclusion to our section on Rameau, I present a brief excerpt from Rameau's final piece from Nouvelles Suites de Pièces de Clavecin:

Example 5.8 Rameau: "L’Egyptienne” from Nouvelles Suites de Pièces de Clavecin. ${ }^{141}$

\section{L' Egyptienne}

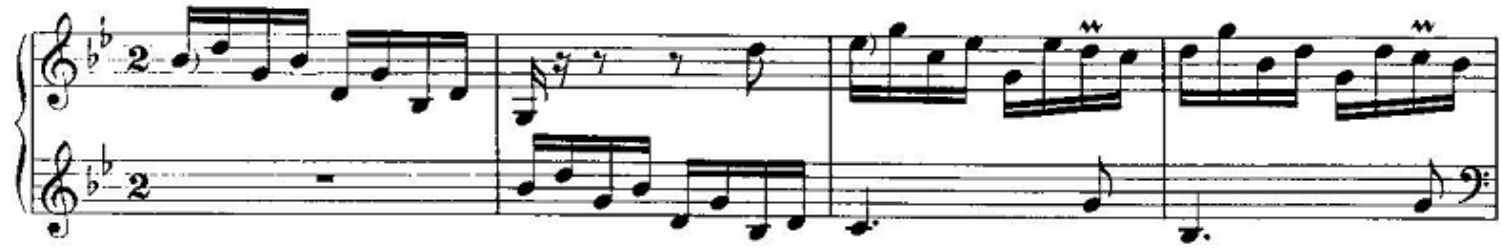

- François Couperin-

As stated in the introduction, the greatest and most significant contributor to the French keyboard suite in the $18^{\text {th }}$ Century was François Couperin, whose suites (referred to by the composer as ordres) present the highest level of original and creative writing in France during the first half of the $18^{\text {th }}$ Century. Couperin was among the first to abandon

${ }^{141}$ IMSLP. 
partially and at times completely the traditional dance names in his keyboard compositions, and he states in the preface to his first book of harpsichord works that "different occasions" supplied the ideas for the various pieces, as indicated in the titles:

I have always had a subject in mind when composing these pieces subjects suggested on different occasions. Thus the titles correspond to ideas I have had; I hope I may be excused from explaining them further. But since, among the titles, there are some which appear to indulge my own vanity, I should add that the pieces they describe are types of portraits which have sometimes been judged quite lifelike when I performed them, and that any flattery in the titles is intended for those memorable originals I wished to depict rather than for the copies I have made in these musical portraits. I have worked on this first book for over a year, sparing no expense or trouble; and to this careful attention are owed the fine quality and precision one will notice in the engraving. ${ }^{142}$

Couperin's four books provide a total of 27 ordres:

- Book I: 5 ordres, Nos. 1-5 (1713)

- Book II: 7 ordres, Nos. 6-12 (1716)

- Book III: 7 ordres, Nos. 13-19 (1722)

- Book IV: 8 ordres, Nos. 20-27 (1730)

Scholars, such as Marshall, suspect that the works for the first volume were actually composed and compiled over a number of years rather than in a little over one year as is stated by Couperin above; one must realize that Couperin was 45 years old when his first book was published in 1713. The number of movements in each ordre also varies greatly: 4 movements in Ordre No. 4 and 23 movements in Ordre No. $2 .{ }^{143}$ The average number of movements in each ordre is around 15 , and this also serves as proof that Couperin was still thinking in terms of suite compilations in which a performer

\footnotetext{
${ }^{142}$ Beaussant, P. François Couperin. Trans. by A. Land. (Portland: Amadeus Press, 1990), 221-222.

${ }^{143}$ Marshall, 138.
} 
would select several movements for a performance but did not intend to play them all straight through.

Book II demonstrates Couperin's compositional maturity as well as the overall change in French taste. The average number of pieces in each ordre has dropped to eight (a number far more manageable for performers at a single sitting) and only one ordre (No. 8) retains the classical "core" of dances. Some of Couperin's most famous harpsichord music is found in Book II and includes titles such as "Les Bergeries" and “Les Barricades Mistérieuses" (both from Ordre No. 6). ${ }^{144}$

Example 5.9 François Couperin: "Les Baricades Mistérieuses" from Ordre No. $6 .{ }^{145}$

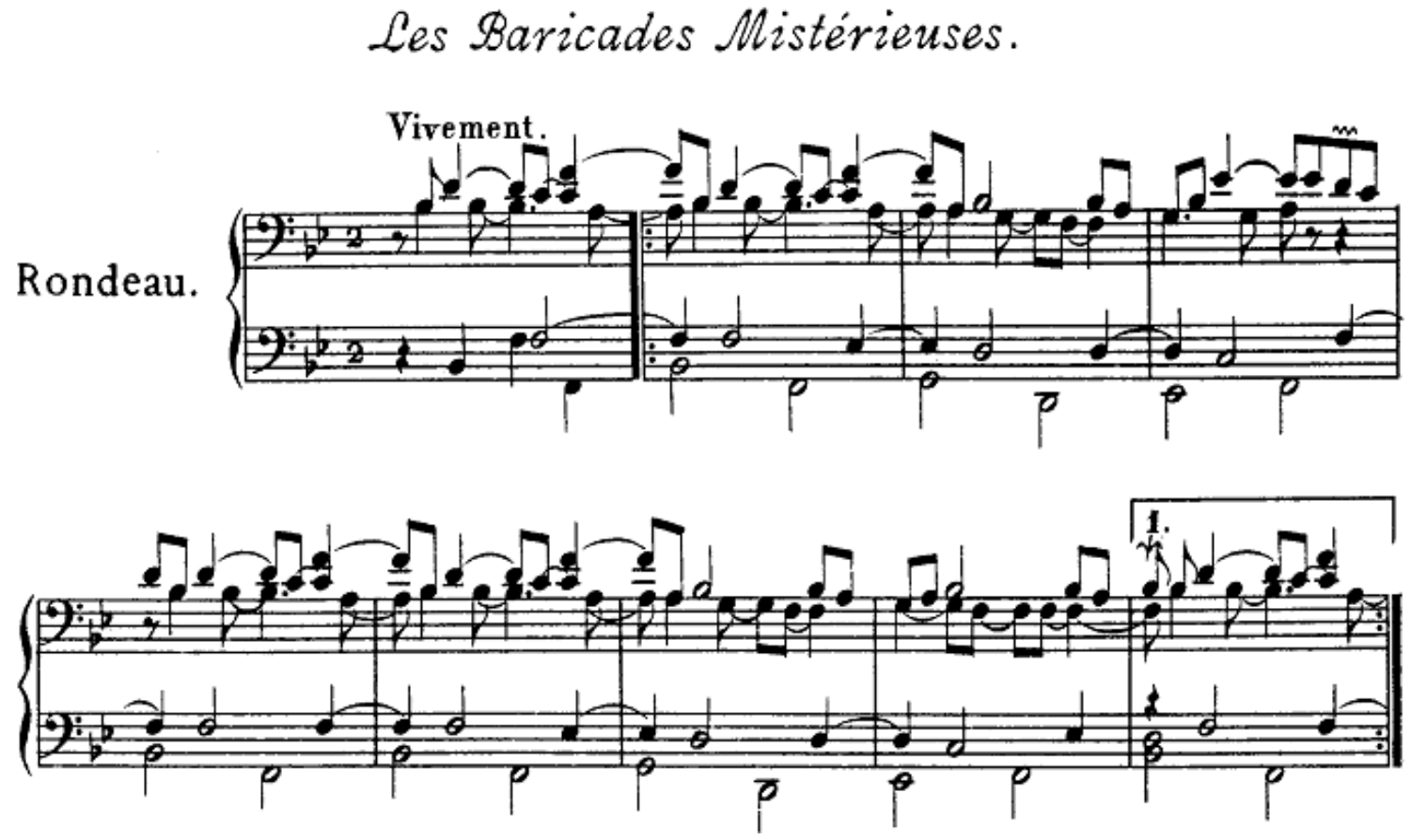

\footnotetext{
${ }^{144}$ Marshall, 139.

145 IMSLP.
} 
Marshall describes Book III best when he states that:

The level of artistry is maintained in Book Three (1722). In the eighteenth ordre alone one encounters harmonic language of power and pathos (Allemande La verneüil), elegant simplicity (Soeur Monique), vivid intensity (Le turbulent), the humor of the commedia dell'arte (Le galliard boiteux) and brilliant descriptive writing (Le tic-toc-choc. Ou Les Maillontins). ${ }^{146}$

Example 5.10 François Couperin: "Le Tic-Toc-Choc" from Ordre No. $18 .{ }^{147}$

$$
\text { Le Iic-Joc-Choc, ou les Maillotins. }
$$

Piéce croisée.
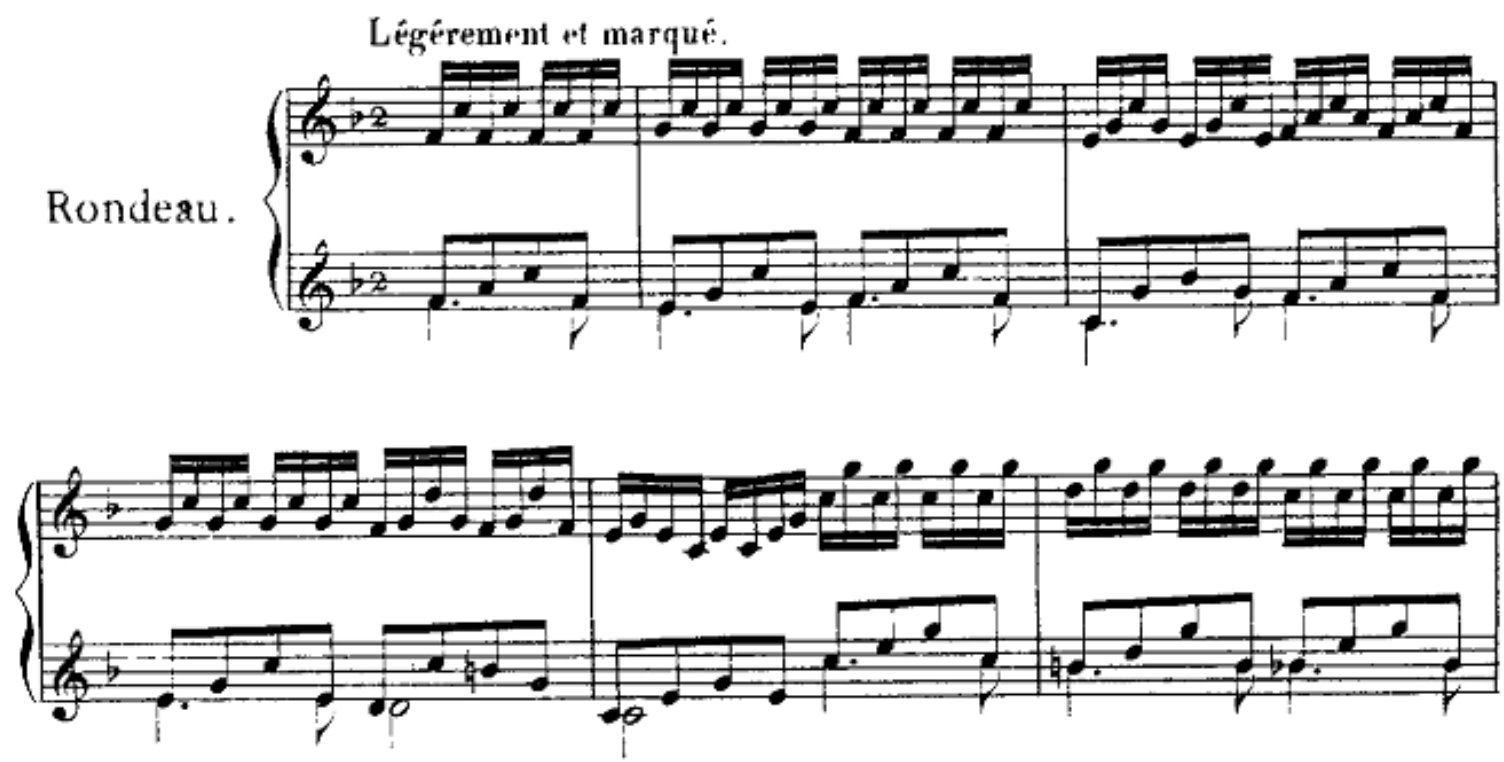

Book IV (1730) is made up of pieces that Couperin claims to have written about three years prior to their publication. By this time, three years before his death, Couperin was a very sick man, and a number of the pieces in this book reflect a solemn and grave

\footnotetext{
${ }^{146}$ Marshall, 139.

${ }^{147}$ IMSLP.
} 
character that depict the characteristics of an artist coming to the end of his creative career. Some of the titles for these pieces include: "Les Ombres Errantes," "La Convalescente," "L’Epineuse," and "La Mistériuse.",148

Example 5.11 François Couperin: "Les Ombres Errantes" from Ordre No.25. Notice Couperin's use of the term, "Languissamment," to describe how the piece should be played. $^{149}$

\section{Les ombres errantes.}
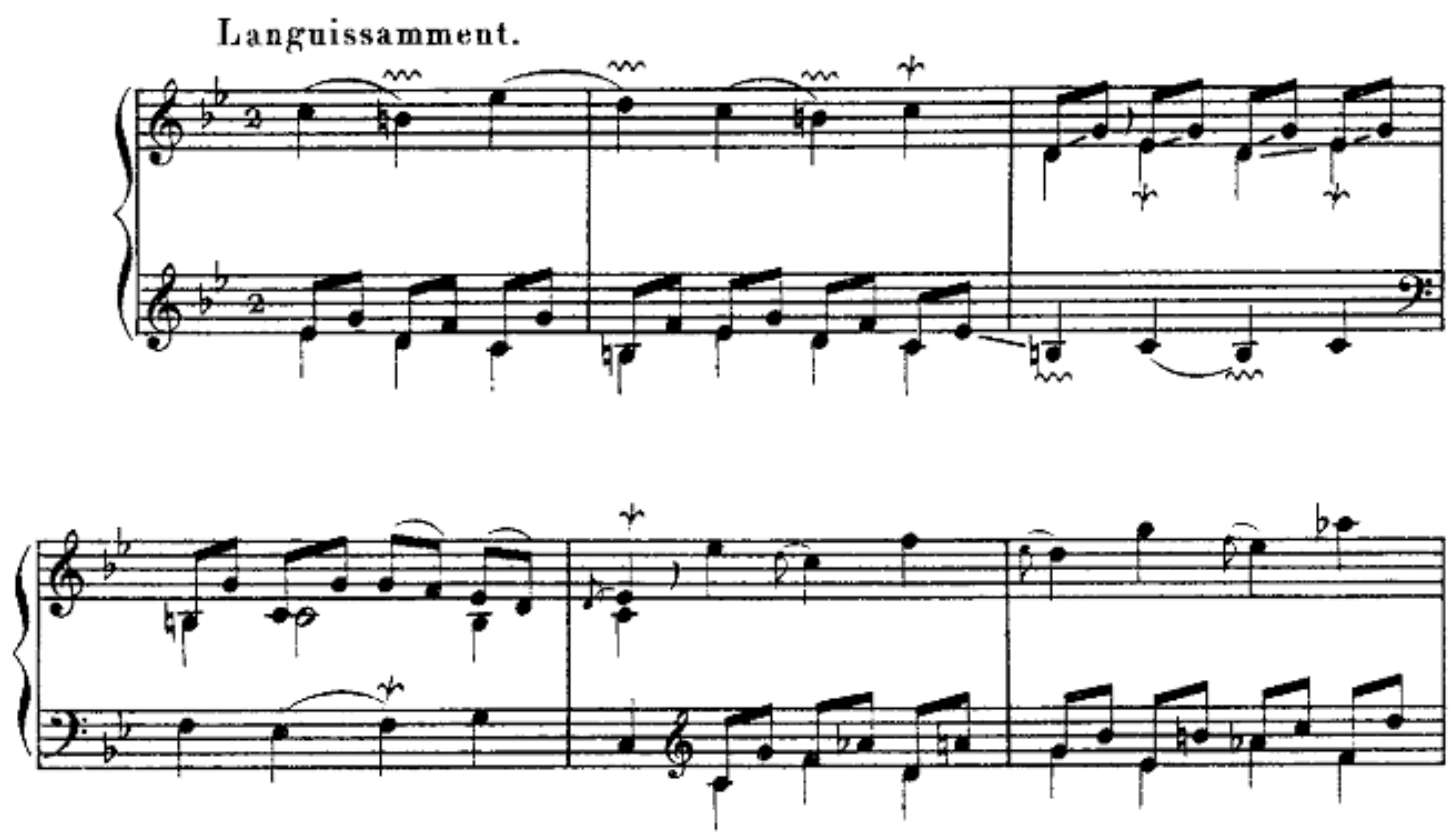

Couperin also wrote works that may be referred to as free ordres. These are sets of programmatic pieces within a suite: ("Les Petits Âges," Ordre No. 7), ("Les fastes de la grande et anciénne Mxnxstrxndxsx," Ordre No. 11), ("Les folies françoises," Ordre No. 13), and a group of bird pieces (Ordre No. 14). In addition, there are several

${ }^{148}$ Beaussant, 316-317.
${ }^{149}$ IMSLP. 
programmatically linked pairs or groups of three. These free ordres are original, personal, and difficult to explain: "the taste is there, but the recipes have been thrown away."

Some of the free programmatic ordres even come with amusing stories: In "Les fastes de la grande et anciénne Mxnxstrxndxsx," we see a not-so-subtle attempt by Couperin to poke fun at "The Order of Fiddlers" a long-standing musician's guild in Paris founded in 1321 and known as the Grand and Ancient Ménestrandise. Replacing the vowels with x's was a joking effort by Couperin to hide his intentions, while it was in reality quite obvious who he was making fun of. ${ }^{151}$

During Couperin's lifetime there were quarrels regarding the question of whether or not organists and keyboardists should be forced to join the guild and pay dues. Couperin and his keyboard colleagues felt that they did not need a guild and would not derive any benefit from it. Of course, the Order of Fiddlers felt differently but had enough problems of its own: In fact, after many difficulties that had begun well before Couperin's birth, its existence ceased in the generation following his death. ${ }^{152}$

Another example of Couperin's unique approach to free ordres may be found in Les Petits Âges. Couperin scholar Beaussant put it best when he said, "Here is a picture in four parts, in which the sections are linked only by the composer's intent and the atmosphere of sweetness and charm which permeates the Septiême Ordre." ${ }^{, 153}$ In other words, we are not looking at a programmatic story, but a brief collection of charming and highly ornamented musical "pictures." This is a fine example of the typical French approach to composition in the Baroque Era.

\footnotetext{
${ }^{150}$ Fuller.

${ }^{151}$ Beaussant, 66.

${ }^{152}$ Beaussant, 66-67.

${ }^{153}$ Beaussant, 263.
} 
Example 5.12 François Couperin: "La Muse Naissante" from Les Petits Âges. ${ }^{154}$
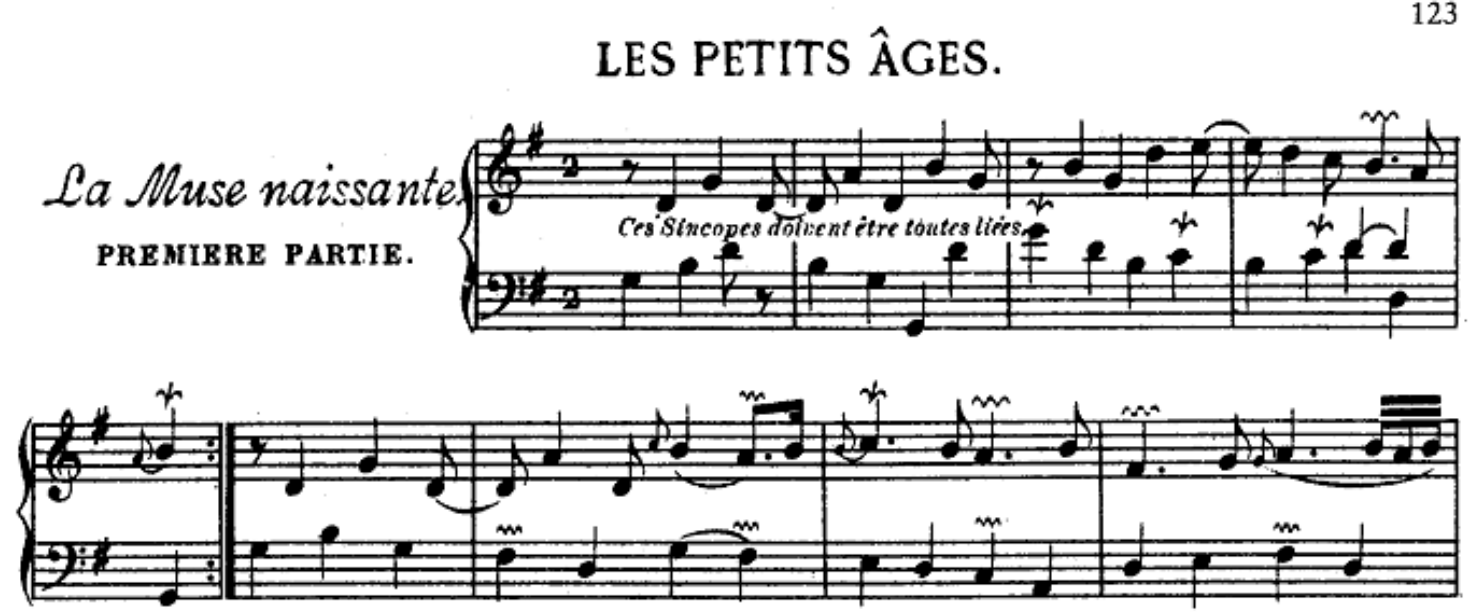

Example 5.13 François Couperin: "L’Enfantine."155

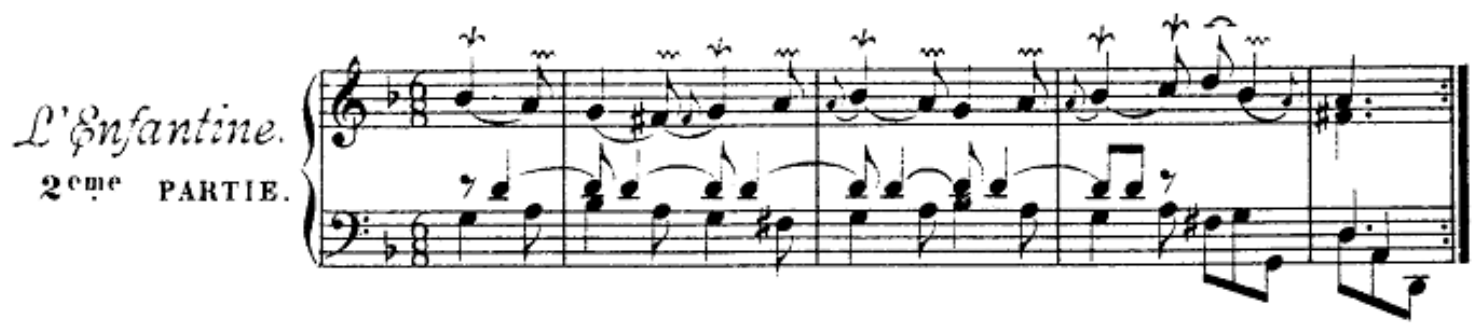

Example 5.14 François Couperin: "L’Adolescente."156

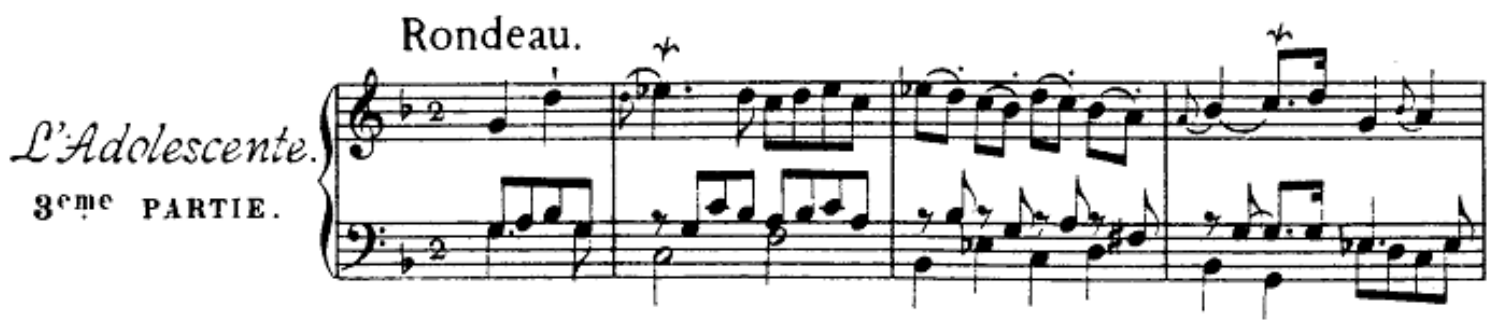

\footnotetext{
${ }^{154}$ IMSLP.

${ }^{155}$ IMSLP.

${ }^{156}$ IMSLP.
} 
Example 5.15 François Couperin: "Les Délices.","157

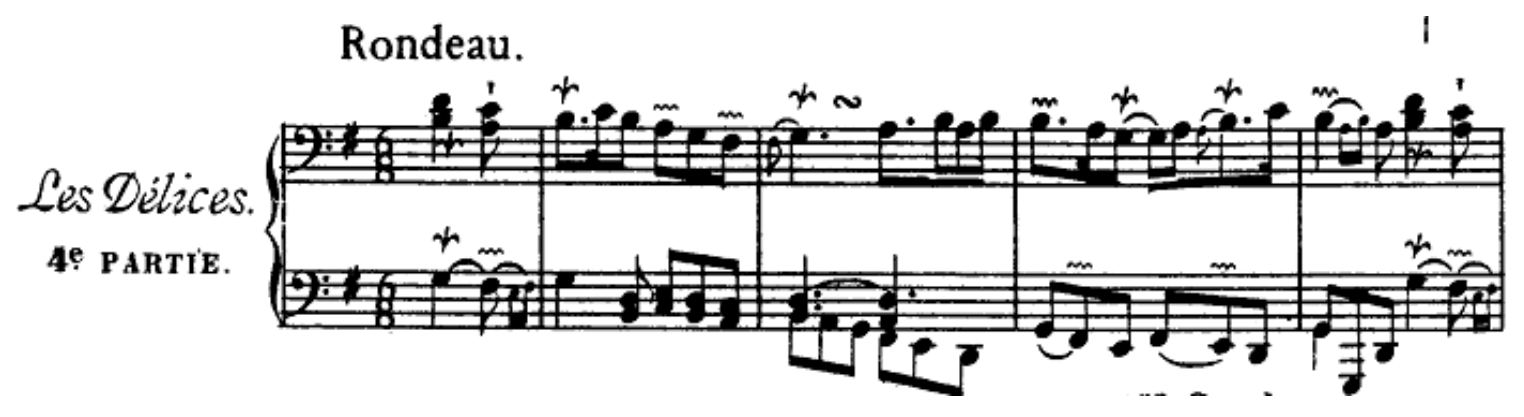

While other French composers, such as Dieupart, made contributions to the French keyboard suite following François Couperin, it is perhaps best to end our discussion here. As we can see, the French played a crucial role in the early development of the keyboard suite and continued in its propagation well into the $18^{\text {th }}$ Century. French composers also profoundly influenced compositional practices in other European nations (particularly England and Germany), thus contributing to a multicultural development of the suite conception throughout Europe. My next task shall be to investigate this genre as it developed in England.

${ }^{157}$ IMSLP. 


\section{Chapter VI}

\section{The English Keyboard Suite}

England presents a difficult task in terms of keyboard suite development. The first stumbling block we face lies in the fact that very little is known about the evolution of English keyboard music from the 1620 s to the middle of the $17^{\text {th }}$ Century, the decades following the deaths of the great virginalists William Byrd (1540-1623), John Bull (15621628), and Peter Philips (1560-1633), among others. Only around 1650 does the picture become clearer, with the compositions of Benjamin Rogers (1614-1698), Christopher Gibbons (1615-1676), and Locke. ${ }^{158}$

The second stumbling block lies in the fact that England's greatest and most imaginative Baroque composer, Purcell, died in 1695 (at 35 years of age). While England still had composers of talent, there were also many foreign composers who took advantage of England's temporary lack of native genius. These composers included an Italian, Giovanni Battista Draghi (1640-1708), and a German, Handel. I have chosen to discuss Draghi in this chapter but have decided to save Handel's keyboard contributions for the chapter on Germany; despite the fact that Handel lived in London for the last 47 years of his life, much of his keyboard music was written prior to his departure from Germany, including early versions of the works he eventually published while in England.

Essentially, there was no single towering figure of keyboard suite composition in England as there was with François Couperin in France and Bach in Germany. Locke and

${ }^{158}$ Apel, W. The History of Keyboard Music to 1700. Trans. H. Tischler. (Bloomington: Indiana University Press, 1972), 748-750. 
Purcell made the most significant contributions to the development of the genre in England, but their output of keyboard suites was unfortunately very limited. However, there were still important published collections and developments that took place in England during the Baroque, particularly in the latter half of the $17^{\text {th }}$ Century. My discussion for this chapter will therefore commence with a look at printed collections of keyboard music that circulated throughout England and then move on to Locke and Purcell. I shall then discuss briefly the compositions of other lesser-known composers who also wrote keyboard suites but did not necessarily contribute much to the genre's development in England.

\section{-Musick's Hand-maide and Melothesia-}

Various dances, such as allemandes and courantes, were being composed in England in the first half of the $17^{\text {th }}$ Century, but the first serious attempt at grouping dances into suites was made in a publication by John Playford (1623-1686) entitled Musick's Hand-maide Presenting New and Pleasant Lessons for the Virginals or Harpsycon (1663). ${ }^{159}$

Two of the composers represented in this collection are William Lawes (16021645) and Benjamin Rogers, among others. Nearly 80 pieces are to be found in Musick's Hand-maide, and almost all are in binary form, with a single melody line in the right hand and spare, two-voice harmonic accompaniment in the left. Varied repeats are left out, and the overriding characteristic of this publication is one of extreme simplicity. ${ }^{160}$

\footnotetext{
${ }^{159}$ Silbiger, A. Ed. Keyboard Music Before 1700. (New York: Routledge, 2004), 67.

${ }^{160}$ Silbiger, 67.
} 
However, one is forced to question the notion that early English composers of keyboard suites were simple-minded in their approach to their craft. They may not have had a choice in the matter. For example, let us look at an excerpt from Playford's introduction to Musick's Hand-maide:

... the Virginals; an instrument of much delight and variety of harmony, as being the same with the Harpsycon and Organ; which excellency hath made it the delight of many young ladies and gentlewomen, whose accommodation induced me to select these new and pleasant lessons, which are not only easy but delightful for young practitioners, being most of them late tunes and dances set to the virginals after the newest mode, and are so composed that the treble violin may play the tunes along with the virginals, which will be a pleasant consort. ${ }^{161}$

One has to wonder if Playford may have altered the original compositions in order to suit his purposes.

The second major published collection of keyboard music in England to contain suites was Melothesia ("Setting of the Melody"), which dates from 1673. This book, according to its title page, was "All carefully reviewed by M. Locke, Composer in Ordinary to His Majesty, and Organist of Her Majesties Chappel.” Melothesia contains 61 pieces for keyboard, most of which were written by Locke. Additionally, several of his lesser-known contemporaries are also represented, such as William Gregory (16241691) and John Banister (1630-1679). ${ }^{162}$

The suites in Melothesia typically consist of four to five movements grouped by key, and they more or less follow the $17^{\text {th }}$-Century classical "core" (A-C-S) established on the continent. A prelude was sometimes added to the beginning of a suite, and an additional dance of "English" character was oftentimes added to the end; examples

\footnotetext{
${ }^{161}$ Silbiger, 68.

162 Apel, 748-750.
} 
include "Country Dance," "Roundo," “Jig,” or "Horne Pipe.” The structure of Locke's five-movement Suite in $C$ from Melothesia runs as follows:

Suite in $C$

- Prelude

- Almain

- Corant

- Saraband

- $\mathrm{Jig}^{163}$

-Locke-

Melothesia contains the majority of Locke's output for keyboard as well as four of his five suites. Through these compositions, Locke established a norm for the suite genre in England. However, as we move our discussion in the direction of Locke's own compositional efforts, it is imperative that we look into the influences that brought the genre to England and that may have played a role in his conception of the suite.

Ironically, Locke claimed to have little admiration for the works of foreign composers; nonetheless, the structure and style of his keyboard suites, such as the Suite in $C$ shown above, tell us a different story: The "Prelude" from this suite is notated but sounds very much like an "unmeasured" French prelude, which may betray the influence of the French lutenists who arrived with Charles II (1630-1685) upon his return to England for the Restoration. ${ }^{164}$ This prelude is perhaps Locke's most fascinating keyboard composition, as it demands to be played slowly and freely and wanders through numerous arpeggiated strains that briefly touch on several different keys before coming to a close. While the entire score cannot be reproduced here, a short description by Silbiger allows us to understand the novelty of this prelude:

${ }^{163}$ Borren, C. The Sources of Keyboard Music in England. Trans. by J. Matthew. (Westport: Greenwood, 1970), 53.

${ }^{164}$ Caldwell, J. English Keyboard Music Before the Nineteenth Century. (New York: Dover 1986). 110. 
... Measures 4-6 hint at D minor, C major, F major, D minor, A minor; in strain II, mm. 11-15 move through D minor, A minor, F major, G major, $F$ major, D minor, G minor, G major. This constant touching upon different keys produces a rather unsettled feeling in the listener. The wayward effect is reinforced by the fact that there is hardly any reuse of melodic or rhythmic motives in the piece ... ${ }^{165}$

A second argument for an outside influence upon Locke and keyboard suite writing throughout England is the presence of Froberger in London in 1662. As I shall discuss in the following chapter, Froberger had a powerful musical personality and played an important role in the codification of the keyboard suite as a multi-movement work consisting of A-C-S-G. It is hard to believe that the two would not have met during the older composer's stay. ${ }^{166}$

\section{-Purcell-}

My attention now moves to Purcell, the most famous English composer of the $17^{\text {th }}$ Century and a pupil of Blow, whose own music I shall discuss later. It is important to remember that while Purcell was a student of Blow, his teacher outlived him by 13 years and published his contributions to the suite literature only after Purcell's death. Purcell's keyboard works are not nearly as numerous as his ecclesiastic and secular vocal works (anthems, odes, dramatic music, operas) or his chamber music, but they do include pieces of historical interest and artistic importance. ${ }^{167}$

Eight suites by Purcell were printed in 1696, the year after his death, in A Choice Collection of Lessons for the Harpsichord or Spinnet Composed by the late Mr. Henry Purcell Organist of his Majesties Chappel Royal, \& of St. Peters Westminster

\footnotetext{
${ }^{165}$ Silbiger, 70-71.

${ }^{166}$ Somer, A. "The Keyboard Music of Johann Jakob Froberger." (PhD diss., University of Michigan, 1962).

${ }^{167}$ Apel, 760 .
} 
[Westminster Abbey]. This collection was published by Purcell's widow, Frances, and the exact ordering and constitution of movements within the suites may not in every case have been Purcell's own; Suite No. 3 in G major (Z. 662), for example, appears incomplete as it contains only prelude-A-C. Additionally, the final movements of the last two suites are arrangements of music from Purcell's stage works. ${ }^{168}$ Were these Purcell's own arrangements, or did Frances hire another composer to finish the suites?

Each suite consists of four movements with the exceptions of No. 3 in G major (three movements), No. 6 in D major (Z. 667) (three movements), and No. 7 in D minor (Z. 668) (three movements); except for Nos. 1 (Z. 660) and 3, both in G, each of Purcell's suites is in a different key. Structurally, the suites loosely follow the A-C-S formula, as was the case with Locke's works, and each is preceded by a prelude.

Purcell did not use as many non-core dance types as Locke did. As a matter of fact, Purcell only employed two different dances outside the classical "core" in his suites - the minuet and the hornpipe - and in all of these cases he used them at the end of the suite as a replacement for a sarabande or gigue. At no point did the composer actually "incorporate" other dances between the core dances. In this sense, Purcell actually stayed closer to the more rigid German construction of the keyboard suite that I shall discuss in detail in the following chapter. Once again, although there is a lack of strong documentary evidence regarding Froberger's activities in London during his 1662 trip (or even how long he stayed in England), I am compelled to suggest that his influence on English harpsichord composers was profound and long lasting.

\footnotetext{
${ }^{168}$ Silbiger, 75.
} 
-Blow, Draghi, and Jeremiah Clarke (1673/4-1707)-

Another major figure in English keyboard music in the second half of the $17^{\text {th }}$

Century was Blow. In fact, Blow is widely considered to be one of the three great

Restoration keyboard composers, on equal footing with Locke and Purcell. He wrote and published more music for harpsichord and organ than either of his colleagues; however, of the six keyboard suites that can be found in his oeuvre, none of them displays the level of quality established by Locke and Purcell in their suites. By way of information, Blow's first publication, A Choice Collection of Lessons for the Harpsichord, Spinnet \&c... By Dr. John Blow (1698) contains four "Sett's," and two further publications include one suite each: A Choice Collection of Ayres by various composers and The Second Part of Musick's Hand-maid (1689) (This was the second edition of Playford's original publication from 1663). ${ }^{169}$

A composer of lesser stature, Draghi, was an Italian who flourished in London from 1667 to 1706. Around 1700 he published Six Select Suites of Lessons for the Harpsichord, in which preludes are combined with the four traditional dances and other pieces in several ways. For example:

Suite No. 1 in E minor

- Prelude

- Allemande

- Courante

- The Complaint Aire

- Gigue

${ }^{169}$ Silbiger, 78. 
Suite No. 2 in G major

- Prelude

- Allemande

- Courante

- Sarabande

- Aire: The Hunting Tune

Suite No. 5 in D minor

- Prelude

- Allemande

- Courante

- Sarabande

- Bore Aire

- Minuet $^{170}$

Clarke, like Purcell, was a pupil of Blow. During his lifetime a few keyboard pieces were printed in the collections A Choice Collection of Ayres for the Harpsichord (Young, 1700) and The Harpsichord Master (Walsh, 1700), and six of his suites are included in the posthumous volume Choice Lessons for the Harpsichord or Spinett, Mr. Jeremia Clarke (1711). ${ }^{171}$ As is the case with Purcell, Clarke is an example of a very talented composer who did not place much emphasis on keyboard writing. Performing editions for Clarke's suites are not available at this time and making a quality assessment of his keyboard music is difficult at best.

While a few other English composers wrote keyboard suites in Baroque-Era England, I feel that the above-mentioned composers made the most significant contributions and helped England to develop a national artistic identity through their own personal conceptions of the suite in combination with the French and German influences that came to their country. However, one of the greatest difficulties in assessing Baroque

${ }^{170}$ Apel, 752-753.
${ }^{171}$ Apel, 763-764. 
English music lies in the fact that England's greatest composer of the time was not an Englishman: While Handel lived in London for the last 47 years of his life, he was still German by birth, and his keyboard suites, though not numerous, were among the strongest keyboard works being published at the time. In the next chapter I shall move our discussion to Germany and look at the contributions of Handel, Bach, and other Germans, who brought the keyboard suite genre to an incomparable level of development and perfection. 


\section{Chapter VII}

\section{The German Keyboard Suite}

The situation for a discussion of the development of the keyboard suite in Baroque Germany is almost the opposite from that encountered for England: There are almost too many composers of quality who wrote keyboard suites and made noteworthy contributions! Nearly every German composer of merit left behind a body of works for organ and/or harpsichord, and the suite genre for keyboard was one of the most common types of composition used. In that regard, I have compiled a partial list of German composers who wrote keyboard suites:

1. Bach

2. Böhm

3. Buxtehude

4. Johann Heinrich Buttstett (1666-1727)

5. Fischer

6. Christian Flor (1626-1697)

7. Froberger

8. Johann Joseph Fux (1660-1741)

9. Handel

10. Johann Erasmus Kindermann (1616-1665)

11. Johann Krieger (1651-1735)

12. Kuhnau

13. Vincent Lübeck (1654-1740)

14. Franz Xaver Murschhauser (1663-1739)

15. Pachelbel

16. Alessandro Poglietti (?-1683)

17. Reincken

18. Ferdinand Tobias Richter (1649-1711)

19. Christian Ritter (1645-1725)

20. Benedict Schultheiss (1653-1693)

21. Franz Mathias Techelmann (1649-1714)

22. Telemann

23. Matthias Weckmann (1619-1674)

24. Christian Friedrich Witte (1660-1716)

25. Friedrich Wilhelm Zachow (1663-1712) 
This overabundance of composers presents us with the problem of sorting out the most important contributions and following them through to the conclusion of the Baroque Era in Germany.

For this chapter, I am going to use a plan that involves beginning with Froberger and concluding with Bach. Froberger was the first to make truly significant strides in the development of the German keyboard suite, and in many ways Bach was the composer who brought all that came before him to perfection and completion. My discussion shall therefore take a form that focuses on individual composers one at a time from beginning to end. Within the limited scope of this paper, composers whose contributions were of lesser importance will have to be left out.

For organizational purposes, our timeline of composers will appear as follows:

1. Froberger

2. Reincken

3. Fischer

4. Böhm

5. Kuhnau

6. Handel

7. Bach

-Froberger-

German clavier music in the mid- $17^{\text {th }}$ Century was dominated by the figure of Froberger, and his keyboard suites are a particularly important part of his compositional output. Some of his suites are among the earliest examples of a special type of suite to which the future belonged, in which A-C-S-G were treated as a fixed unit (although this was not always Froberger's preferred order). Despite the fact that the same dance types were already present in the works of Froberger's older French contemporary, 
Chambonnières, they were never treated as a performing unit, but only as parts of a large group of pieces in the same key. ${ }^{172}$

Example 7.1 A page from the manuscript presented by Froberger to Ferdinand III (16081657) (Froberger's patron). Notice the level of detail and care that went into preparing the manuscript. ${ }^{173}$

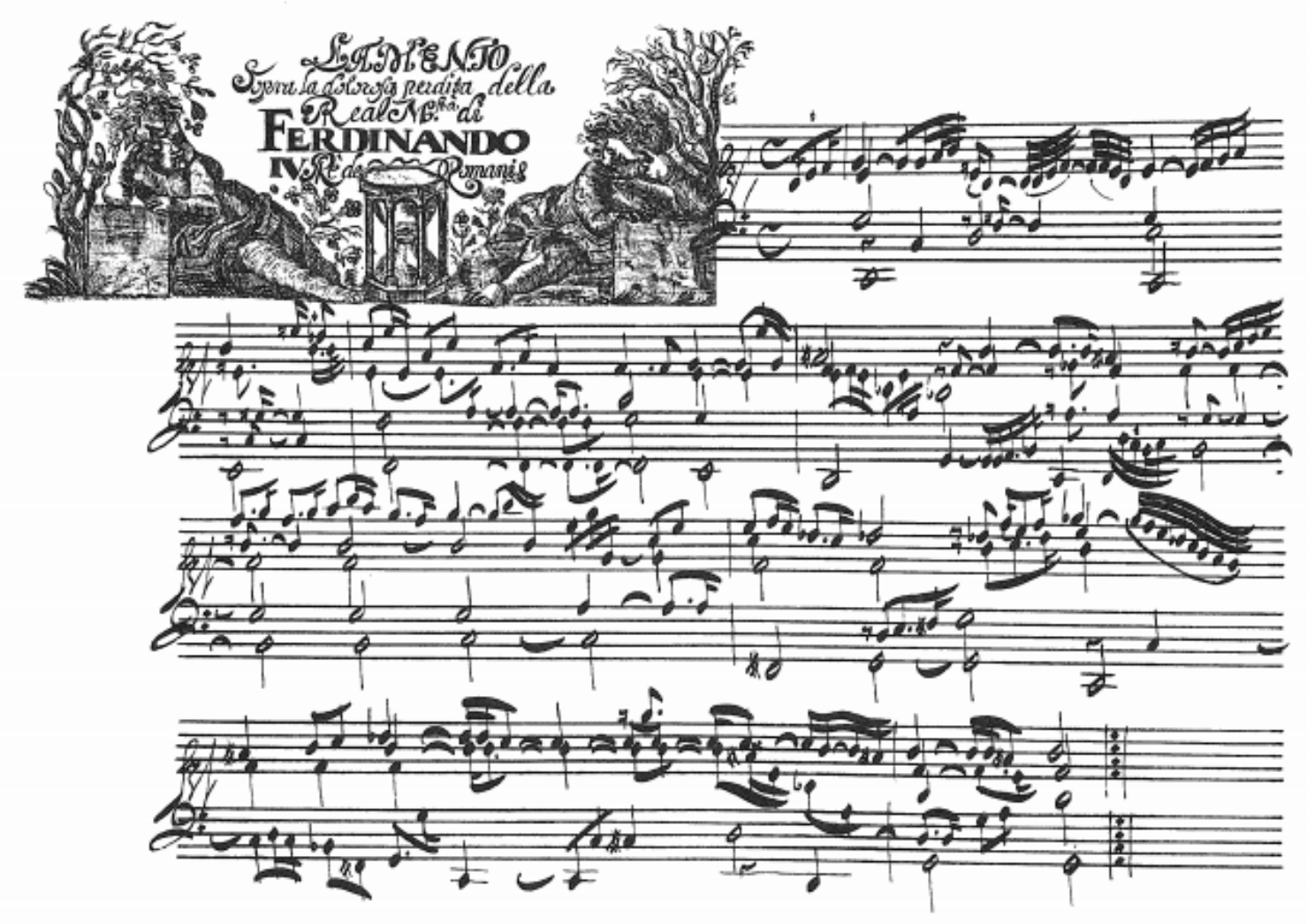

Whether or not Froberger can be regarded as the sole creator of the "classical"

keyboard suite as a fixed form, he was certainly among its earliest pioneers. Interestingly enough, the six suites contained in his 1649 autograph volume (shown above) were not originally labelled as suites; each dance in the sequence is headed by its own title without

\footnotetext{
${ }^{172}$ Apel, W. The History of Keyboard Music to 1700. Trans. H. Tischler. (Bloomington: Indiana University Press, 1972), 555.

${ }^{173}$ IMSLP [International Music Score Library Project]/ Petrucci Music Library. (Accessed 4/3/09) http://imslp.org/wiki/Main_Page.
} 
any collective title. Three of the suites from this volume (No. 1 in A minor, No. 3 in G major, and No. 5 in C major) consist of an allemande, courante, and sarabande. Suite No. 2 in D minor adds a gigue and places it at the end (Froberger's first example of A-C-SG). No. 6, called Partita auff die Maÿerin, is a type of variation suite based on a German folktune thought to have been a favorite of Ferdinand III; its six variations are followed by a courante, its double, and a sarabande.

Example 7.2 Froberger: "Gigue" appended to the end of Suite No. 2. It is interesting to note that Froberger's first known incorporation of a gigue into a suite places it at the end. His later suites have the gigue between the allemande and the courante. ${ }^{174}$

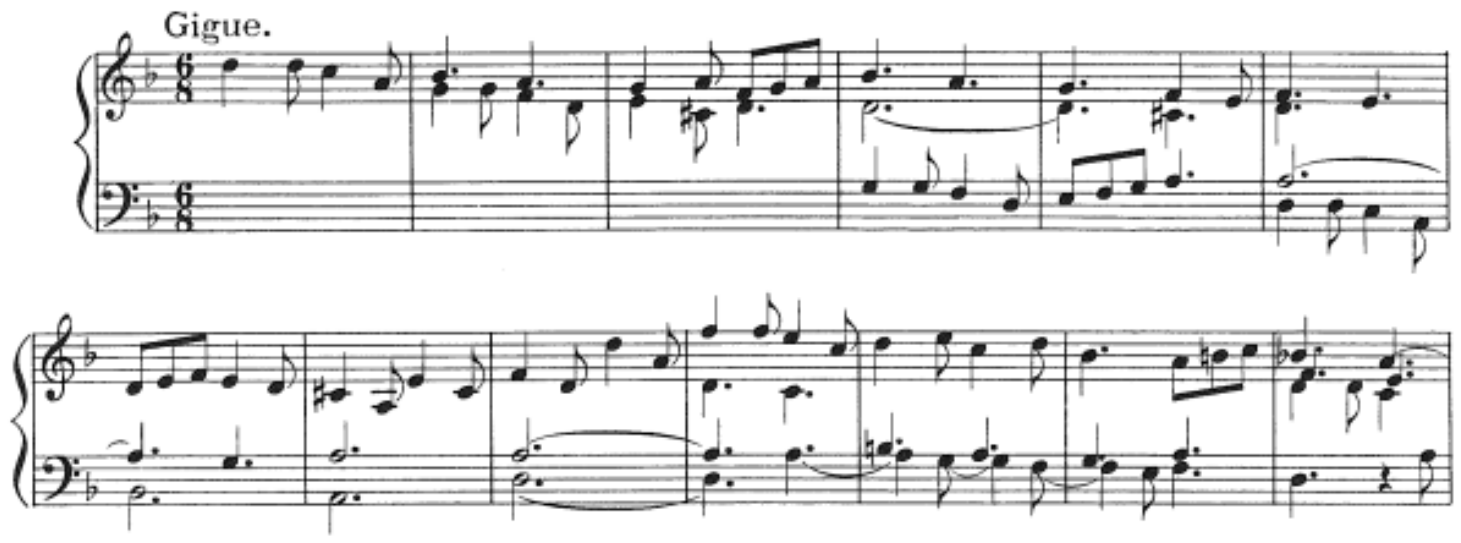

Another autograph volume (1657), also dedicated to Ferdinand III, contains

Suites Nos. 7-12, all of which include a gigue, which is inserted as the second movement, i.e., A-G-C-S. ${ }^{175}$ This sequence was Froberger's preference, according to his friend Weckmann. ${ }^{176}$ Nevertheless, a posthumous print by the Amsterdam publisher, Mortier, appeared in the 1690s presenting them as A-C-S-G, an order that became standard after

\footnotetext{
${ }^{174}$ IMSLP.

${ }^{175}$ Apel, 555-556.

${ }^{176}$ Schott, H. "Froberger," The New Grove Dictionary of Music and Musicians. Ed. by L. Macy. (Accessed 1/7/10) http://www.newgrovemusic.com.
} 
Froberger's death; however, the note "mis en meilleur ordre [placed in better order]" on the title page also proves that this arrangement did not originate with Froberger. ${ }^{177}$

There are another 18 authenticated suites composed by Froberger that were not included in the 1649 and 1657 autograph manuscripts mentioned above and were probably earlier compositions. Structurally, they fall into two principal groups: 13 are four-movement works, ten with the sarabande at the end and three with the gigue last; the other five are three-movement suites consisting of allemande, courante, and sarabande, each with a double. ${ }^{178}$ Additionally, in these earlier suites there is sometimes a thematic connection between the allemande and the courante:

Example 7.3 Froberger: "Allemande" and "Courante" from Suite No. 22 in E minor. ${ }^{179}$
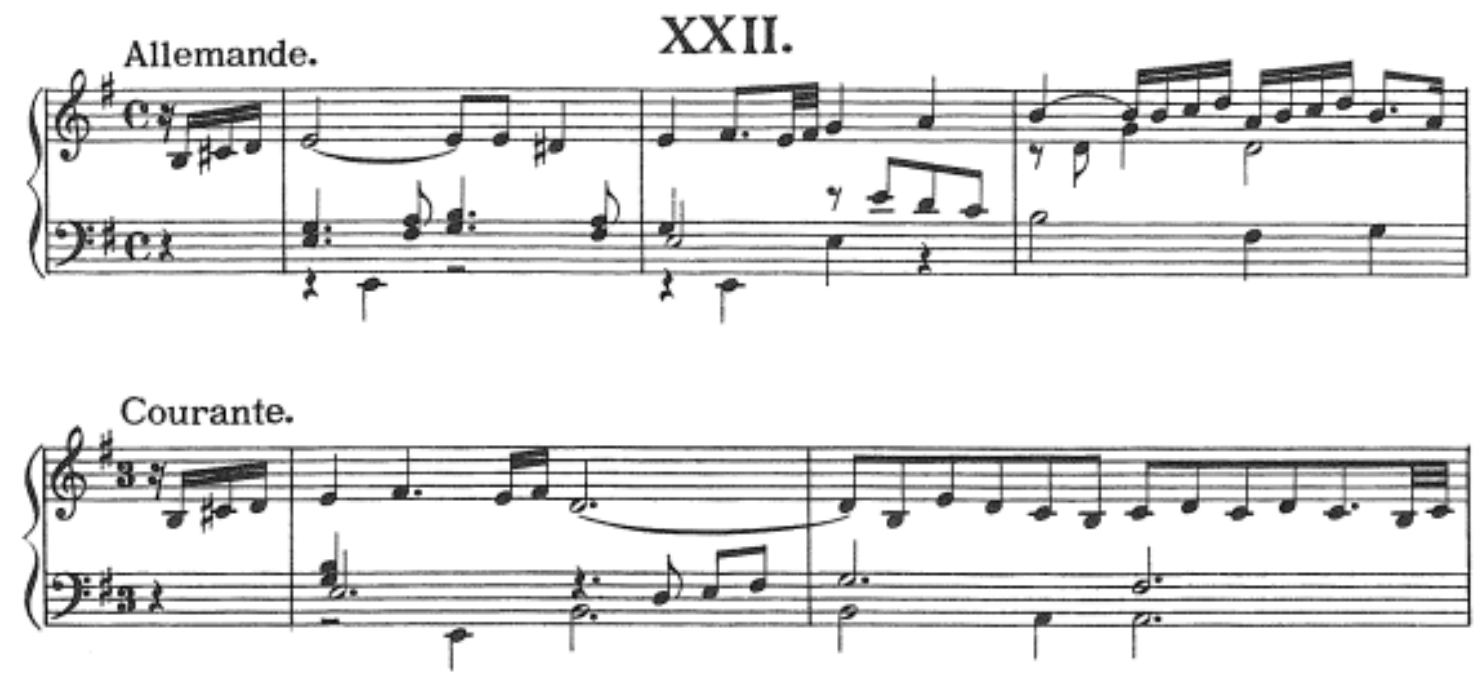

\footnotetext{
${ }^{177}$ Leonhart, G. “Johann Jakob Froberger and His Music.” L’Organo 6, (1968).

${ }^{178}$ Apel, 555-560.

${ }^{179}$ IMSLP.
} 
Schott, a Froberger specialist, best describes the suites when he states:

From a stylistic perspective, it is a loose-textured monophony enlivened by French lutenists' style brisé, that prevails in Froberger's suites. Contrapuntal part-writing is lightly reinforced by occasional thematic imitation, and the binary-form sections of the dances are repeated. The allemandes in particular show French influence, making significant use of style brisé, lute figurations that lend rhythmic freedom. However, they are more intensely expressive than the somewhat predictable allemandes of Chambonnières and the lutenists. ${ }^{180}$

Example 7.4 Froberger: "Allemande" from Suite No. 16 in G major. Note the scales, arpeggios, and general air of rhythmic freedom that prevails in the first half of this allemande. Also notice the clear harmonic motion from tonic to dominant in the A section, followed by a B section that opens in the dominant as well. ${ }^{181}$

46
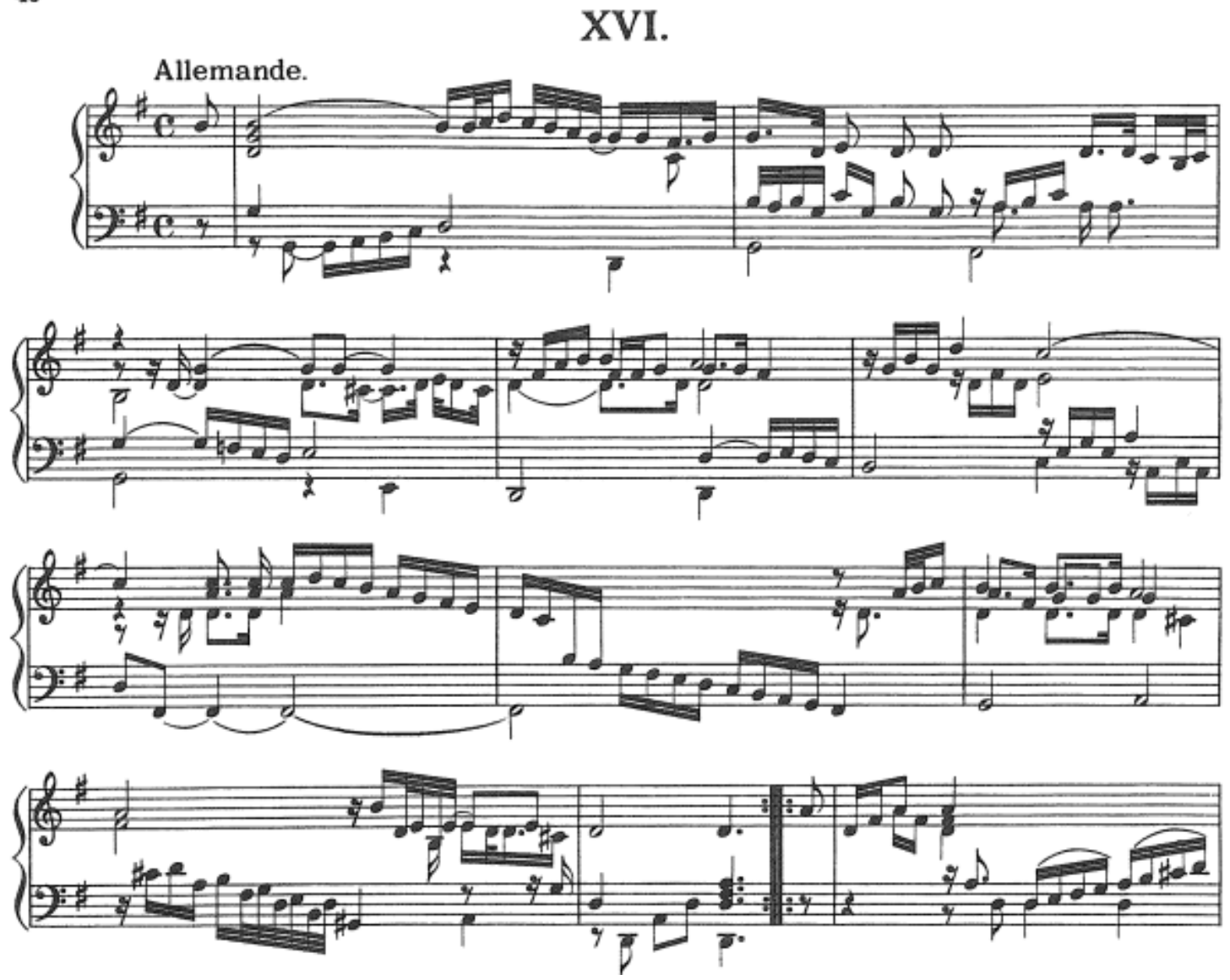

${ }^{180}$ Schott.

${ }^{181}$ IMSLP. 


\section{-Reincken-}

Reincken produced eight keyboard suites that follow a rigid A-C-S-G sequence throughout. He may have been the first to use exclusively this "classical" ordering in his keyboard suites, and in this sense played an important role (in addition to Froberger) in gaining acceptance for this ordering as the norm.

It would also appear likely that Froberger was a significant influence on Reincken not only in terms of structure, but also in terms of style; style brisé is a prominent characteristic throughout Reincken's suites, and his sarabandes in particular consist mostly of broken chords. His strongest movements are usually the gigues, which are typically on a larger scale than Froberger's. ${ }^{182}$ Later in life, Reincken also enjoyed the status and respect given to him by his younger colleagues who looked up to and deeply admired the near-centenarian: One of those admirers just happened to be Bach, who met and played for Reincken shortly before the older composer's death. ${ }^{183}$

\section{-Fischer-}

Another major figure in the development of the German keyboard suite is Fischer, who in addition to Kuhnau is generally credited with bringing Lully's highly influential style of composition to Germany. ${ }^{184}$ Fischer has four major published keyboard collections:

1. Les Pièces de Clavecin ... Oeuvre II (1696); second edition, entitled Musicalisches Blumen-Büschlein (1699)

2. Ariadne musica (1702)

3. Blumen-Strauss (1732)

\footnotetext{
182 Silbiger, 195.

${ }^{183}$ Wolff, C. Johann Sebastian Bach: The Learned Musician. (New York: W. W. Norton \& Company, 2000), 212-213.

184 Silbiger, 204.
} 


\section{Musikalischer Parnassus (1738)}

The two collections that contain keyboard suites and that, therefore, concern us in this project are Musicalisches Blumen-Büschlein and Musikalischer Parnassus.

The Musicalisches Blumen-Büschlein is essentially a collection of eight suites ("Partheyen" - a new title for the suite, similar to Kuhnau's "Partien" discussed below) that immediately takes German keyboard music in a new direction; although the traditional A-C-S-G formula is not discarded, a much greater emphasis is placed on newer dances, such as the bourrée, gavotte, menuet, rondeau, and passepied. Here we can readily see the influence of Lully, who was the first to group these newer dances together from his theater works in order to form orchestral suites. ${ }^{185}$

Part of the dedicatory page of the Musicalisches Blumen-Büschlein reads: "allein auf das Clavicordium, oder Instrument eingerichte Parthyen.”" ${ }^{\prime 86}$ This provides us with a clue that Fischer first had the clavichord in mind when composing these works and that he had a more intimate and domestic intention for their use.

Stylistically, Fischer's keyboard writing was unlike anything else being written in Germany at the time. As Silbiger states:

The style of writing is greatly different from that of most previous harpsichord music: the style brisé is now the exception rather than the rule and, for the most part, even the lightest dances preserve linear part writing. A comparison with contemporary instrumental dances, in particular Fischer's own Le journal du printemps of 1695, shows that these pieces directly mimic the voice leading of instrumental music; indeed, there is the possibility that some might be transcriptions. ${ }^{187}$

\footnotetext{
${ }^{185}$ Silbiger, 205.

186 Apel, 590.

187 Silbiger, 205.
} 
Although proving Silbiger's last suggestion in the quotation above would be very difficult at best, nonetheless we can better understand the highly idiomatic nature of Fischer's compositions in the suite genre.

The most creative and original works in the Musicalisches Blumen-Büschlein are the preludes, and their originality lies in the fact that they go against so many of the prelude models that came before Fischer. They largely dispense with the French style brisé technique and opt instead for brevity and frequent pedal points. These are unusual traits indeed coming from a composer known for introducing "Lullyan" characteristics into German keyboard composition. ${ }^{188}$

While still being of interest, Fischer's Musikalischer Parnassus does not carry the level of import that the Musicalisches Blumen-Büschlein does; the former's innovations are more programmatic in nature rather than stylistic or structural. The Musikalischer Parnassus contains nine suites (Parthien), each of which carries the name of one of the Greek muses. Each suite starts with a prelude, with such titles as "Praeludium Harpeggiato," "Ouverture," "Toccatina," or "Tastada." Two suites follow the prelude with a classical pattern: No. 1 (Clio) with A-C-S-ballet-minuet-gigue, and No. 9 (Uranie) with A-C-S-gavotte-gigue-rigaudon-minuet-passepied. ${ }^{189}$

\footnotetext{
${ }^{188}$ Silbiger, 205-206.

189 Apel, 592.
} 
Example 7.5 Fischer: "Praeludium Harpeggiato" from the Clio Suite (Clio is the Greek muse of history). ${ }^{190}$

\section{Praeludium Farpeggiato.}
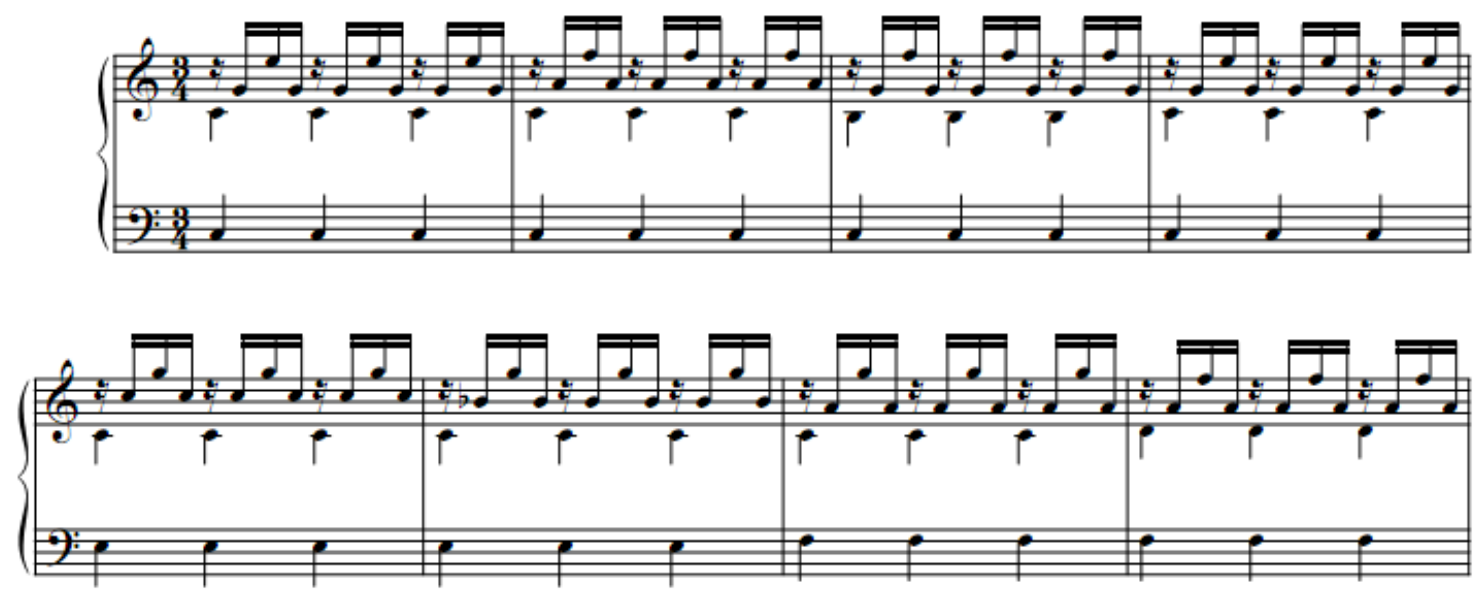

The other suites generally have an allemande after the prelude and then continue with other dances, sometimes including a gigue. Several times the minuet appears in the alternative arrangement of minuet I-minuet II-minuet I, which reappears in the works of the Classical Viennese masters as minuet-trio-minuet. ${ }^{191}$

\footnotetext{
${ }^{190}$ IMSLP.

${ }^{191}$ Apel, 589-592.
} 
Example 7.6 Fischer: "Menuet I" and "Menuet II" from Calliope Suite (Calliope is the muse of epic poetry). ${ }^{192}$
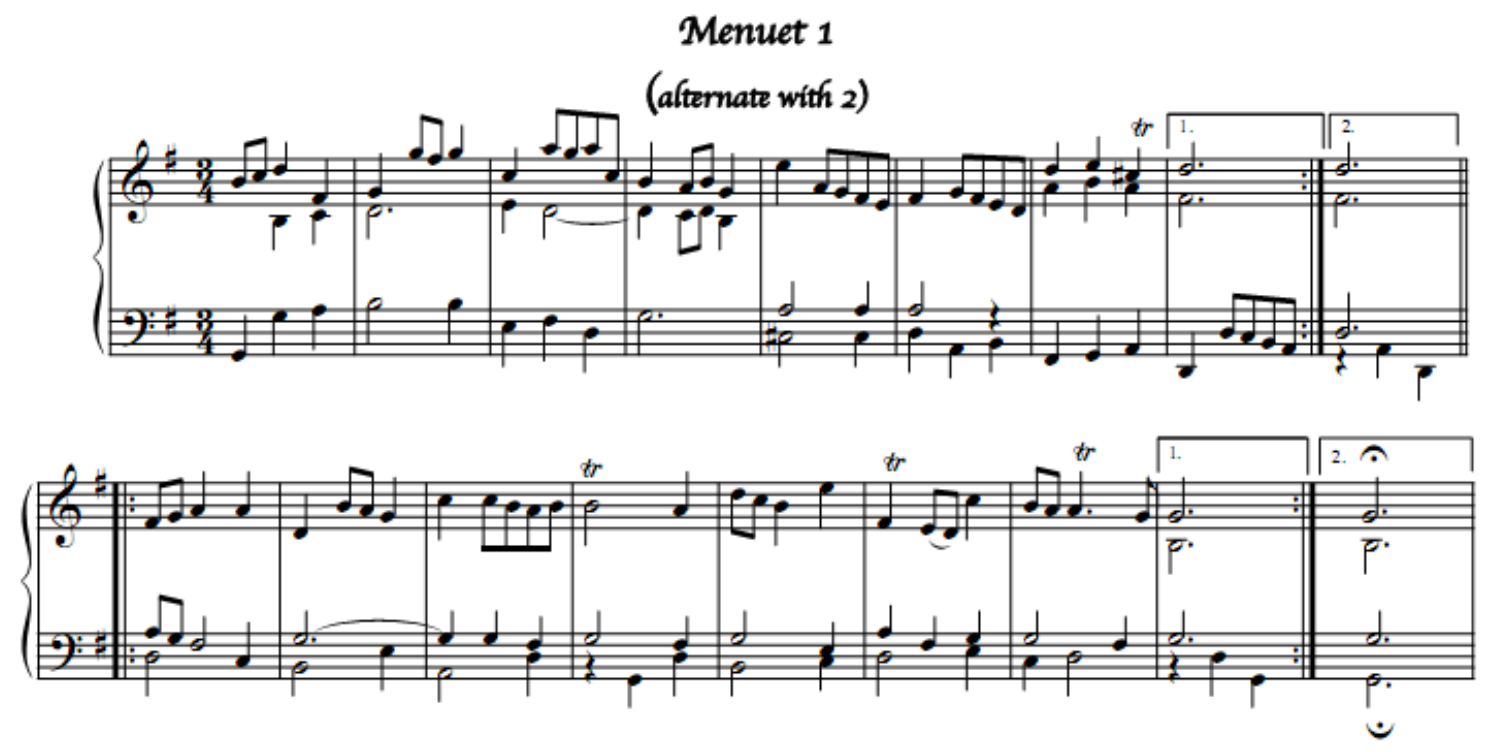

Menuet 2
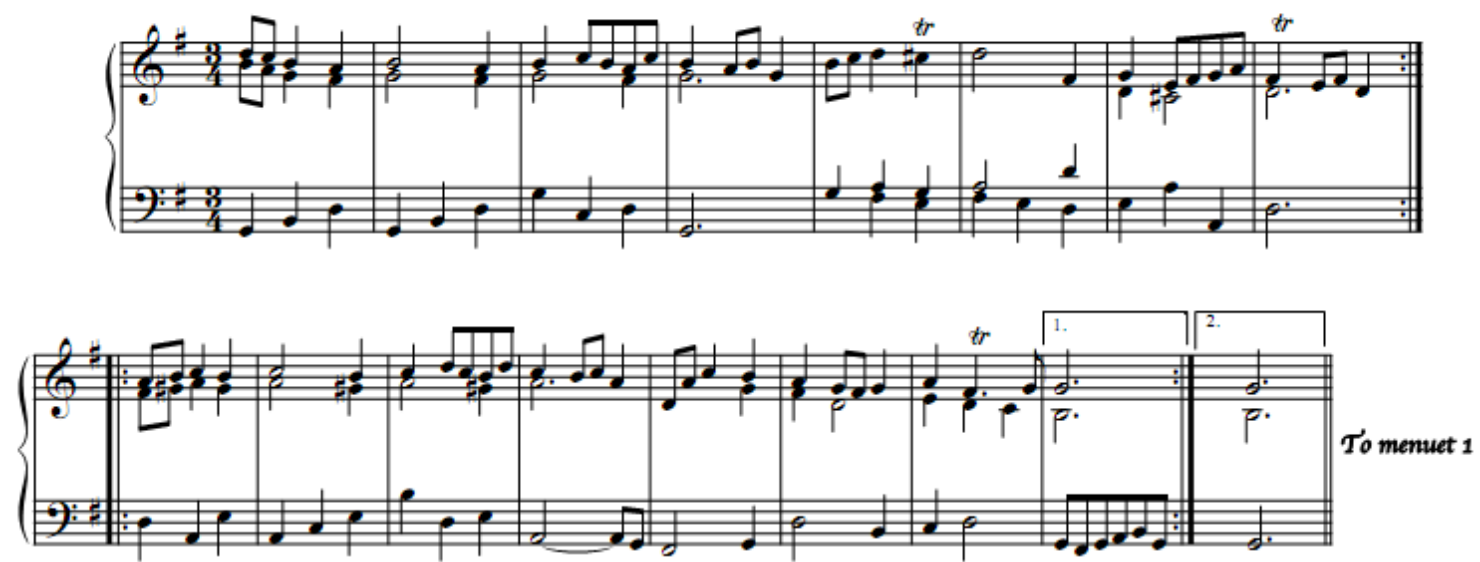

-Böhm-

Böhm's oeuvre of 11 keyboard suites demonstrates his ability to make innovations to the genre. While he closely adhered to the A-C-S-G "core," he also

${ }^{192}$ IMSLP. 
brought a newer "galant" style to his keyboard writing that included lyrical Italianate melodies (sometimes with variations and sometimes without). ${ }^{193}$

As stated above, Böhm followed the standard classical "core," but he also admitted some structural differences on occasion: in Suite No. 9 in F minor the gigue is omitted, in Suite No. 8 in F minor it is replaced by a chaconne, and Suite No. 10 in G major is introduced by a short prelude. In Suites No. 5 in E-flat major and No. 7 in F major the gigue is written in duple meter, as Froberger sometimes does. Suite No. 5 is very reminiscent of Froberger in other respects as well, especially in the allemande with its sixteenth rests. In Suites No. 3 in D minor, No. 6 in E-flat major, and No. 9 some of the movements are related by starting with variations of the same idea; in Suite No. 4 in D minor the variation principle runs through all of the movements (variation suite). ${ }^{194}$

Suite No. 2 in D major, however, represents a very different and innovative type of suite. It is probably the first example in keyboard music of a fully developed French ballet suite or, as Bach called it, the French overture. The movements of the work are as follows:

Suite No. 2

- Overture

- Air

- Rigaudon and Trio

- Rondeau

- Minuet

- Chaconne

The overture reflects the plan and style of Lully's ballet and opera overtures with three sections, the first and last being adagios, and the second a fugal allegro. Like the others,

\footnotetext{
${ }^{193}$ Silbiger, 210.

${ }^{194}$ Apel, 634-635.
} 
this movement shows a thorough familiarity with the French style and is a successful imitation of it. ${ }^{195}$

\section{-Kuhnau-}

In my estimation, Kuhnau is the best composer to discuss prior to looking into the contributions of Handel and Bach. Kuhnau's works epitomize many trends of the German Baroque and anticipate many of the developments of the early $18^{\text {th }}$ Century. All four of his keyboard publications survive:

1. Neuer Clavier Übung erster Theil. Bestehend in sieben Partien aus dem Ut, Re Mi, oder Tertia majore eines jedweden Toni ... 1689

2. Neuer Clavier Übung Andrer Theil, das ist: Sieben Partien aus dem Re, Mi, Fa, oder Tertia minore eines jedweden toni, benebenst einer Sonata aus dem B... 1692

3. Frische Clavier Früchte oder sieben Sonaten ... 1696

4. Musicalische vorstellung einiger biblischer Historien in 6 Sonaten ... 1700 196

The first two of Kuhnau's four publications concern us in this project, as the latter two do not contain any suites (Partitas). Clavier Übung I contains seven suites in the major keys of C, D, E, F, G, A, B-flat, while Clavier Übung II includes seven more suites in the minor keys of C, D, E, F, G, A, B. This diatonic ascent through major and minor keys presages Bach's Well-Tempered Clavier, in which the composer ascends chromatically through all major and minor keys. ${ }^{197}$

The basic arrangement of Kuhnau's suites is A-C-S-G, but the sarabande is replaced once by an aria (Clavier Übung I, Suite No. 6), and the gigue is replaced several

\footnotetext{
${ }^{195}$ Miner, C. "A Comparative Study of English, French, and German Keyboard Suites of the Sixteenth, Seventeenth, and Eighteenth Centuries." (MM thesis, University of South Dakota, 1968).

196 Apel, 667.

197 Apel, 667.
} 
times by a minuet, bourrée, or aria. Each suite begins with a substantial prelude, and Clavier Übung II, Suite No. 7 is probably one of the earliest instances of the following specific sequence, reflecting what would later become a common ordering for the late German Baroque keyboard suite, especially in Bach's music:

- Prelude

- Allemande

- Courante

- Sarabande

- Inserted dance of choice (I)

- Gigue

Example 7.7 Kuhnau: "Gavotte" from Clavier Übung II, Suite No. 7. This is the (I) (Inserted dance) between the "Sarabande" and "Gigue." This prelude-A-C-S-I-G ordering probably influenced Bach, as he repeatedly used it in his English Suites and Partitas. ${ }^{198}$
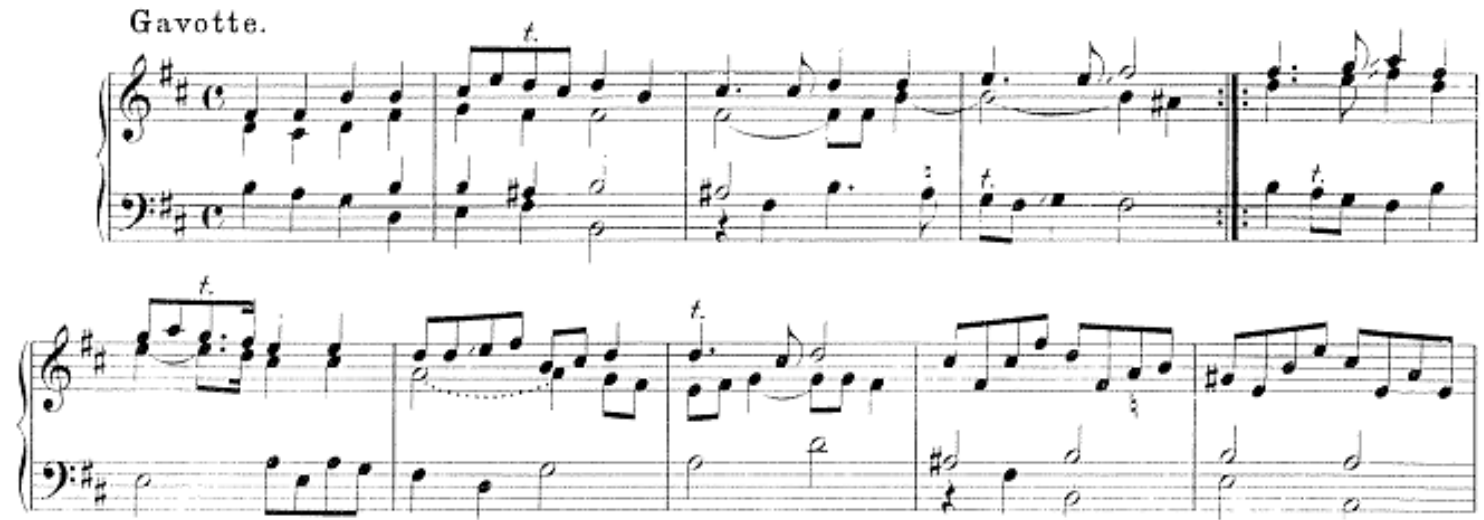

For his preludes Kuhnau generally chooses the form of a short toccata-like introduction followed by a fugal movement, which might also constitute a foreshadowing of Bach's Well-Tempered Clavier. In the preface to Clavier Übung II, Kuhnau draws attention to the fact that the fugues "usually involve countersubjects, so that not only

${ }^{198}$ IMSLP. 
beginners but also those who are adept at the clavier and at composition will find a challenge." 199

\section{-Handel-}

As one of the greatest composers to emerge from Germany during the Baroque or any other era, Handel needs no introduction. He was first and foremost a man of the theater, having written forty-six operas in addition to numerous oratorios. He was also a master of the instrumental style of the period, as is evidenced from his output of concerti grossi, sonatas, organ concertos, and incidental music.

When compared to the immensity of his overall output, Handel's keyboard music is relatively unimportant; but it is, nevertheless, a significant contribution to the literature of the period. In general, his keyboard pieces are rather brief compositions that he probably initially used for pedagogical purposes. ${ }^{200}$

Three substantial collections of Handel's keyboard music were published during his lifetime: eight Suites de Pièces (HWV 426-433) "printed for the Author" in 1720, nine more suites (HWV 434-442) in a "Second Volume" published by Walsh c. 1733, and Six Fugues from Walsh in 1735. A number of authentic suites did not appear in the published collections: these include the Partita in G major (HWV 450, c. 1700-1705) and the Suites in C major (HWV 443, c. 1700-1703), D minor (HWV 449, c. 1705), G minor (HWV 453, c. 1705-1706), B-flat major (HWV 455, c. 1706), D minor, and G minor (HWV 447, 452, c. $1738-1739){ }^{201}$

\footnotetext{
${ }^{199}$ Apel, 657.

${ }^{200}$ Gordon, S. A History of Keyboard Literature: Music for the Piano and Its Forerunners. (New York: Schirmer Books, 1996), 52.

${ }^{201}$ Best, T. "Handel's Keyboard Music." Musical Times 112, (1971).
} 
While the two major volumes of Handel's suites (1720 and 1733) were published in England, their overall style remains similar to the composer's keyboard writing prior to leaving Germany. In essence, they provide us with a glimpse of his creative youth and German heritage. Additionally, there are a number of sources available to suggest that Handel did much of his keyboard writing prior to leaving Germany rather than during his stay in England. One such source is an early collection of keyboard works published by Chrysander, entitled Klavierbuch aus der Jugendzeit. Many of the prototypes and initial versions of Handel's later publications while in England are to be found in this book. ${ }^{202}$

Example 7.8 Handel: “Allemande" from Suite in B-flat major from Klavierbuch aus der Jugendzeit. $^{203}$

\section{Suite.}
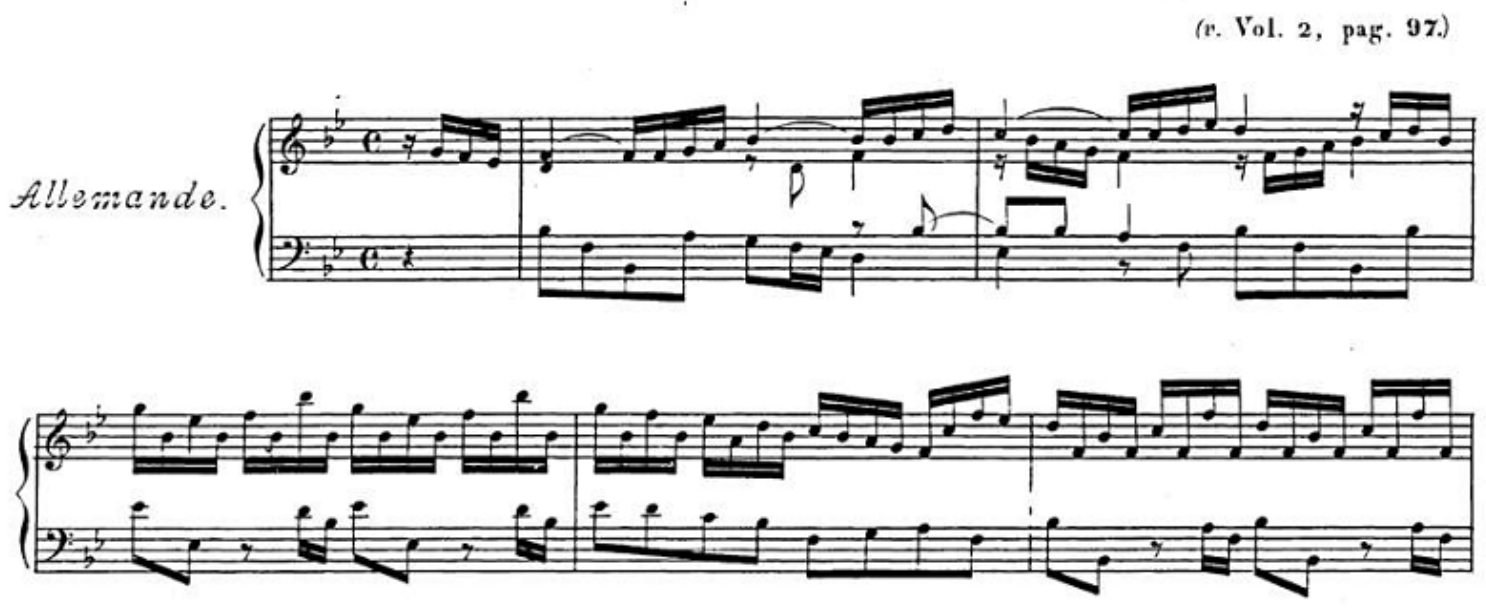

As mentioned above, Handel's first published instrumental music (1720) was a set of eight harpsichord suites, often referred to as the "Eight Great" suites. The key scheme among these suites provides for contrast: A major, F major, D minor, E minor, E major,

\footnotetext{
${ }^{202}$ Lang, P. George Frideric Handel. (Mineola, New York: Dover Publications, Inc. 1966), 657-658. ${ }^{203}$ IMSLP.
} 
F-sharp minor, G minor, F minor. These suites also vary with regard to arrangement of movements and the types of dances used: Suites 1, 2, 5, and 6 (HWV 426, 427, 430, and 431) contain four movements each; Nos. 4 and 8 (HWV 429 and 433), five movements; and Nos. 3 and 7 (HWV 428 and 432), six movements. Suites 1, 5, 6, and 8 are the only ones to open with preludes. Other opening movements include an adagio (No. 2), a presto (No. 3), and a French overture (No. 7). ${ }^{204}$

Suite No. 5 is probably Handel's most well-known keyboard composition. It bears the nickname "Harmonious Blacksmith" due to the theme of the "Air and Variations" that conclude the piece (probably based on a popular English tune of the day), and its compact, four-movement structure is well-balanced and effective:

Suite No. 5 in E major

- Prelude

- Allemande

- Courante

- Air and Variations

Example 7.9 Handel: "Air" from the final movement of Suite No. 5 in E major. Please note that this example is taken from the original engraving published by Walsh. This is exactly how the first performers of this piece would have seen it upon returning from the music shop. In particular, notice how the D-sharp is left out of the key signature. ${ }^{205}$

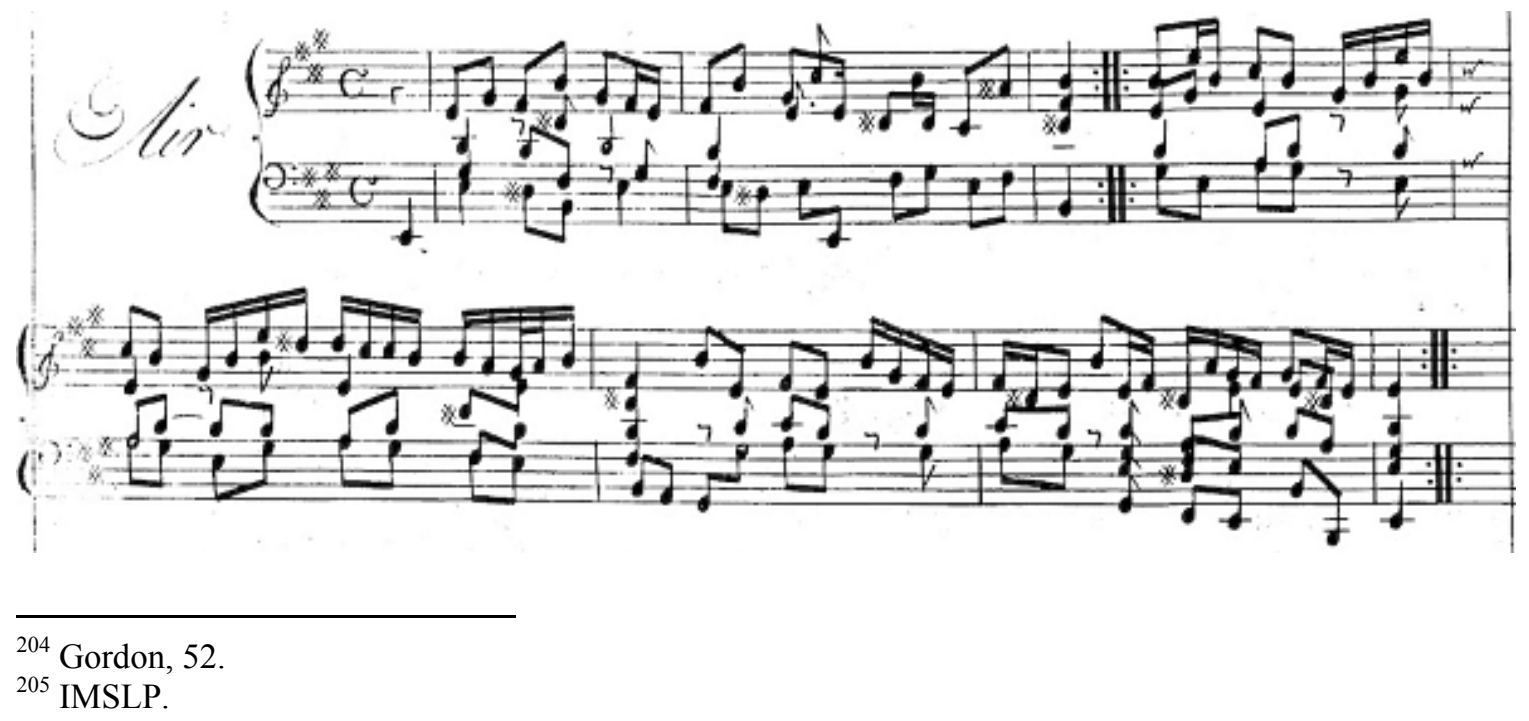


An important observation to make regarding this suite and many others by Handel is that he did not take the once-rigid, classical core of dances literally; for example, if we look at the next two suites from the same publication (Nos. 6 and 7), we see the following ordering:

Suite No. 6 in F-sharp minor (a highly unusual key for the time)

- Prelude

- Largo

- Allegro

- Gigue

Suite No. 7 in $G$ minor

- Ouverture

- Andante

- Allegro

- Sarabande

- Gigue

- Passacaille

-Bach-

The keyboard works of Bach represent Germany's greatest contribution to Baroque keyboard literature and merit more study than those by any of the other composers discussed thus far. Not only did Bach write a considerable number of works for the clavier, but he also maintained a consistently high level of quality throughout. His major contributions to the keyboard suite are to be found in three sets of six suites each, which we know as the English Suites, French Suites, and Partitas; several miscellaneous suites are also scattered throughout his oeuvre.

While Bach worked for Leopold of Cöthen (1694-1728) he wrote the sets of pieces known as the English Suites and French Suites. The first five French Suites also appear as teaching material in the 1722 version of the Notenbüchlein für Anna 
Magdalena Bach. The composition dates of the suites have not been determined with certainty, but it is generally believed that the English Suites were written before the French Suites.

All of the English Suites present a prelude before the allemande. The preludes of Suites Nos. 2-6 are lengthy pieces that contain both imitative sections and sequences reminiscent of contemporary Italian orchestral writing. The prelude of English Suite No. 1 is more modest, along the lines of those found in the Well-Tempered Clavier, and is therefore reminiscent of Kuhnau's Clavier Übung II mentioned above. It uses, incidentally, a theme that some scholars believe to have been borrowed, the material showing similarity to gigues by both Dieupart and Le Roux. ${ }^{206}$

${ }^{206}$ Gordon, 59. 
Example 7.10 Bach: "Prelude" from English Suite No. 1 followed by the "Gigue" from Le Roux's A major Suite. Not only does Bach use a melody quite similar to that used in the Le Roux example, but he also employs the same key and meter. ${ }^{207}$

\section{SUITE I.}
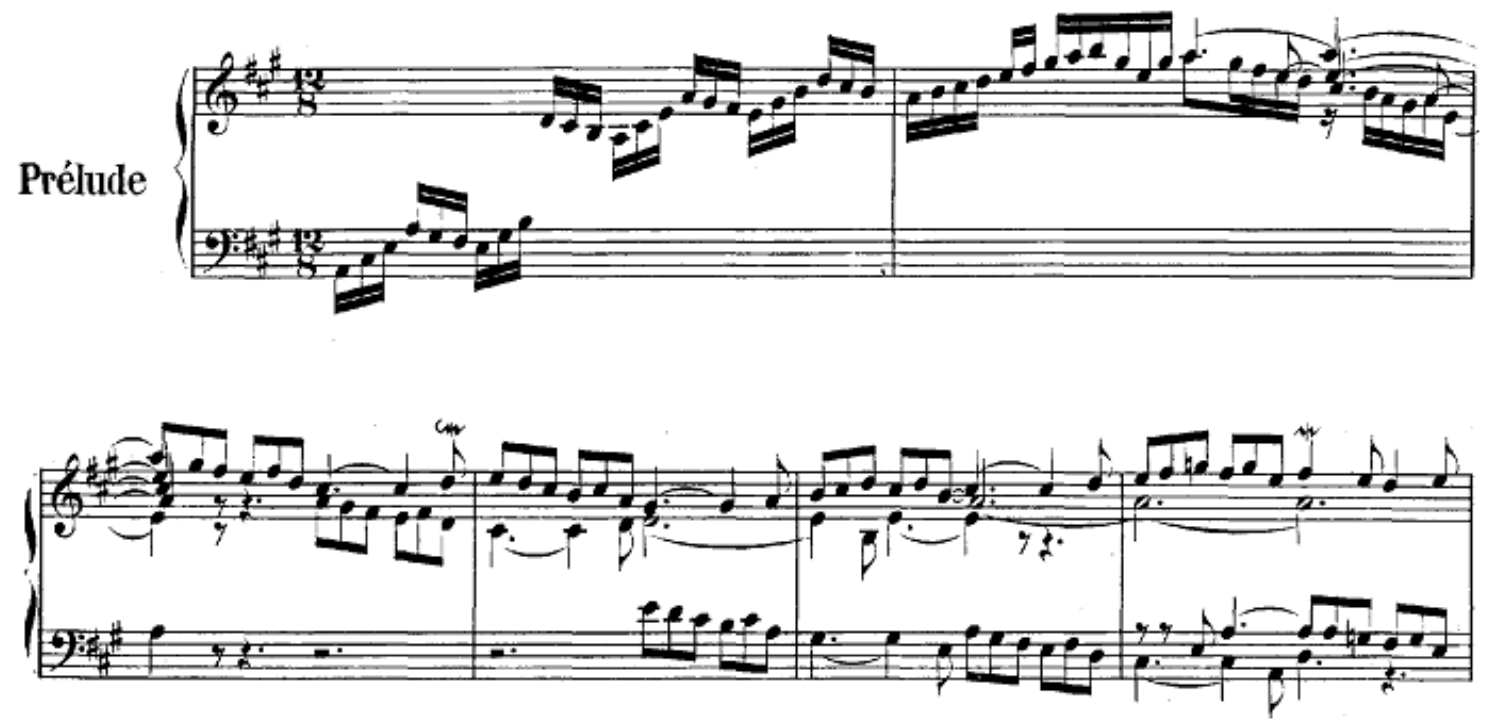

Gigue

Gaspard Le Roux
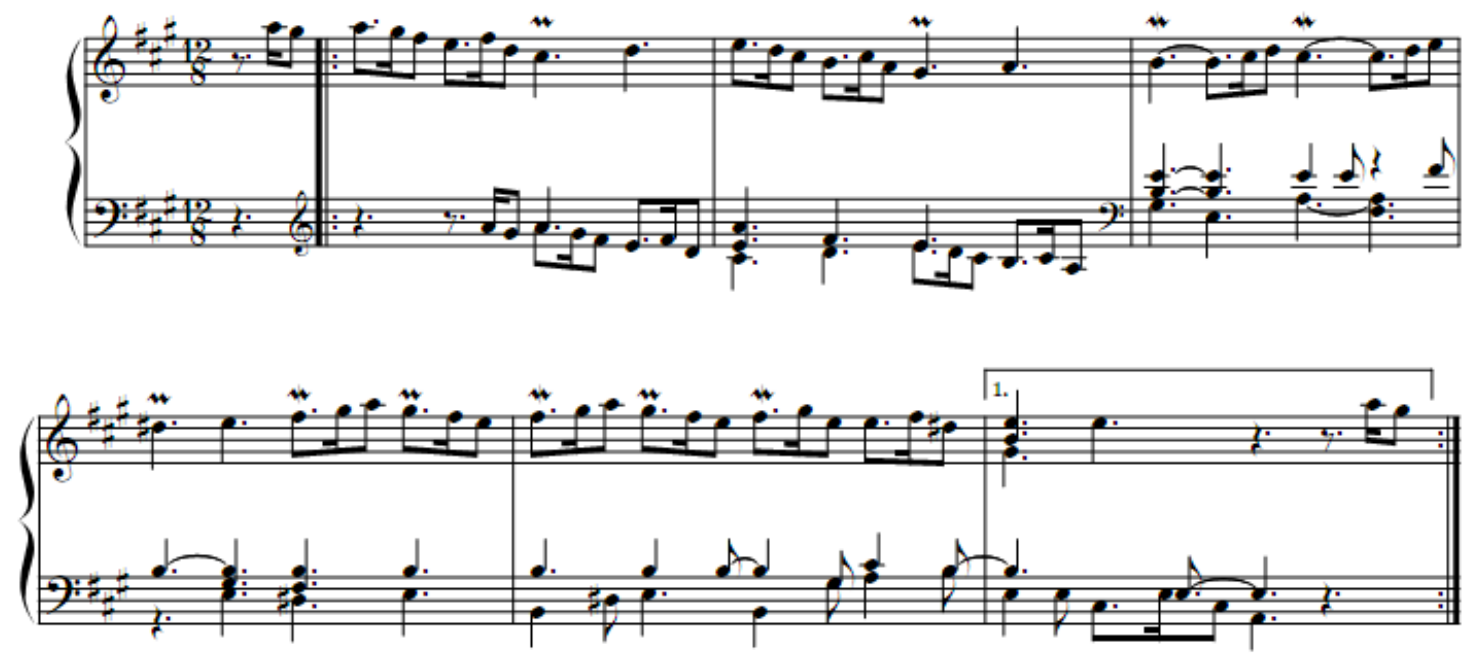

${ }^{207}$ IMSLP. 
The dance movements are almost always cast in binary form, each part sharing the same thematic materials and each marked to be repeated. Modulation to the dominant (or sometimes to the relative major for movements in minor keys) typically occurs somewhere near the end of the first part. The second part returns to the tonic, usually closing with material heard near the end of the first part.

Bach's allemandes exhibit typical characteristics of the dance as it evolved from the $17^{\text {th }}$ Century: figural writing in contrapuntal style, the use of duple meter at a moderate tempo, and the opening of each section with an upbeat. ${ }^{208}$

Example 7.11 Bach: “Allemande” from English Suite No. 3. ${ }^{209}$

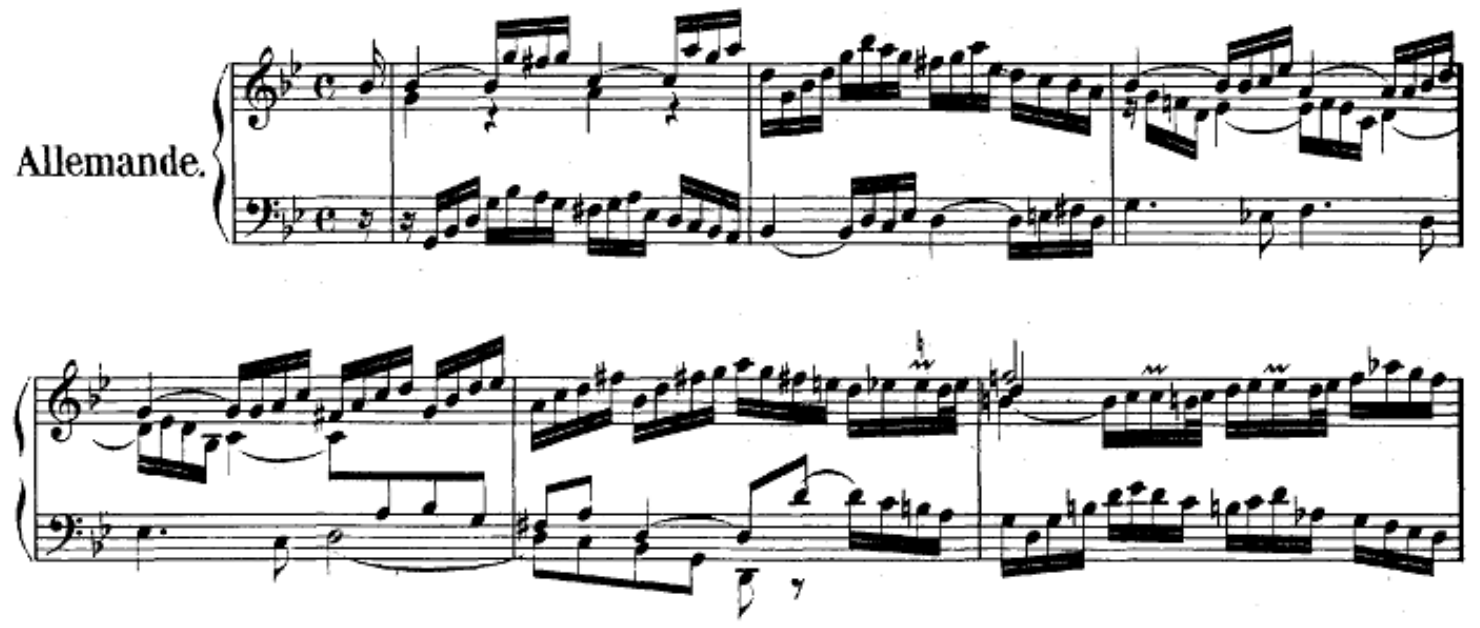

The French courante is used in all of the English Suites and two of the French Suites (Nos. 1 and 3). This style typically uses a compound meter as well as a

\footnotetext{
${ }^{208}$ Dürr, A. "The Historical Background of the Composition of J. S. Bach's Clavier Suites." Bach 16, No. 1 (1985).

${ }^{209}$ IMSLP.
} 
contrapuntal texture. Bach consistently employed a time signature of $3 / 2$ with the exception of the courante in French Suite No. 3, where 6/4 is used instead.

Example 7.12 Bach: "Courante” from French Suite No. 3. ${ }^{210}$
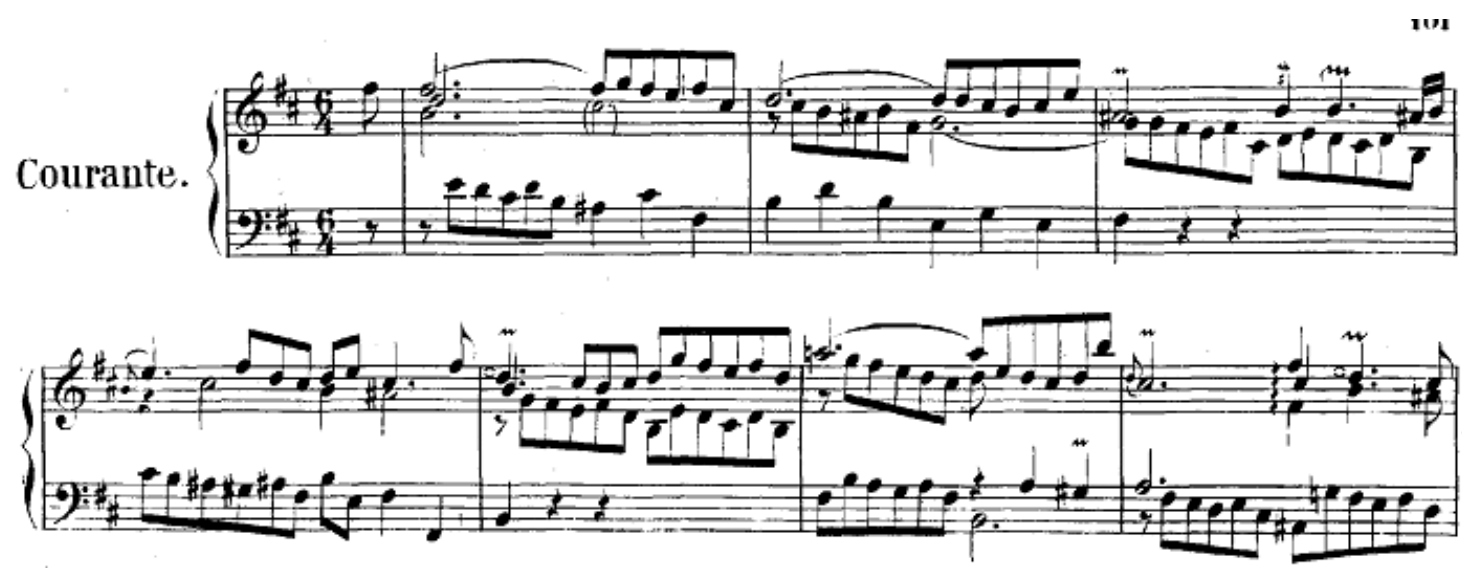

He also adhered to arranging each measure metrically into three divisions most of the time, with strong beats on one, three, and five. At cadence points, however, he consistently shifted the emphasis to divisions of two, with strong beats on one and four. $^{211}$

Bach's sarabandes are especially well-written compositions that provide an ideal model for the sarabande as a serious instrumental art form. Their slow, expressive nature invites ornamentation, and Bach provided notated ornaments in the English Suites No. 2 in A minor (BWV 807), No. 3, as well as in No. 6, where the second version is called a "double.,"212

\footnotetext{
${ }^{210}$ IMSLP.

${ }^{211}$ Gordon, 60.

${ }^{212}$ Gordon, 60 .
} 
Example 7.13 Bach: "Sarabande" and ornamented "Double" from English Suite No. 6. ${ }^{213}$
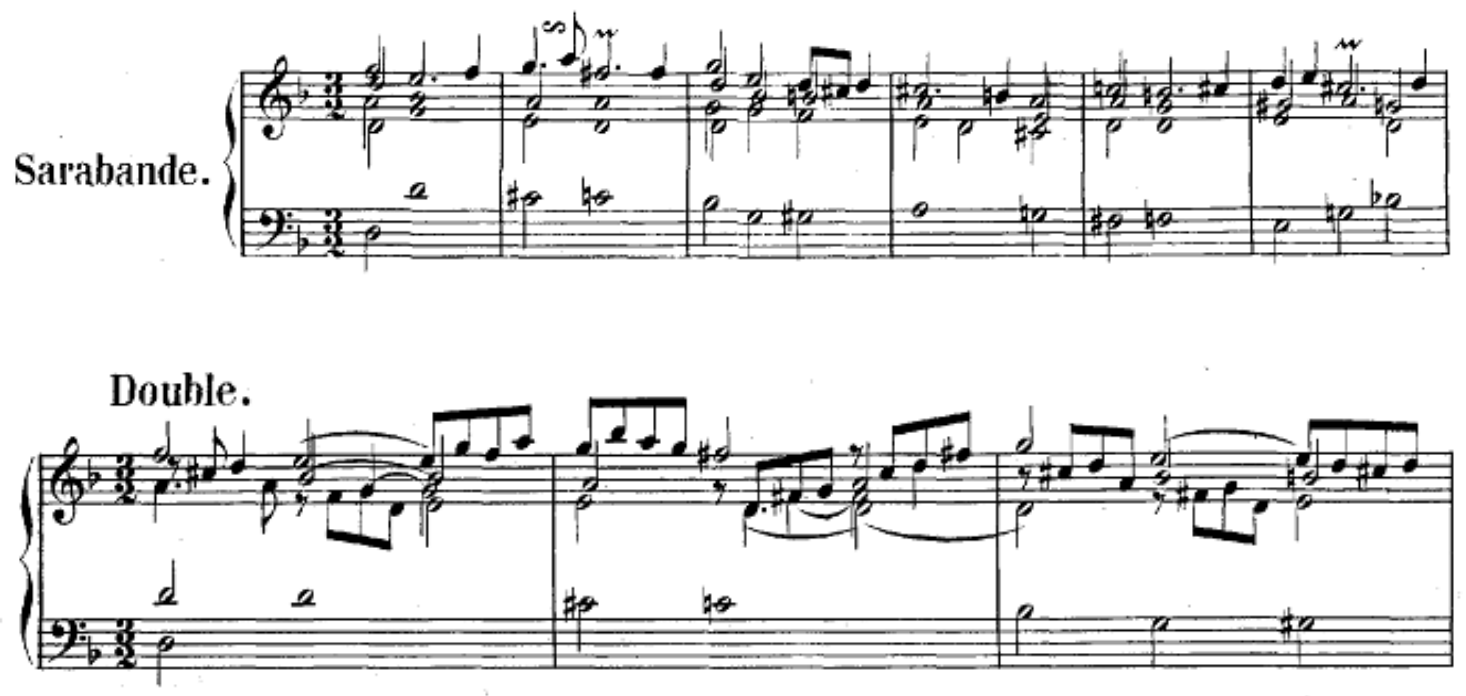

For the optional dances that are inserted between the sarabande and the final gigue, Bach frequently turned to the bourrée, gavotte, minuet, and passepied. Less frequently used are the anglaise, aire, loure, and polonaise, the early version of the Polish court dance in $3 / 4$ that later became a heroic symbol of Polish nationalism in the hands of Frederic Chopin (1810-1849). ${ }^{214}$

\footnotetext{
${ }^{213}$ IMSLP.

${ }^{214}$ Schulenberg, D. "Composition and Improvisation in the School of J. S. Bach," In Bach Perspectives I (1995), Ed. by Russell Stinson.
} 
Example 7.14 "Polonaise" from Bach's French Suite No. 6 and mm. 9-12 of Chopin's Polonaise in B-flat major (posthumous). While it is outside the scope of this research project to discuss how much Bach may or may not have influenced Chopin, it is important to recognize that Bach was among the first composers to write a polonaise for solo keyboard. The similarities between the steady left-hand figuration and right-hand passagework of these two compositions written over a century apart are difficult to ignore and provide further testimony to Bach's status and influence. ${ }^{215}$
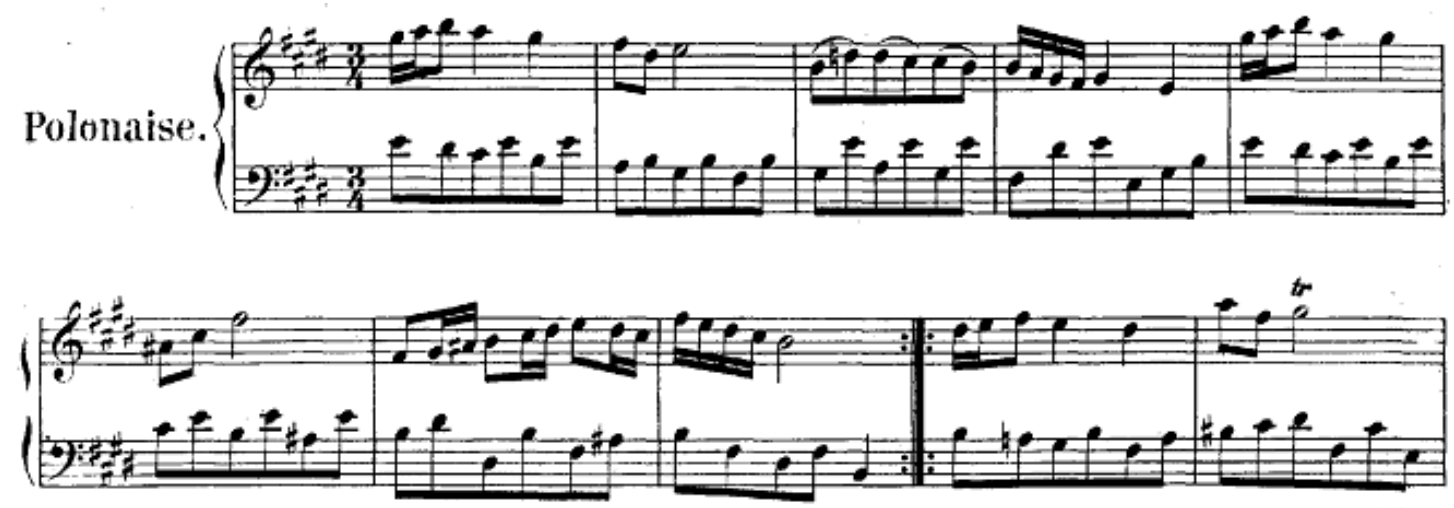

Chopin: Polonaise in B-flat major (mm. 9-12).

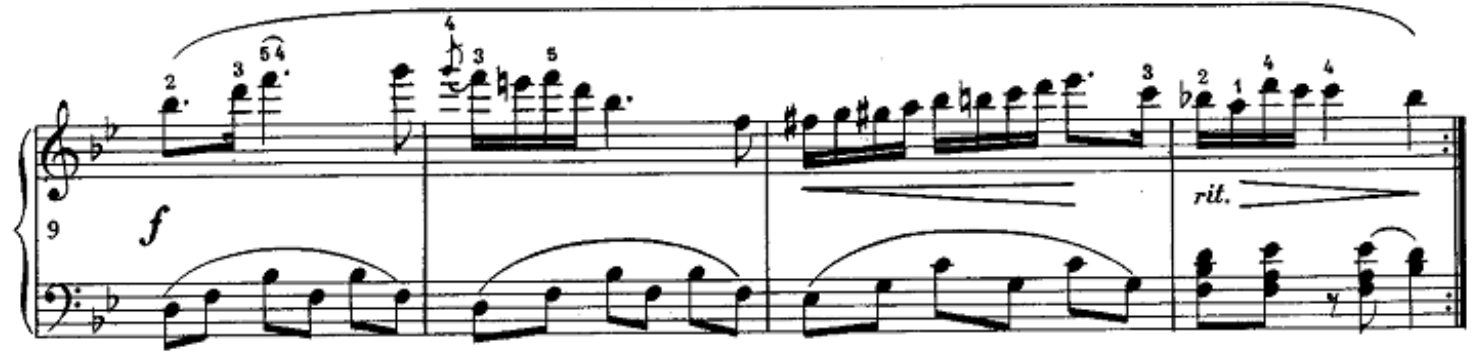

Bach's gigues tend to adhere to the characteristics established by the German and French composers who came before him. Only twice, in the French Suite No. 1 and the later Partita No. 1, does Bach use duple meter in a gigue, and in both cases a triplet-like motion is maintained in the music. Additionally, as was the case with many $17^{\text {th }}$-Century

${ }^{215}$ IMSLP. 
keyboard composers, Bach often used an inversion of the opening motive to open the second section. ${ }^{216}$

Example 7.15 Bach: Opening of the first and second sections of the "Gique" from English Suite No. 1. Notice how the opening motive is inverted in the second section. ${ }^{217}$
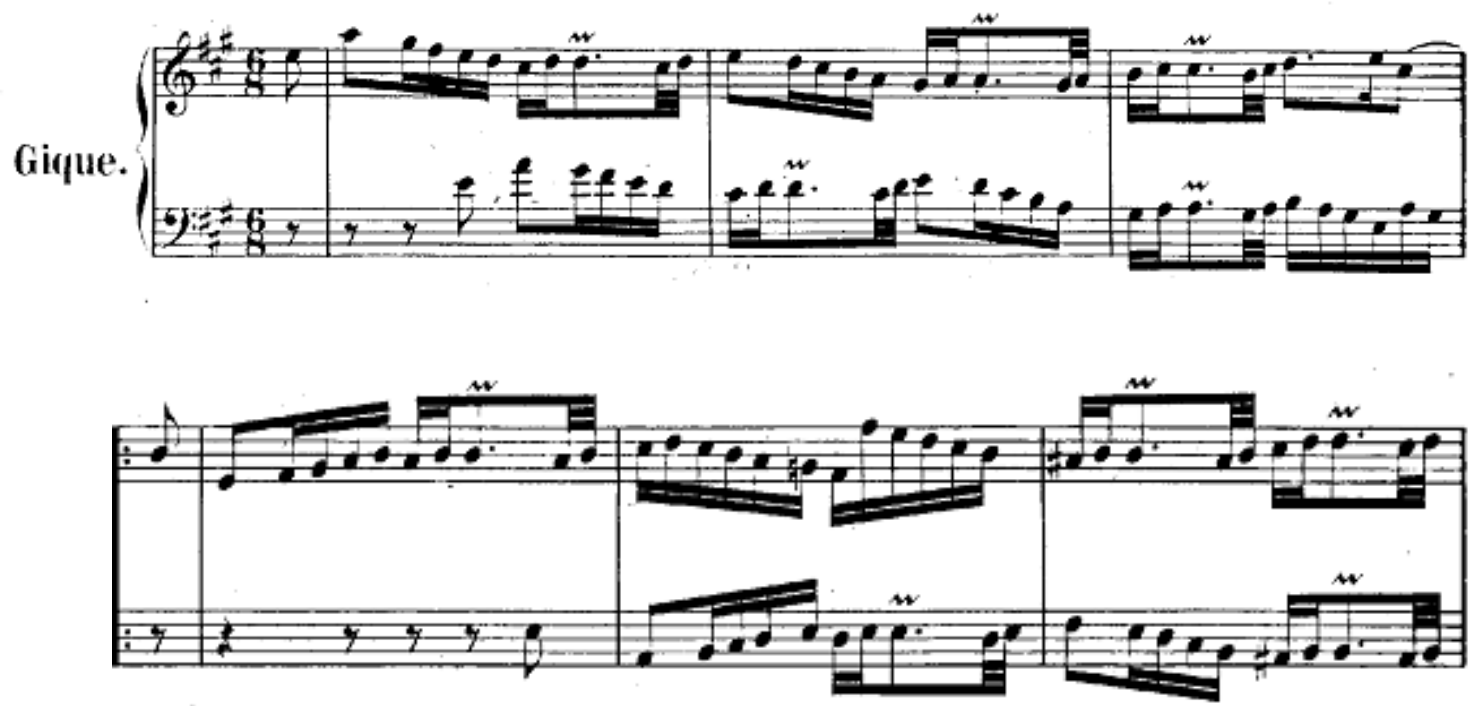

The six Partitas were published during Bach's Leipzig period as Clavierübung I, and, as indicated above, Bach uses a format similar to that used by Kuhnau in his Clavier Übung of 1689-1692. Based on the idea of the dance suite, Bach's six sets of pieces are in B-flat major, C minor, A minor, D major, G major, and E minor. Each Partita opens with an introductory movement; in chronological order the opening movements are entitled "Praeludium," "Sinfonia," "Fantasia," "Ouverture," "Praeambulum," and "Toccata," respectively. The "Ouverture" and "Sinfonia" feature stately dotted rhythms typical of the French overture.

${ }^{216}$ Gordon, 61.

${ }^{217}$ IMSLP. 
Additionally, the Partitas each include an allemande, a courante, and a sarabande. All of them end with a gigue except Partita No. 2 in C minor (BWV 826), which concludes with a highly contrapuntal capriccio. The gigue of Partita No. 1 is of the "Italian" type, featuring rapid figuration that requires constant crossing and uncrossing of the hands. Unusual optional movements also occur: a "rondeau" and "caprice" in Partita No. 2 and a "burlesca" and "scherzo" in Partita No. 3. ${ }^{218}$

Example 7.16 Bach: "Gique" from Partita No. 1. Notice the constant hand-crossing necessary to perform this work. ${ }^{219}$

Gique.
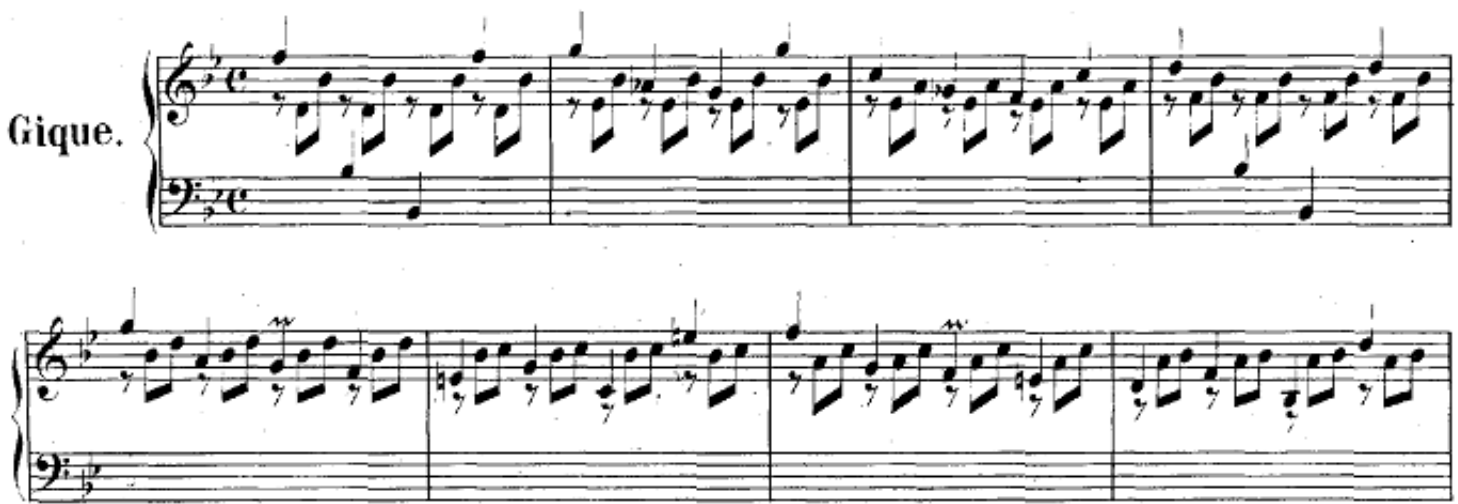

A separate Partita in B minor was published as part of Bach's Clavierübung II.

Known in English as the French Overture, its full title is Ouvertüre nach franzöischer Art [Overture in the French Style]. The pattern of its movements is freer and more expansive than those of the other Partitas; it opens with the overture from which it gets its title, a

218 Gordon, 66.

219 IMSLP. 
dotted-rhythm adagio followed by a fugal allegro. A courante, two gavottes, two passepieds, a sarabande, two bourrées, a gigue, and an echo follow the overture. ${ }^{220}$ As stated earlier, the keyboard works of Bach represent the best of what German Baroque keyboard music has to offer, and his contribution to the suite genre through his English Suites, French Suites, Partitas, and other works is virtually impossible to estimate. However, it is also important to recognize that much of what Bach achieved could not have taken place without the composers who came before him. Beginning with the innovations and mastery of Froberger and leading through a succession of highly gifted composers to Kuhnau and Handel, Bach was able to inherit an already impressive musical legacy and make enormous contributions to the Baroque keyboard suite.

\footnotetext{
${ }^{220}$ Koster, J. “The Harpsichord Culture in Bach's Environs," Bach Perspectives IV: The Music of J. S. Bach: Analysis and Interpretation (1999), Ed. by David Schulenberg.
} 


\section{Conclusion}

The term "suite" first emerged in France in the mid- $16^{\text {th }}$ Century and was used to describe a group of rustic, instrumental dances known as branles. With the passage of time, stylized dances with specific characteristics replaced the rather generic branles and served to create suites that took on a defined but highly flexible structure. Eventually, the suite came to be viewed as a composite musical form with a conventional ordering of pieces.

As we moved into the $17^{\text {th }}$ Century, the suite incorporated a "core" of three specific dances: Allemande (A)-Courante (C)-Sarabande (S). Sometimes a gigue (G) was included in this combination, and oftentimes a prelude preceded the allemande.

Additionally, many other stylistic dances such as the bourrée, passacaglia, chaconne, menuet, rondeau, and passepied were appended to the "core" dances.

Key unity (the placement of all movements in the same key) became a standard characteristic of the instrumental suite as well, and all suites consisted of dance forms with the possible exception of the prelude. It would also appear that at least three movements - frequently A-C-S, but usually many more - were necessary to satisfy the Baroque Era's definition of a suite.

France was the first country in which the suite for keyboard flourished; indeed, it would appear that the suite was one of the few genres of keyboard music propagated by French musicians during the $17^{\text {th }}$ Century. Several important manuscript collections circulated throughout France at the time, and the two most influential collections were 
known as the Parville and Bauyn manuscripts. They consist almost exclusively of dance forms, with some of the dances grouped in performance orderings and others by genre. Among the composers represented in these collections are Froberger, Frescobaldi, Hardel, Louis Couperin, Chambonnières, and La Barre.

Aside from manuscript collections, French composers - such as Chambonnières, d'Anglebert, and Lebègue - published their keyboard works in books known as Pièces de Clavecin. These books contained suites ranging from four to twenty-one movements, and many of the suites were preceded by unmeasured preludes, a highly improvisatory style of prelude composition particularly utilized by the French.

Chambonnières was one of the first major figures to cultivate the French keyboard suite. Upon his death, he left two volumes of Pièces de Clavecin containing approximately 60 keyboard pieces. Additionally, he tutored many pupils, including Louis Couperin and Hardel, who in turn made significant contributions to the suite genre.

As France moved into the $18^{\text {th }}$ Century, its keyboard composers gradually turned away from the use of unmeasured preludes and replaced them with more strictly notated preludes. Often, the overall style and fluidity of the unmeasured prelude remained, but composers exerted greater control over what notes were actually performed. The gigue also became a standard movement of the classical "core" of dances in the harpsichord suite, although where it appeared in a suite was subject to the composer's taste.

The first half of the $18^{\text {th }}$ Century was a period of intense activity for French composers of Pièces de Clavecin. Important collections were published by Dieupart, Clérambault, Dandrieu, Le Roux, La Guerre, Marchand, and Rameau, among others. 
Their works are also representative of the stylistic transition from the $17^{\text {th }}$ to the $18^{\text {th }}$ Centuries in French keyboard composition.

The two most important composers of French keyboard suites in the $18^{\text {th }}$ Century were Rameau and François Couperin. Rameau published three books of harpsichord pieces containing suites. These date from 1706, 1724, and 1728; an additional publication in 1742 did not contain suites. Rameau's suites loosely adhere to the A-C-S-G model but also incorporate a number of other stylistic dances in addition to the "core." Following the manner of François Couperin, some of Rameau's dance movements were provided with programmatic titles that describe the dance's nature or character.

François Couperin's production of keyboard suites (ordres) far outstripped that of Rameau or any other French composer. In fact, Couperin's reputation as one of the Baroque Era's great composers rests almost entirely on his contribution to solo keyboard literature. Couperin published four books of harpsichord works containing a total of 27 ordres, and some of the ordres consisted of as many as 20 movements or more. He was the first to abandon partially and at times completely the traditional dance names of movements and supply programmatic titles instead. The consistently high quality and level of inventiveness of Couperin's keyboard writing places him in a position of foremost importance in the realm of French Baroque keyboard composition. One may safely view Couperin as being the greatest French keyboard composer prior to Claude Debussy (1862-1918), who incidentally wrote several keyboard suites as well. Additionally, another great French composer and peer of Debussy, Maurice Ravel (18751937), thought highly enough of Couperin to compose and dedicate a major, multimovement piano suite to him, Le Tombeau de Couperin. 
Unfortunately, England did not possess a major, towering figure for keyboard composition during the Baroque Era. England's greatest native musical genius, Purcell, died at the age of 35 and did not place much emphasis on keyboard composition, opting instead for vocal music, such as welcome odes, anthems, and theater music/opera. What he did compose for keyboard, however, is generally of high quality.

As was the case with France, several major keyboard collections circulated throughout Baroque-era England, playing a very influential role for professional and amateur musicians alike: Musick's Hand-maide and Melothesia. Musick's Hand-maide (1663) represents the first serious attempt made by the English to group keyboard dances into suites. Approximately 80 pieces are to be found in Musick's Hand-maide, with many different composers contributing to the project.

Melothesia (1673) contains 61 pieces for keyboard, many of which were written by Locke. The suites typically consist of four to five movements and generally adhere to the standard $17^{\text {th }}$-Century A-C-S model. Frequently a prelude was added to the beginning of the suite while an extra dance of English character was added to the end.

The two most important English Baroque composers of keyboard suites were Locke and Purcell. The majority of Locke's keyboard output may be found in Melothesia, including four of his five suites. Locke's suites established the norm for keyboard suite composition in England, and they also demonstrated the influences of French unmeasured preludes and Froberger's compositional style.

As stated earlier, Purcell was England's greatest composer in the $17^{\text {th }}$ Century, but he left us little in the way of keyboard music. Eight suites were published posthumously in 1696; each consists of three to four movements, adhering to the A-C-S core. A prelude 
appears at the beginning of every Purcell suite and only a few additional, non-core dances are employed - the minuet and hornpipe.

Other composers - such as Blow, Draghi, and Clarke - made contributions to the English keyboard suite, but the artistic value of their work is not on a par with Locke and Purcell. However, the most important contributor to the Baroque-era suite in England was Handel, a German composer who spent the last 47 years of his life in England. We shall discuss his contributions below.

No country or region contributed more to the propagation of the Baroque keyboard suite than Germany. Almost every important German composer of the day wrote keyboard music, and often his genre of preference was the suite. While many Germans wrote keyboard suites, some of the more important contributors include Froberger, Reincken, Fischer, Böhm, Kuhnau, Handel, and Bach.

Froberger was the first German composer of significance to write keyboard suites, and he ultimately became the dominant German keyboard composer of the $17^{\text {th }}$ Century. He treated the A-C-S-G "core" as a fixed unit, thus creating a model for both his contemporaries and his imitators to follow. Froberger's compositional traits include style brisé (a technique derived from French lutenists); he also uses contrapuntal part-writing that is reinforced by thematic imitation, and repeated, binary-form sections within the dances.

Reincken produced eight keyboard suites that rigidly adhere to the A-C-S-G structure. As was the case with Froberger, Reincken liberally employed style brisé 
technique throughout his dance movements, especially the sarabandes. He also enlarged the gigue in terms of proportion and artistic merit.

Fischer left two major works that contain valuable contributions to the suite genre: Musicalisches Blumen-Büschlein and Musikalischer Parnassus. The Musicalisches Blumen-Büschlein contains eight suites that only loosely adhere to the A-C-S-G model and introduce many of the dances found in Lully's orchestral suites: bourrée, gavotte, menuet, rondeau, and passepied. Essentially, Fischer was responsible for introducing the "Lullyan" aesthetic into German keyboard music. Stylistically, the suites move away from the style brisé technique of their predecessors and rely on linear part writing that mimics the voice leading of instrumental music.

Böhm composed 11 keyboard suites that closely follow the A-C-S-G model and also bring a "galant" element to keyboard suite composition, including lyrical, Italianate melodies and variation techniques. Böhm also pioneered the French ballet suite for harpsichord, consisting of the following movements: Overture, Air, Rigaudon and Trio, Rondeau, Minuet, and Chaconne.

Kuhnau published two books of eight suites (partitas) each:

- Neuer Clavier Übung erster Theil. Bestehend in sieben Partien aus dem Ut, Re Mi, oder Tertia majore eines jedweden Toni ... 1689 (Clavier Übung I)

- Neuer Clavier Übung Andrer Theil, das ist: Sieben Partien aus dem Re, Mi, $\mathrm{Fa}$, oder Tertia minore eines jedweden toni, benebenst einer Sonata aus dem B ... 1692 (Clavier Übung II).

These suites basically follow the A-C-S-G formula with occasional substitutions for the original dances. Kuhnau is also largely responsible for the development of the following specific order of dances in the keyboard suite: Prelude (P)-Allemande (A)-Courante (C)- 
Sarabande (S)-Inserted Dance (I)-Gigue (G); this slight expansion of the traditional $18^{\text {th }}$ Century "core," with an optional dance inserted specifically between the sarabande and gigue, became very popular among composers of keyboard suites, especially Bach.

Handel, like Purcell, was one of the major Baroque masters who wrote keyboard music of quality but did not focus on keyboard composition as an a major part of his oeuvre. Handel's most important collection of keyboard suites (and the only one receiving his full editorial approval) was published in England in 1720 and came to be known as the "Eight Great" Suites. These suites provide key contrast and incorporate a wide variety of dance forms and movements; the traditional "core" is only occasionally followed. Next to those by Bach, Handel's "Great" suites are the most popular lateBaroque keyboard works of their kind.

Germany's most significant contribution to European Baroque keyboard literature is found in the music of Bach. Unlike Handel, Bach made keyboard composition and publication one of his priorities. His clavier works continue to be a staple in the teaching studio and the concert hall, and they have found a permanent place in the harpsichordist's and pianist's repertories. Bach's most important contribution to the suite genre comes in the form of three sets of six pieces each: The French Suites, the English Suites, and the Partitas. A number of other miscellaneous suites, such as the Overture in the French Style, may also be found throughout his oeuvre. All of these works are of incomparably high quality and have rightfully earned their place among the best keyboard repertoire of today. 
In summary, for over one hundred years during the Baroque Era, the suite was one of the most prominent genres in keyboard composition, and virtually every Baroque keyboard composer of significance from France, England, and Germany contributed to its propagation. While each of these countries developed its own stylistic approach to suite composition, it is also important to consider the ways in which these countries influenced each other and appropriated various aspects of one another's handling of the genre.

I feel that the Baroque keyboard suite represents the first large-scale keyboard genre to reflect a high degree of stylistic cross-fertilization between major European regions and beyond. Whether through a composer's individual travels, the transference of musical trends from one royal court to another, or the dissemination of manuscripts and printed collections, the suite was made to absorb any number of structural and characteristic influences throughout its development.

Individual keyboard dances and dance pairs, such as the pavane and galliard, had been in use throughout Renaissance- and Early-Baroque-Era Europe, but the suite served as an umbrella under which to gather a collection of these dances whose origins might lie as far away as the New World (as was the case with the zarabanda). As the Baroque Era progressed, the overall loose construction and style brisé of the French made a lasting impression on composers in England and Germany, while the refined and tasteful compositions of Locke and Purcell made a skillful (if limited) contribution to music on the Continent. Froberger and his German compatriots then created a more rigid "core" of dances that absorbed many French musical concepts but also added a greater degree of German contrapuntal refinement. 
Lastly, we have the works of Bach, which are arguably the crowning achievement of Late-Baroque keyboard suite composition. Bach was able to absorb the best of what had artistically taken place before him and employ it in his English Suites, French Suites, Partitas, and numerous other suite compositions. Influences and characteristics described in almost every section of the foregoing chapters on France, England, and Germany may be found in Bach's works, and his suites serve as a brilliant summary of an era that for all practical purposes concluded with his death. 


\section{Index of Musical Examples}

1. Example 3.1 François Couperin: "Rondeau" from Ordre No. 1, "Les Sylvains," 13.

2. Example 4.1 Chambonnières: Allemande from Pièces de Clavecin. Vol. II (1670), 21.

3. Example 4.2 Allemandes by Froberger: Suite No. 7 in E minor and Bach: Partita No. 6, 22-23.

4. Example 4.3 Louis-Claude Daquin (1692-1722) "Courante" from Deuxiême Suite (1735), 24.

5. Example 4.4 Bach: "Courante” from Partita No. 5, 26.

6. Example 4.5 Purcell: "Sarabande" from Suite in G major (Z. 661), 27.

7. Example 4.6 Bach: "Sarabande" from Partita No. 5, 28.

8. Example 4.7 Fischer: Opening measures of the "Gigue" from Calliope Suite in Musicalischer Parnassus, followed by the opening measures of the second strain from the same gigue, 29.

9. Example 4.8 d'Anglebert: "Gigue” from Pièces de Clavecin, (1689), 32.

10. Example 4.9 Bach: "Gique" from the Overture in the French Style, 34.

11. Example 4.10 Bach: "Gique” from English Suite No. 5, 35.

12. Example 4.11 Elisabeth Jacquet de La Guerre (1665-1729): "Prelude" from Suite in $G$ minor, 37.

13. Example 4.12 Froberger: Toccata No. 22 in C major, 38.

14. Example 4.13 Bach: "Praeludium” from Partita No. 1, 39.

15. Example 4.14 Bach: "Gavotte II” from English Suite No. 6, 40.

16. Example 4.15 Bach: "Bourrée I" from English Suite No. 1, 42.

17. Example 4.16 Bach: "Menuet I" from English Suite No. 4, 43. 
18. Example 4.17 François Couperin: "Chaconne a deux tems" from Ordre No. 3, "La Favorite," 45.

19. Example 4.18 Bach: "Passepied" from the Overture in the French Style, 46.

20. Example 4.19 Le Roux: "Passepied" from Suite in D minor, 47.

21. Example 4.20 Purcell: "Rigadoon" from the second part of Musick's Hand-Maid, 48.

22. Example 4.21 François Couperin: "Rigaudon” from Ordre No. 2, 48.

23. Example 4.22 François Couperin: "Rondeau" from Ordre No. 6, "Les Baricades Mistérieuses," 50.

24. Example 5.1 Bauyn manuscript: detail of a piece by Louis Couperin, showing both conventional and free notation, 53 .

25. Example 5.2 La Guerre: First and Second "Rigadouns" from Suite in D minor in Pièces de Clavecin (1707), 54.

26. Example 5.3 Chambonnières: "Pavane L'entretien des Diex" from Pièces de Clavecin, Book I, 56.

27. Example 5.4 d'Anglebert: "Tombeau de Mr. de Chambonnières" appended to his Suite in D major, 57.

28. Example 5.5 Chambonnières: "Sarabande Jeunes Zephirs" from Pièces de clavessin livre second (1670), 58.

29. Example 5.6 Clérambault: "Gigue" from Suite in C minor in Pièces de Clavecin, Book I (1704), 60.

30. Example 5.7 Clérambault: "Gigue" from Suite in C major in Pièces de Clavecin, Book I (1704), 60.

31. Example 5.8 Rameau: "L’Egyptienne” from Nouvelles Suites de Pièces de Clavecin, 64.

32. Example 5.9 François Couperin: "Les Barricades Mistérieuses” from Ordre No. 6, 66.

33. Example 5.10 François Couperin: "Le Tic-Toc-Choc" from Ordre No. 18, 67.

34. Example 5.11 François Couperin: "Les Ombres Errantes” from Ordre No. 25, 68. 
35. Example 5.12 François Couperin: "La Muse Naissante" from Les Petits Âges, 70.

36. Example 5.13 François Couperin: “L’Enfantine,” 70.

37. Example 5.14 François Couperin: "L'Adolescente," 70.

38. Example 5.15 François Couperin: "Les Délices," 71.

39. Example 7.1 A page from the manuscript presented by Froberger to Ferdinand III (1608-1657), 83.

40. Example 7.2 Froberger: "Gigue" appended to the end of Suite No. 2, 84.

41. Example 7.3 Froberger: "Allemande" and "Courante" from Suite No. 22 in E minor, 85 .

42. Example 7.4 Froberger: "Allemande" from Suite No. 16 in G major, 86.

43. Example 7.5 Fischer: "Praeludium Harpeggiato" from the Clio Suite, 90.

44. Example 7.6 Fischer: "Menuet I" and "Menuet II" from Calliope Suite, 91.

45. Example 7.7 Kuhnau: "Gavotte” from Clavier Übung II, Suite No. 7, 94.

46. Example 7.8 Handel: "Allemande" from Suite in B-flat major from Klavierbuch aus der Jugendzeit, 96.

47. Example 7.9 Handel: "Air" from the final movement of Suite No. 5, 97.

48. Example 7.10 Bach: "Prelude" from English Suite No. 1 followed by the "Gigue" from Le Roux's A major Suite, 100.

49. Example 7.11 Bach: "Allemande" from English Suite No. 3, 101.

50. Example 7.12 Bach: "Courante” from French Suite No. 3, 102.

51. Example 7.13 Bach: "Sarabande" and ornamented "Double" from English Suite No. 6, 103.

52. Example 7.14 "Polonaise" from Bach's French Suite No. 6 and mm. 9-12 of Chopin's Polonaise in B-flat major (posthumous), 104.

53. Example 7.15 Bach: Opening of the first and second sections of the "Gique" from English Suite No. 1, 105.

54. Example 7.16 Bach: "Gique" from Partita No. 1, 106. 


\title{
Index of Names and Dates
}

\author{
Alighieri, Dante (1265-1321) \\ d'Anglebert, Jean-Henri (1629-1691) \\ Arbeau, Thoinot (1520-1595) \\ Bach, Johann Sebastian (1685-1750) \\ Banister, John (1630-1679) \\ Barre, Michel de La (1675-1745) \\ Beauchamp, Pierre (1631-1705) \\ Blow, John (1649-1708) \\ Böhm, Georg (1661-1733) \\ Bull, John (1562-1628) \\ Bustijn, Pieter (1649-1729) \\ Buttstett, Johann Heinrich (1666-1727) \\ Buxtehude, Dieterich (1637-1707) \\ Byrd, William (1540-1623) \\ Cervantes, Miguel de (1547-1616) \\ Chambonnières, Jacques Champion de (1601-1672) \\ Charles II (1630-1685) \\ Chopin, Frederic (1810-1849) \\ Clarke, Jeremiah (1673/4-1707) \\ Clérambault, Nicolas (1676-1749) \\ Cotgrave, Randle (died 1634?) \\ Couperin, François (1668-1733) \\ Couperin, Louis (1626-1661) \\ Dandrieu, Jean-François (1682-1738) \\ Daquin, Louis-Claude (1692-1772) \\ Debussy, Claude (1862-1918) \\ Dieupart, François (Charles) (1670-1740) \\ Draghi, Giovanni Battista (1640-1708) \\ Ebner, Wolfgang (1612-1665) \\ Ferdinand III (1608-1657) \\ Fischer, Johann Caspar Ferdinand (1670-1746) \\ Flor, Christian (1626-1697) \\ Frescobaldi, Girolamo (1583-1643) \\ Froberger, Johann Jakob (1616-1667) \\ Fux, Johann Joseph (1660-1741) \\ Gallois, Sieur Pierre Le (fl. 1672-1680) \\ Gautier, Denis (1597-1672) \\ Gautier, Jacques (fl. 1625-40) \\ Gibbons, Christopher (1615-1676) \\ Gregory, William (1624-1691) \\ Guerre, Elisabeth Jacquet de La (1665-1729) \\ Handel, George Frideric (1685-1759)
}


Hardel, Jacques (1643-1678)

Jonson, Ben (1572/3-1637)

Kindermann, Johann Erasmus (1616-1665)

Krieger, Johann (1651-1735)

Kuhnau, Johann (1660-1722)

Lawes, William (1602-1645)

Lebègue, Nicolas-Antoine (1631-1702)

Leclair, Jean-Marie (1697-1764)

Leopold of Cöthen (1694-1728)

Locke, Matthew (1622-1677)

Louis XIV (1638-1715)

Lübeck, Vincent (1654-1740)

Lully, Jean-Baptiste (1632-1687)

Mace, Thomas (1612-1706)

Marchand, Louis (1669-1732)

Mattheson, Johann (1681-1764)

Mondonville, Jean-Joseph Cassanéa de (1711-1772)

Muffat, Georg (1653-1704)

Muffat, Gottlieb (1690-1770)

Murschhauser, Franz Xaver (1663-1739)

North, Roger (1651-1734)

Pachelbel, Johann (1653-1706)

Pasquini, Bernardo (1637-1710)

Pezel, Johann Christoph (1639-1694)

Philip II of Spain (1527-1598)

Philips, Peter (1560-1633)

Playford, John (1623-1686)

Poglietti, Alessandro (? -1683)

Praetorius, Michael (1571-1621)

Purcell, Henry (1659-1695)

Quevedo, Francisco Gómez de (1580-1645)

Rameau, Jean-Philippe (1683-1764)

Rameau, Pierre (1674-1748)

Ravel, Maurice (1875-1937)

Reincken, Johann Adam (1623-1722)

Reusner, Esaias (1636-1679)

Richter, Ferdinand Tobias (1649-1711)

Ritter, Christian (1645-1725)

Rogers, Benjamin (1614-1698)

Rousseau, Jean-Jacques (1712-1778)

Roux, Gaspard Le (1660-1706)

Scarlatti, Domenico (1685-1757)

Schultheiss, Benedict (1653-1693)

Shakespeare, William (1564-1616)

Techelmann, Franz Mathias (1649-1714)

Telemann, Georg Philipp (1681-1767) 
Vega, Lope de (1562-1635)

Vivaldi, Antonio (1678-1741)

Weckmann, Matthias (1619-1674)

Werckmeister, Andreas (1645-1706)

Witte, Christian Friedrich (1660-1716)

Zachow, Friedrich Wilhelm (1663-1712) 


\section{SELECTED BIBLIOGRAPHY}

\section{Dissertations and Theses}

Bailey, C. “English Keyboard Music, c. 1625-1680.” PhD diss., Duke University, 1992.

Brown, B. “The Harpsichord Music of Handel’s Younger English Contemporaries, 17101760: A Reassessment.” PhD diss., Victoria University of Manchester, 1966.

Fuller, D. “Eighteenth-Century French Harpsichord Music.” PhD diss., Harvard, 1965.

Gould, A. "The Keyboard Variation Suite and Suite Variation in the Seventeenth and Eighteenth Centuries.” MM thesis, Indiana University, 1951.

Hibberd, L. “The Early Keyboard Prelude.” PhD diss., Harvard, 1940.

Kitchen, J. “Harpsichord Music in Seventeenth-Century France.” PhD diss., Cambridge, 1979.

Klakowich, R. "Keyboard Sources in Mid Seventeenth-Century England and the French Aspect of English Keyboard Music.” PhD diss., Buffalo, 1985.

Maas, M. “Seventeenth-Century English Keyboard Music.” PhD diss., Yale, 1968.

Martin, M. “French Harpsichord Music: 1687-1713.” PhD diss., University of California, Los Angeles, 1991.

Miner, C. "A Comparative Study of English, French, and German Keyboard Suites of The Sixteenth, Seventeenth, and Eighteenth Centuries.” MM thesis, University of South Dakota, 1968.

Park, S. "The Seventeenth-Century Keyboard Suite in South Germany and Austria." PhD diss., Bryn Mawr College, 1980. 
Schott, H. "A Critical Edition of the Works of J. J. Froberger." PhD diss., University of Oxford, 1977.

Somer, A. "The Keyboard Music of Johann Jakob Froberger." PhD diss., University of Michigan, 1962.

Upton, H. "The French Keyboard Suite from Rameau to Honegger." MM thesis, University of California, Santa Barbara, 1973. 


\section{$\underline{\text { Articles from Periodicals and Journals }}$}

Abraham, G. “Handel's Clavier Music,” Music and Letters 16 (1935).

Annibaldi, C. “Froberger in Rome: From Frescobaldi’s Craftsmanship to Kircher's Compositional Secrets," Current Musicology 58 (1995).

Apel, W. “Early German Keyboard Music,” Musical Quarterly, April (1937).

Bailey, C. "William Ellis and the Transmission of Continental Keyboard Music in Restoration England,” The Journal of Musicological Research 20 (2001).

Bates, C. "French Harpsichord Music in the First Decade of the Eighteenth Century," Early Music 17 (1989).

Best, T. “Handel's Keyboard Music,” Musical Times 112 (1971).

Cooper, B. "The Keyboard Suite in England before the Restoration," Music \& Letters 53 (1972).

Dart, T. “New Sources of Virginal Music,” Music \& Letters 35 (1954).

. “On Couperin’s Harpsichord Music,” Musical Times 110 (1969).

Dürr, A. "The Historical Background of the Composition of J. S. Bach's Clavier Suites," Bach 16, No. 1 (1985).

Ferguson, H. "Purcell's Harpsichord Music," Proceedings of the Royal Musical Association 91 (1964-1965).

Hendrie, G. "Some Reflections on the Keyboard Music of Jean-Philippe Rameau (16831764)," Studies in Music [Australia] 22, (1988).

Koster, J. “The Harpsichord Culture in Bach's Environs," Bach Perspectives IV: The Music of J. S. Bach: Analysis and Interpretation (1999), ed. by David Schulenberg. 
Leonhart, G. “Johann Jakob Froberger and His Music,” L’Organo 6 (1968).

Louwenaari-Lueck, K. “The Sequence of Sarabande and Air in Bach's Keyboard Partitas,” Bach Vol. 23, No. 1 (1992).

Parker, M. "Some Speculations on the French Keyboard Suites of the Seventeenth and Early-Eighteenth Centuries," International Review of the Aesthetics and Sociology of Music Vol. 7, No. 2 (1976).

Rasch, R. "The Travels of Johann Jacob Froberger 1649-1650," The Keyboard in Baroque Europe (2003), ed. by Christopher Hogwood.

Schulenberg, D. "Composition and Improvisation in the School of J. S. Bach," In Bach Perspectives I (1995), ed. by Russell Stinson. 


\section{$\underline{\text { Books }}$}

Apel, W. Masters of the Keyboard. Cambridge: Harvard University Press, 1947. . Early European Keyboard Music. Stuttgart: Steiner, 1989.

. The History of Keyboard Music to 1700. Trans. by H. Tischler. Bloomington: Indiana University Press, 1972.

Beaussant, P. François Couperin. Trans. by A. Land. Portland: Amadeus Press, 1990.

Bedbrook, G. Keyboard Music from the Middle Ages to the Beginnings of the Baroque. London: Macmillan \& Co, 1949.

Borren, C. The Sources of Keyboard Music in England. Trans. by J. Matthew. Westport: Greenwood, 1970.

Boyd, M. Bach. New York: Vintage Books, 1983.

Caldwell, J. English Keyboard Music Before the Nineteenth Century. New York: Dover, 1986.

Cooper, B. English Solo Keyboard Music of the Middle and Late Baroque. New York: Garland, 1990.

Cortot, A. French Piano Music. London: H. Milford, 1932.

David, H. and A. Mendel. The New Bach Reader: A Life of J. S. Bach in Letters and Documents. Rev. and enlarged by Christoph Wolff. New York, 1998.

Ferguson, D. Piano Music of Six Great Composers. New York: Prentice-Hall, 1947.

Ferguson, H. Keyboard Interpretation from the Fourteenth to the Nineteenth Century: An Introduction. London 1975, $2^{\text {nd }}$ revised ed. 1987.

Fillmore, J. Pianoforte Music: Its History. Boston: Longwood, 1978.

Fuller-Maitland, J. The Keyboard Suites of J. S. Bach. London: Oxford, 1925. 
Georgii, W. Keyboard Music of the Baroque and Rococo. Köln: Arno Volk, 1960.

Gillespie, J. Five Centuries of Keyboard Music. New York: Dover Publications Inc., 1965.

Gordon, S. A History of Keyboard Literature: Music for the Piano and Its Forerunners. New York: Schirmer Books, 1996.

Hamilton, C. Piano Music. Boston: Oliver Ditson Co., 1925.

Harley, J. British Harpsichord Music. 2 Vols. Aldershot, 1992-94.

Hutcheson, E. The Literature of the Piano. $2^{\text {nd }}$ Ed. New York: Alfred A. Knopf, 1949.

Kenyon, M. Harpsichord Music. London: Cassell \& Co., Ltd., 1949.

Kirby, F. E. A Short History of Keyboard Music. New York: The Free Press, 1966. - Music for Piano: A Short History. Portland, Oregon: Amadeus Press, 1995.

Krehbiel, H. The Pianoforte and Its Music. New York: Scribners, 1910.

Lang, P. George Frideric Handel. Mineola, New York: Dover Publications, Inc. 1966.

Ledbetter, D. Harpsichord and Lute Music in Seventeenth-Century France. London: Macmillan, 1987.

Little, M., and N. Jenne. Dance and the Music of J. S. Bach. Bloomington: Indiana University Press, 1991.

Lockwood, A. Notes on the Literature of the Piano. Ann Arbor: University of Michigan Press, 1940.

Marshall, R., Ed. Eighteenth-Century Keyboard Music. New York: Schirmer, 1994. . The Music of J. S. Bach: The Sources, the Style, the Significance. New York, 1989.

Matthews, D. Keyboard Music. New York: Praeger, 1972. 
Mellers, W. François Couperin and the French Classical Tradition. London and Boston: Faber \& Faber, 1987.

Russell, R. The Harpsichord and Clavichord: An Introductory Study. New York, 1965.

Scheibert, B. Jean-Henri d'Anglebert and the Seventeenth-Century Clavecin School. Bloomington: Indiana University Press, 1986.

Schulenberg, D. The Keyboard Music of J. S. Bach. New York: Schirmer, 1992.

Schweitzer, A. J. S. Bach. Trans. by E. Newman. New York: Dover Publications, Inc. 1966.

Silbiger, A. Ed. Keyboard Music Before 1700. New York: Routledge, 2004.

Spitta, P. J. S. Bach. 3 Vols. Leipzig, 1873-1880. English trans., reprint. New York, 1952.

Walker, E. A History of Music in England, $3^{\text {rd }}$ Ed. rev. by J. A. Westrup. London: Oxford University Press, 1952.

Weiser, B. Keyboard Music. Dubuque: Brown, 1971.

Weitzmann, C. F. A History of Pianoforte Playing and Pianoforte Literature. Trans. by Theodore Baker. New York: G. Schirmer, 1897.

Westerby, H. The History of Pianoforte Music. London: Kegan, Paul, Trench, Trubner, \& Co., Ltd., 1924.

Wier, A. The Piano: Its History, Makers, Players, and Music. New York: Longmans, Green, 1941.

Wolff, C. J. S. Bach: Essays on His Life and Music. Massachusetts: Cambridge, 1991. . Johann Sebastian Bach: The Learned Musician. New York: W. W. Norton \& Company, 2000. 


\section{Dictionaries, Encyclopedias, and Reference Guides}

Bailey, C. Seventeenth-Century British Keyboard Sources. Michigan: Warren, 2003.

Breig, W. "Composition as Arrangement and adaptation," The Cambridge Companion to Bach. Ed. John Butt. Cambridge, 1997.

Brookes, V. British Keyboard Music to c. 1660: Sources and Thematic Index. Oxford, 1996.

Buelow, G. "Froberger," The New Grove North European Baroque Masters. New York, 1985.

Caldwell, J. “Keyboard Music: 1630-1700,” The New Oxford History of Music, Vol. 6. Ed. Gerald Abraham. Oxford, 1986.

Cooper, B. "Keyboard Music," The Blackwell History of Music in Britain, Vol. 3. Ed. Ian Spink. Oxford, 1992.

Fallows-Hammond, P. 300 Years at the Keyboard: A Piano Sourcebook from Bach to the Moderns. Berkeley: Ross, 1984.

Friskin, J. and I. Freundlich. Music for the Piano: A Handbook of Concert and Teaching Material from 1580 to 1952. New York: Dover, 1974.

Fuszek, R. Piano Music in Collections: An Index. Indiana: Harmonie Press, 1982.

Gustafson, B. and D. Fuller. A Catalog of French Harpsichord Music, 1699-1780. Oxford: Clarendon, 1990.

Hinson, M. Guide to the Pianist's Repertoire. $2^{\text {nd }}$ Ed. Bloomington: Indiana University Press, 1987.

. The Pianist's Reference Guide: A Bibliographical Survey. Los Angeles: Alfred, 1987. 
Kennedy, M. Ed. The Oxford Dictionary of Music. New York: Oxford University Press, Inc., 2006.

Palmieri, R. Piano Information Guide. New York: Garland, 1989.

Parrish, C. and J. Ohl. Ed. Masterpieces of Music before 1750: An Anthology of Musical Examples from Gregorian Chant to J. S. Bach. New York: W. W. Norton \& Company, Inc., 1951.

Rezits, J. The Pianist’s Resource Guide. Illinois: Pallma, Park Ridge, 1974. 


\section{Webliography}

Caldwell, J. "Sources of Keyboard Music to 1660," The New Grove Dictionary of Music and Musicians. Ed. by L. Macy. (Accessed 11/14/07) http://www.newgrovemusic.com.

. "Sources of Keyboard Music to c.1750," The New Grove Dictionary of Music and Musicians. Ed. by L. Macy. (Accessed 11/15/07) http://www.newgrovemusic.com.

Cole, M. "Rondo," The New Grove Dictionary of Music and Musicians. Ed. by L. Macy. (Accessed 1/8/10) http://www.newgrovemusic.com.

Fuller, D. "Suite," The New Grove Dictionary of Music and Musicians. Ed. by L. Macy. (Accessed 11/14/07) http://www.newgrovemusic.com.

Heartz, D. and P. Rader. "Branle," The New Grove Dictionary of Music and Musicians. Ed. by L. Macy. (Accessed 1/5/10) http://www.newgrovemusic.com.

Hudson, R. "Sarabande," The New Grove Dictionary of Music and Musicians. Ed. by L. Macy. (Accessed 3/21/09) http://www.newgrovemusic.com.

IMSLP [International Music Score Library Project]/ Petrucci Music Library. (Accessed 4/3/09) http://imslp.org/wiki/Main_Page.

Ledbetter, D. "Prelude," The New Grove Dictionary of Music and Musicians. Ed. by L. Macy. (Accessed 3/21/09) http://www.newgrovemusic.com.

Little, M. "Bourrée," The New Grove Dictionary of Music and Musicians. Ed. by L. Macy. (Accessed 1/6/10) http://www.newgrovemusic.com. . "Gavotte." The New Grove Dictionary of Music and Musicians. Ed. by L. Macy. (Accessed 1/4/10) http://www.newgrovemusic.com. 
. "Gigue," The New Grove Dictionary of Music and Musicians. Ed. by L. Macy.

(Accessed 3/21/09) http://www.newgrovemusic.com.

. "Minuet," The New Grove Dictionary of Music and Musicians. Ed. by L.

Macy. (Accessed 1/6/10) http://www.newgrovemusic.com.

. "Passepied," The New Grove Dictionary of Music and Musicians. Ed. by L.

Macy. (Accessed 1/8/10) http://www.newgrovemusic.com.

. "Rigaudon," The New Grove Dictionary of Music and Musicians. Ed. by L.

Macy. (Accessed 1/8/10) http://www.newgrovemusic.com.

. and S. Cusick. "Allemande," The New Grove Dictionary of Music and

Musicians. Ed. by L. Macy. (Accessed 3/21/09) http://www.newgrovemusic.com.

. and S. Cusick. "Courante," The New Grove Dictionary of Music and Musicians.

Ed. by L. Macy. (Accessed 3/22/09) http://www.newgrovemusic.com.

OMI www.omifacsimilies.com. (Accessed 8/18/09).

Schott, H. "Froberger," The New Grove Dictionary of Music and Musicians. Ed. by L.

Macy. (Accessed 1/7/10) http://www.newgrovemusic.com.

Silbiger, A. "Chaconne," The New Grove Dictionary of Music and Musicians. Ed. by L. Macy. (Accessed 1/7/10) http://www.newgrovemusic.com. 